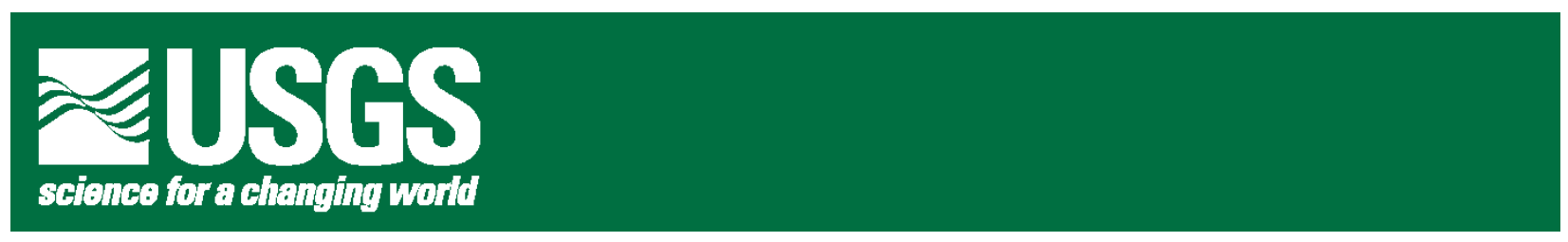

\title{
A Debris Avalanche at Forest Falls, San Bernardino County, California, July 11, 1999
}

By Douglas M. Morton ${ }^{1}$ and Rachel M. Hauser ${ }^{1}$

Open-File Report 01-146

Version 1.0

2001

Available online at http://geopubs.wr.usgs.gov/open-file/of01-146/

This report is preliminary and has not been reviewed for conformity with U.S. Geological Survey editorial standards. Any use of trade, product, or firm names is for descriptive purposes only and does not imply endorsement by the U.S. Government.

\section{U.S. DEPARTMENT OF THE INTERIOR U.S. GEOLOGICAL SURVEY}

${ }^{1}$ U.S. Geological Survey, Department of Earth Sciences, University of California, Riverside, CA 92521 


\section{Contents}

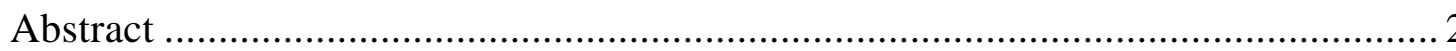

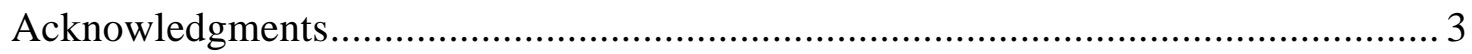

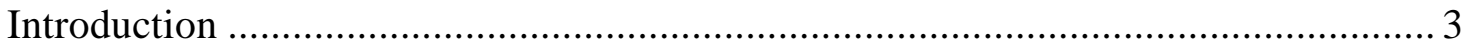

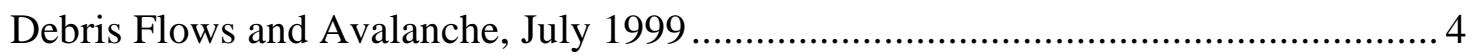

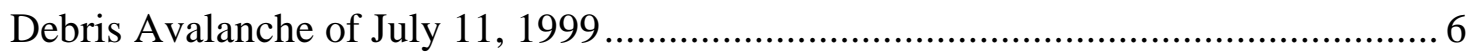

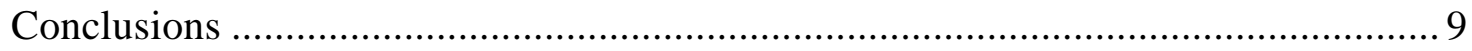

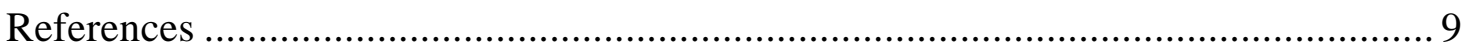

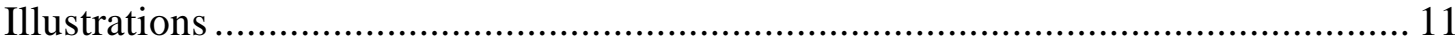

\section{Abstract}

The community of Forest Falls, California, is frequently subject to relatively slow moving debris flows. Some 11 debris flow events that were destructive to property have been recorded between 1955 and 1998. On July 11 and 13, 1999, debris flows again occurred, produced by high-intensity, short-duration monsoon rains. Unlike previous debris flow events, the July 11 rainfall generated a high-velocity debris avalanche in Snow Creek, one of the several creeks crossing the composite, debris flow dominated, alluvial fan on which Forest Falls is located. This debris avalanche overshot the bank of the active debris flow channel of Snow Creek, destroying property in the near vicinity and taking a life. The minimum velocity of this avalanche is calculated to have been in the range of 40 to 55 miles per hour. Impact from high-velocity boulders removed trees where the avalanche overshot the channel bank. Further down the fan, the rapidly moving debris fragmented the outer parts of the upslope side of large pine trees and embedded rock fragments into the tree trunks. Unlike the characteristic deposits formed by debris flows, the avalanche spread out down-slope and left no deposit suggestive of a debris avalanche. This summer monsoon-generated debris avalanche is apparently the first recorded for Forest Falls. The best indications of past debris avalanches may be the degree of permanent scars produced by extensive abrasion and splintering of the outer parts of pine trees that were in the path of an avalanche. 


\section{Acknowledgments}

We appreciate the help and interaction in the field with Wes Reeder, Bob Fleming, Rick Everert, Henry Jones, Anne Kennedy, Rich Minnich, Natalie Morton, Gary Patt, and Eric Riggs. Russ Campbell, Wes Reeder and Cynthia Diamadi provided critical reviews. Wes Reeder kindly provided photographs of the 1997 and some of the 1999 debris flows. Uncredited photographs are by the authors.

\section{Introduction}

Forest Falls is an idyllic mountain community located in the southern San Bernardino Mountains of southern California (Figure 1), The community is located on a series of coalesced fans composed almost entirely of debris flow deposits (e.g., Reeder, 1993, p. 59). The coalesced debris-flow fans are located along the base of the north side of east southeast trending Yucaipa Ridge that rises abruptly to heights of over 3,000 feet above Forest Falls. Yucaipa Ridge is located between the Mill Creek and San Bernardino strands of the San Andreas fault zone; these strands have been commonly referred to as the north and south branches of the San Andreas fault zone. The ridge is underlain by a variety of thoroughly fractured gneissic rock and subordinate leuco-granitic rock. In places, Yucaipa Ridge has a smooth rounded crest; in other places it is extremely sharp and rocky. Above Forest Falls the ridge crest is rounded and is covered with relatively fine-grained decomposed rock. Numerous debris chutes coalesce on the ridge side to form rocky debris-filled canyon floors along the lower part of the ridge side (Figure 2). The debrisfilled canyon floors debauch from the mountain front onto the composite fan where Forest Falls is located (Figure 3).

All the active channels visited on the fans are bounded by debris flow levees. Some of these levees are quite substantial, products of numerous debris flows and attain widths of several hundred feet (Figure 4). The Snow Creek levee is more than 250 years in age based on the age of pine trees on the levee in the upper part of the fan. Commonly perched along the lip of a large levee is a. narrow sharp-topped debris flow ridge. These perched narrow sharp-topped debris flow ridge deposits are the product of overflow from a single debris flow event or as clasts were pushed away from the front of moving debris flows and over the channel bank Figure 5).

The surface of the coalesced fans is covered by morphologic remnants of past debris flows. Debris flow remnants include segments of abandoned debris flow channels; debris flow levees; and steep-fronted, rocky, debris flow snouts (Figures 6, 7, 8, 9, and 10). The debris flow deposits include many large (5-8 ft) boulders scattered throughout the length of the fan. In addition to boulders transported by debris flows, near the base of Yucaipa Ridge 
are boulders resulting from seismically generated rock falls (Barrows, 1993; Reeder, 1993).

Since 1955, newspaper and other accounts record 11 significant debris flow events at Forest Falls prior to 1999. These debris flows resulted in damage to houses and vehicles (Figures 11, 12, 13, and 14). An Interoffice Memo, San Bernardino County, indicates significant debris flow occurrences in the Forest Falls area prior to 1999 were August 24, 1955; July 30, 1958; August 24, 1961; November 26 and 27, 1965; July 17 and 18, 1984; August 11, 1989; and September 4, 1997. The dates of the recorded debris flows indicate all but the November 1989 events formed in response to short-duration, high-intensity summer monsoon rains. The November events were probably the product of a very localized, intense convection cell, as nearby areas received little if any rainfall during this period.

Descriptions of the historic debris flow events indicate they were relatively slow moving, laminar-flowing debris flows. Most velocity estimates by local observers are in the range of a few to 10 miles per hour. The morphology of prehistoric debris flows likewise indicates relatively slow moving flows. In the proximal part of some of the fans are remnants of non-channelized debris flows that flowed around bedrock projections at angles approaching $90^{\circ}$; only a slow-moving debris flow could make such a sharp turn out of a confining channel. A new aspect for the recorded debris flow activity at Forest Falls was the much greater velocity of the July 11, 1999, event in Snow Creek. This event is best described as a debris avalanche. The basic difference between the debris flows at Forest Falls and the debris avalanche is the debris flows move in a laminar fashion and the debris avalanche by turbulent flow. In debris flow the clast-supporting matrix basically acts as a binding or cushioning agent preventing clasts from high energy impact that in turn results and/or maintains lamellar flow. Thinning the matrix by adding water produces a nonebinding or a none-cushioning matrix that results in high-energy impact of clasts resulting in and/or maintaining turbulent flow. Generally where a debris flow stabilizes, muddy water seeps out of the snout of the debris flow leaving behind a muddy boulder mixture Figure 15). In a debris avalanche the higher water content generally results in a cleaner deposit, largely devoid of mud (e.g. Johnson, 1996) (Figure 16). However if a debris flow is followed by large quantities of water much of the muddy matrix of a debris flow can be removed by the water but the steep snout of the debris flow generally remains.

\section{Debris Flows and Avalanche, July 1999}

On July 11 and 13, 1999, high-intensity, short-duration monsoon rains once again spawned debris flows, and on July 11 one canyon, Snow Creek, was the site of a debris avalanche. Debris avalanches have apparently not been previously reported for the Forest Falls area. 
The debris avalanche attracted attention as it caused loss of a life and was particularly destructive to property. The San Bernardino County Assessor's Office estimated the debris avalanche resulted in about $\$ 1,170,000$ of structural damage.

Debris flows were generated in a number of channels on the north side of Yucaipa Ridge, including three channels that served as conduits for property-destructive debris flows in the eastern part of Forest Falls. Radar images of rainfall on July 11 indicate about 3 inches of rain for a 24-hour period; the most intense rainfall was from a small cell centered over the head of these three basins. Residents report a rainfall of 2.5 inches in a 30-minute period for the late afternoon of July 11. Another monsoon storm cell developed over Yucaipa Ridge on the late afternoon of July 13 producing rainfall similar to that of July 11.

An aerial survey of the Forest Falls area was conducted on July 15 to view the source and depositional areas of the debris flows of July 11 and 13. The primary purpose of the survey was to determine if there was any evidence of immediate landslide threat to Forest Falls produced by the rainfall of July 11 and 13. The other purpose was to see if there was evidence of any massive landsliding that could have mobilized debris and generated the debris flows and avalanche in the headward part of the drainages above Forest Falls. No evidence was seen of any new landslides in the headward parts of these drainages.

Based on observations made during the aerial survey, Yucaipa Ridge was subjected to extensive sheet wash and rilling on July 11 and 13. Pervasive, relatively large-scale rilling was observed along Yucaipa Ridge (Figures 17 and 18), The debris flows of July 11 and 13 and the avalanche appear to be the result of high intensity rainfall incorporating and mobilizing rilled material from ridge tops and sides. On entering the upper part of the fan, the mobilized rilled material in turn mobilized boulder debris from the canyon floor to develop the debris flows. The floors of the canyons above Forest Falls contain very large amounts of loose debris; the amount of loose debris constitutes potential source material for future debris flows and far exceeds the volume of debris deposited by the flows of July 11 and 13 (Figures 19 and 20). The largest clast transported during the July 11 avalanche is 16 feet in length and weighs approximately 70 tons (Figure 21). This clast is located where the debris avalanche shot over the bank of the debris flow channel of Snow Creek.

Well-developed, old debris flow levees exist just upstream from the point where the debris overshot the channel wall (Figure 22). Such debris flow levees are common elsewhere on the debris flow fans on which Forest Falls is located. The debris avalanche eroded the upper part of the debris flow levee where it overshot the channel. The debris flows on July 11 and 13 deposited rocky debris of varying width on existing debris flow levees especially on Rattlesnake Creek fan. The debris flows were followed by debris-laden water that appeared to be mainly confined to the pre-storm channel. 
Large, slow-moving debris flows overran the channel walls of Rattlesnake Creek spreading out over the fan and covering Valley of the Falls Drive, the road into Forest Falls, to a depth of over 6 feet and a width of several hundred feet (Figure 23). Included within the debris flows were numerous large boulders, 6 to 8 feet in length (Figures 24 and 25). The currently active debris flow channel of Rattlesnake Creek in the proximal part of the fan is large and well-developed. In the medial part of the fan, slow-moving flows blocked the active channel with debris more than 12 feet deep. A new channel was developed to the west of the blocked channel. The abandoned channel was the course of 1997 debris flows Figures 26, 27, and 28). Perched remnants of the 1999 debris flows in the abandoned channel indicate the debris flows were at heights of 6 to 8 feet above the fan surface (Figure 29)

\section{Debris Avalanche of July 11, 1999}

The velocity of the rocky debris that caused most of the structural damage and the loss of a life in Snow Creek greatly differed from the velocity of the contemporary debris flows in the adjacent canyons. The velocity of the debris flows in Rattlesnake and Rock creeks is estimated to be about 10 to 20 percent of the velocity of the Snow canyon debris. The term "debris avalanche" (Varnes, 1978) probably best characterizes the high-velocity flow of July 11 in Snow Creek and distinguishes it from the typical more slowly moving debris flows.

The debris avalanche did not develop the sort of blocky snout that characterizes the more slow moving debris flows (Figures 30 and 31). After exiting the channel the debris avalanche, unconfined by channel wall, laterally spread and thinned as it descended downfan. If the debris avalanche had been constrained within the channel, it would have perhaps developed a deposit characteristic of debris flows as its velocity decreased.

Witnesses described the debris avalanche as having three "waves" that topped the debris flow channel wall. The house where the fatality occurred was directly in the path of the first wave. One or both of the subsequent waves apparently exited the channel a short distance down channel from where the first wave exited. One house, adjacent to the channel, was struck on both sides by different waves Figure 32.

The typical slow-moving debris flows scar the up-fan side of trees, removing bark with little fragmentation of the underlying wood Figure 33. In contrast, the debris avalanche where it 'shot-over' the channel bank cut down trees in the direct path of the avalanche and abraded and splintered the up-fan side of larger trees along the margins of the avalanche and down-slope from the channel (Figures 34 and 35). Rocks were embedded in the fragmented wood of some trees. Some embedded rocks were fragmented on impact with 
the tree (Figure 36) and some wood splinters from shattered houses flew at velocities great enough to become embedded in trees (Figures 37 and 38). Trees along the margin of the avalanche were scared similar to the scars produced by debris flows Figure 39].

High-velocity flows descending a curving channel are elevated on the outside of the curve much as a bobsled rounding curves. This characteristic is termed "superelevation". The degree of superelevation is a function of the velocity of the flow, the width of the flow, and the curvature of the channel. Deposits and scars on tree trunks indicating superelevation were observed at three open curves in the debris flow channel upstream from the point where the avalanche shot-over the channel wall (Figures 40 and 41. The 'apparent' maximum superelevation observed was 11 feet. Apparent because the low side of debris deposits used in the measurement is likely produced by a later slow-moving debris flow that filled most of the channel and was at a height greater than that on the low side of the avalanche as it descended the curve.

The velocity of the debris avalanche can be calculate using the equation $v^{2}=g \times r c \times \tan$ se $/ w$, where $v=$ velocity, $g=$ gravity, $r c=$ radius of curvature, $s e=$ superelevation, and $w=$ width of flow (e.g., Costa, 1984). Measurements at these three curves indicate a velocity 40 to $55 \mathrm{mph}$ for the debris avalanche as it passed through this part of the canyon. There is obviously a high degree of uncertainty that the remnant deposits used to determine superelevation were from the same flow. Measurements of superelevation were made in Snow Creek after debris flows of July 13. The debris flows of July 13 filled much of the channel. The topographic low part of deposits used in the velocity calculations was likely produced by the flows of July 13 rather than the avalanche of July 11 . Thus the calculated velocities are minimal. Downstream from these open curves is a tighter curve that the avalanche could not negotiate; this is where the debris shot over the 8-foot high channel wall Figure 42. Calculations, based on measurements where the debris avalanche shot over the debris flow channel wall indicate the minimum velocity of the avalanche was in the range of $45-55 \mathrm{mph}$; a velocity of about $38 \mathrm{mph}$ would be required for the avalanche to have reached the top of the channel wall. The velocity of the July 11 debris avalanche was estimated by an eyewitness as 50 to $60 \mathrm{mph}$ and the duration of the flow estimated to be a few to about 45 seconds. Based on eyewitness accounts of debris flows over the past 20 years, the "normal" velocity of debris flows in the Forest Falls area is estimated at about 10 mph or less.

Eyewitnesses described the three "waves" as each reaching heights of up to 25 feet, each with duration of up to 15 seconds. A two-story house occupied by four persons was directly in the path of the first wave about 80 feet beyond the channel wall. The avalanche destroyed the house and the trees between the house and the channel. Only the battered 
concrete foundation of the house remained (Figures 43, 44, and 45), The fragmented house was transported 450 feet down the fan; three of the occupants remained within the wreckage, the fourth was carried about 550 feet further down the fan. One of the occupants in the wreckage was killed, the others severely injured.

The debris avalanche at Snow Creek eroded the debris flow levee surface where it shot over the channel bank. The fast-moving avalanche stripped vegetation and oriented flattened trees parallel to the flow direction Figures 46, 47,48, and 49), flattened automobiles Figures 50 and 51) and wreaked destruction of everything in its path for a short distance below the channel Figures 52,53, and 54). More than 100 feet beyond the channel wall, the upstream side of larger trees in the path of the avalanche were shattered and contained embedded small clasts of gneiss and granite. Further evidence of the turbulent and violent nature of the debris avalanche is an impact scar on trees that were produced by rocks thrown to heights of 6 to 8 feet above the main mass of the avalanche Figure 55). Along the spreading margins of the avalanche bark was stripped from trees to heights of eight feet above the fan surface and mud splattered an additional 10-15 feet. Also suggestive of high velocity was the wood splinter that impaled a tree trunk about 300 feet beyond the channel.

Down slope, unconfined by channel walls, the avalanche quickly spread out and its velocity greatly diminished. Structural damage likewise diminished, but was still considerable with the decrease in velocity and the spreading out of the debris (Figure 56). Down fan, elongate "islands" on the fan surface were untouched by the debris. It is not known whether the width of Snow Creek avalanche deposit was due to similar spreading out of each wave or if each wave took a slightly different path.

The high velocity of the debris avalanche appears to be due to water content greater than that of the slower-moving debris flows. In the debris flows, the matrix acts more like a cushion or binding agent; in the avalanche, the boulders are free to interact, resulting in a greater and sustained velocity (e.g., Johnson, 1996; Morton, D.M., unpub. data). Perhaps the greater water content resulted from the larger basin size, compared to the adjacent basins, funneling more water into the relatively narrow channel; or perhaps from more intense rainfall in Snow Creek compared to the adjacent basins. Unconfirmed reports give rainfall amounts of 2.5" in 30 minutes in the late afternoon of July 11 at Forest Falls.

During periods of debris flow activity at Forest Falls, Mill Creek (Figure 3) apparently has high discharge. Debris flows entering Mill Creek are almost immediately diluted by the volume of water in Mill Creek which winnows matrix from the debris flows. This results in a normal fluvial aspect for the sediment in Mill Creek (Figure 57). The large boulder clasts that were transported by suspension in the matrix of the debris flows, move down 
Mill Creek by saltation and traction that quickly round the angular, debris flow derived clasts.

\section{Conclusions}

Significant debris flow events have occurred about 11 times since the early 1950s. Based on available accounts, all these previous events were apparently relatively slow moving debris flows. Forest Falls is located on deposits recognizable as originating as this type of debris flow. The high-velocity debris avalanche, of July 11, 1999, appears to be unique. Whereas the "normal" slow-moving debris flows can be very destructive to physical property, they appear minimally life threatening. However, the high-velocity debris avalanches are potentially catastrophic events with significant life threatening hazard as well as being remarkably destructive to physical property. Unlike the characteristic morphologic features produced by debris flows, we have no criteria to identify prehistoric debris avalanche deposits in the Forest Falls area. Perhaps the presence of extensive fragmentation of tree trunks would be the most readily visible means of detecting debris avalanches and the frequency of prior debris avalanches. As a crude measure, if a resident of Forest Falls can look up a canyon mouth, they could be in the path of a future avalanche.

\section{References}

Barrows, A. G., 1993, Rockfalls and surface effects other than faulting, Landers and Big Bear earthquakes: California Geology, v. 46, p. 17-22.

Costa, J. E., 1984, Physical geomorphology of debris flows, in, Costa, J.E, and Fleisher, P.J., eds., Developments and applications of geomorphology: Springer-Verlag, Berlin Heidelberg New York Tokyo, p. 268-317.

Johnson, A.M., 1996, A model for grain flow and debris flow: U. S. Geological Survey Open-file Report 96-728.

Matti, J.C. and Morton, D. M., 1993, Paleogeographic evolution of the San Andreas fault in southern California: a reconstruction based on a new cross-fault correlation, in Powell, R.E,, Weldon, R.J., III, and Matti, J.C., eds., The San Andreas fault system: displacement, palinspastic reconstruction, and geologic evolution: Geological Society of America Memoir 178, p. 107-159.

Matti, J.C., Morton, D. M., and Cox, B.F., 1992, The San Andreas fault system in the vicinity of the Transverse Ranges Province, southern California: U.S. Geological Survey Open-file Report 92-354. 
Reeder, W.E., 1993, Seismically-induced rockfall in the Forest Falls area of the San Bernardino Mountains as a result of the Landers Earthquake sequence, in Reynolds, R.E. complier, Landers: earthquakes and aftershocks: San Bernardino County Museum Association Quarterly, p. 56-59.

Varnes, D.J., 1978, Slope movement types and processes, in Schuster, R.L., and Krizek, R.J., eds, Landslides analysis and control: Transport. Res. Board Spec. Rept. 175, Natl. Acad. Sci, Washington DC, p. 11-33. 
Figure I. Map showing regional geologic framework and location of Forest Falls. Faults modified from Matti and others (1992) and Matti and Morton (1993). Faults shown in colors are strands of the San Andreas Fault; red indicates modern traces of the

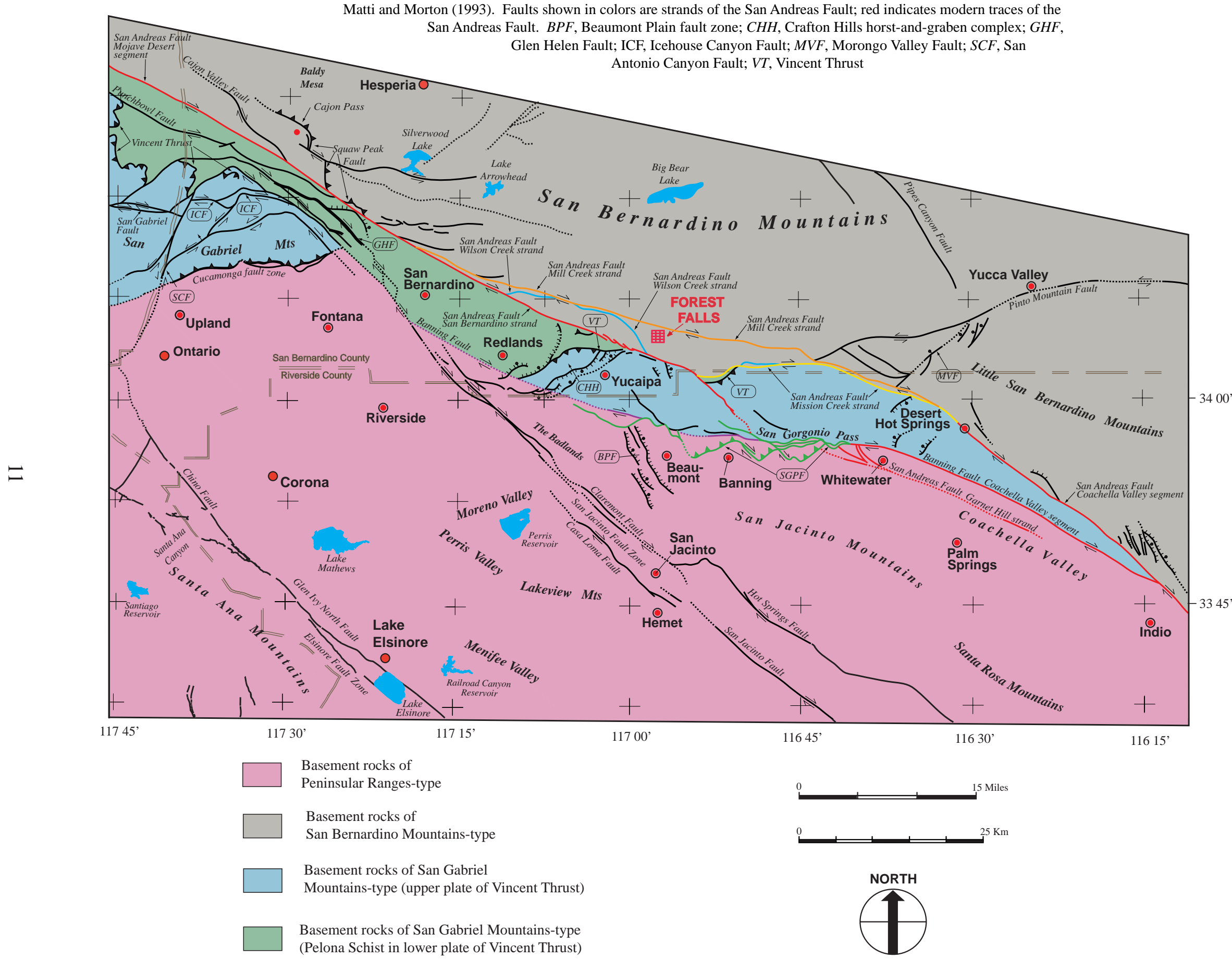




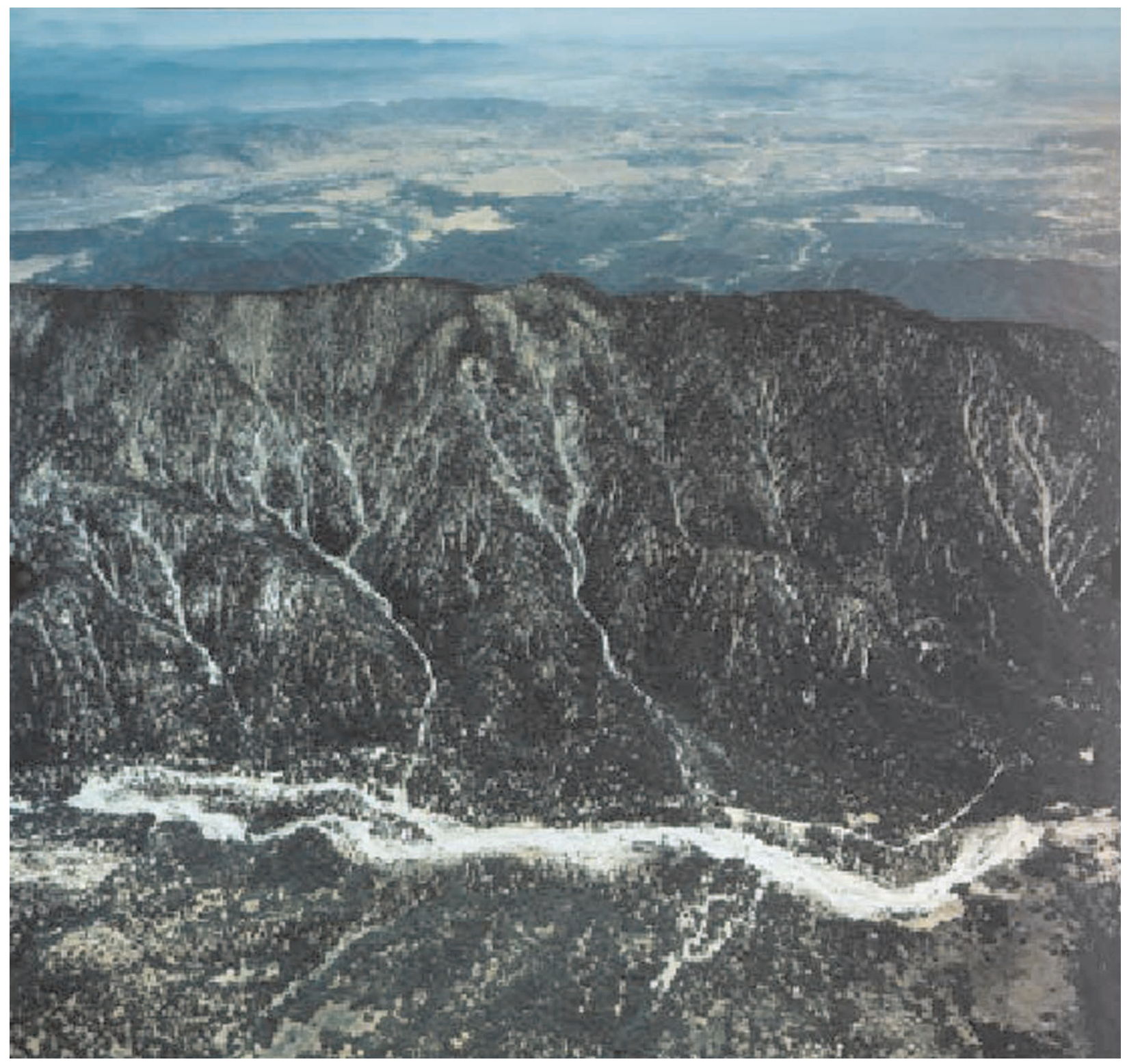

Figure 2. View looking south across Mill Creek and the south face of Yucaipa Ridge. Rock Creek is the relatively small drainage on the left side of the photograph that does not reach the summit of Yucaipa Ridge. To the right of Rock Creek is Snow Creek canyon with a broad headward drainage area. The relatively narrow elongate drainage to the right of Snow Creek is Rattlesnake Canyon. Note the bare branching channels that extend nearly to the summit of these three drainages. Photograph by I.K. Curtis. 


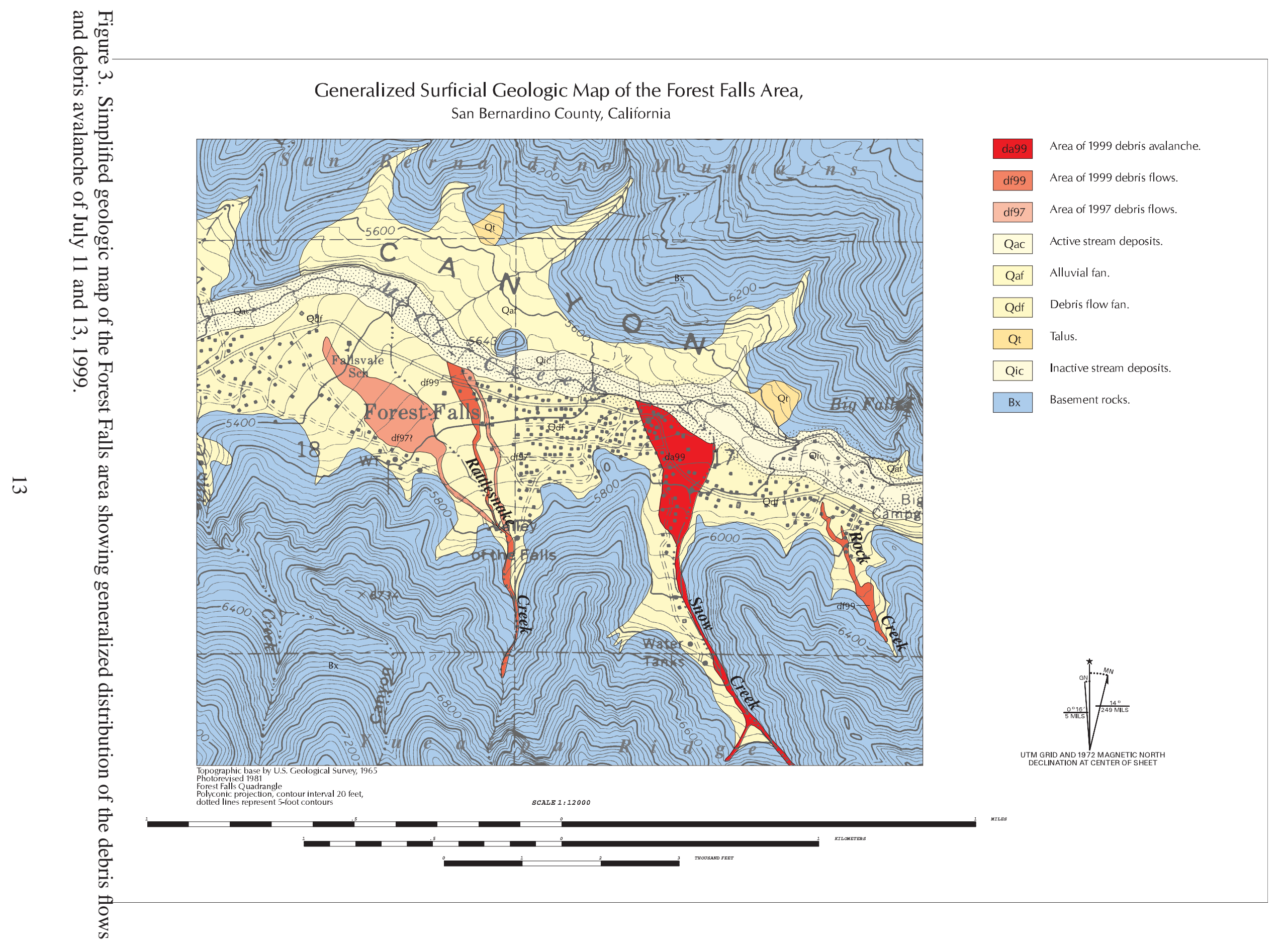




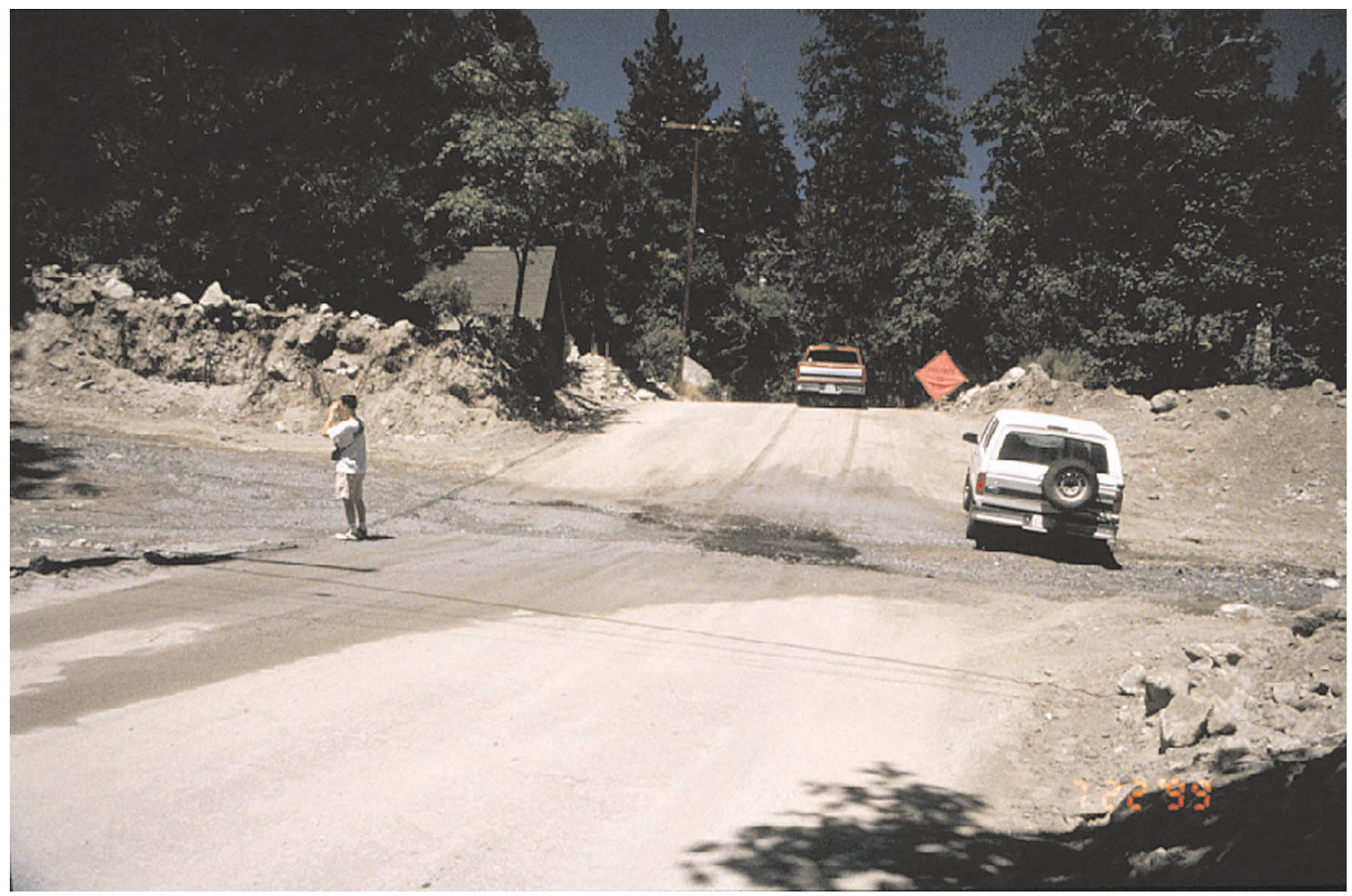

Figure 4. Broad debris flow levee on the lower part of Snow Creek fan where the Valley of Falls Road crosses Snow Creek. View is to the west. Here the levee is several hundred feet in width. Photograph was taken at the crest on the east side of the levee; the near car is at the center of the channel and the far car is on the crest of the west levee. These broad debris flow levees give rise to the rather anomalous setting of a channel occupying the crest of the topographic high. 


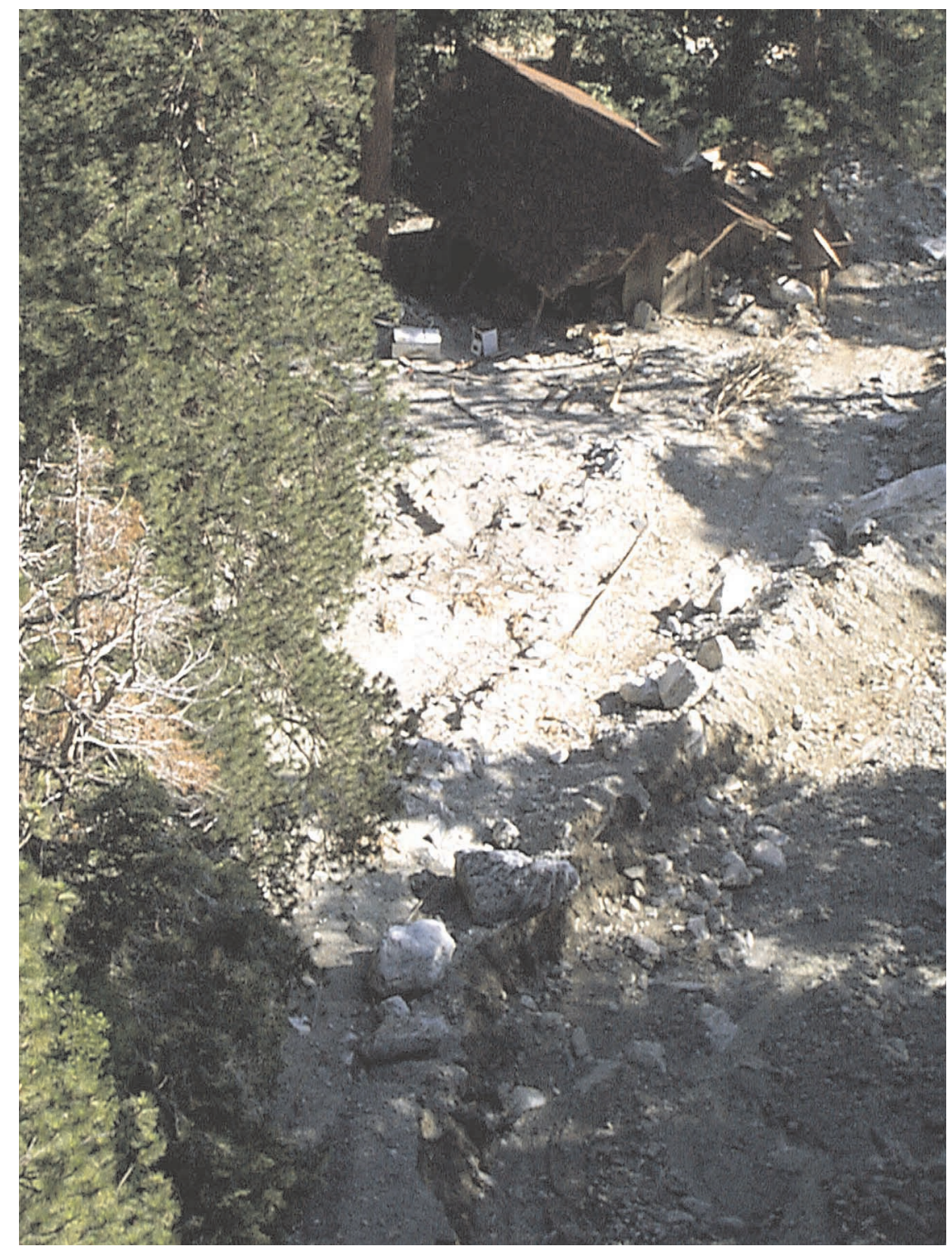

Figure 5. Medial part of Snow Creek fan. In the lower right foreground is Snow Creek debris flow channel with a newly formed, sharp-crested debris ridge. This stretch of the channel is where the debris avalanche of July 11, 1999, shot over the channel wall degrading the debris flow levee and removing vegetation. The sharp crested ridge along the channel was formed by debris flows on July 13, 1999. The house in the background was struck on the left by the $1^{\text {st }}$ debris avalanche surge and struck on the right by the $2^{\text {nd }}$ and/or $3^{\text {rd }}$ surge. Note the flattened trees oriented parallel to the $2^{\text {nd }}\left(\right.$ ?) and $3^{\text {rd }}$ debris avalanche waves. Photograph taken July 15, 1999. 


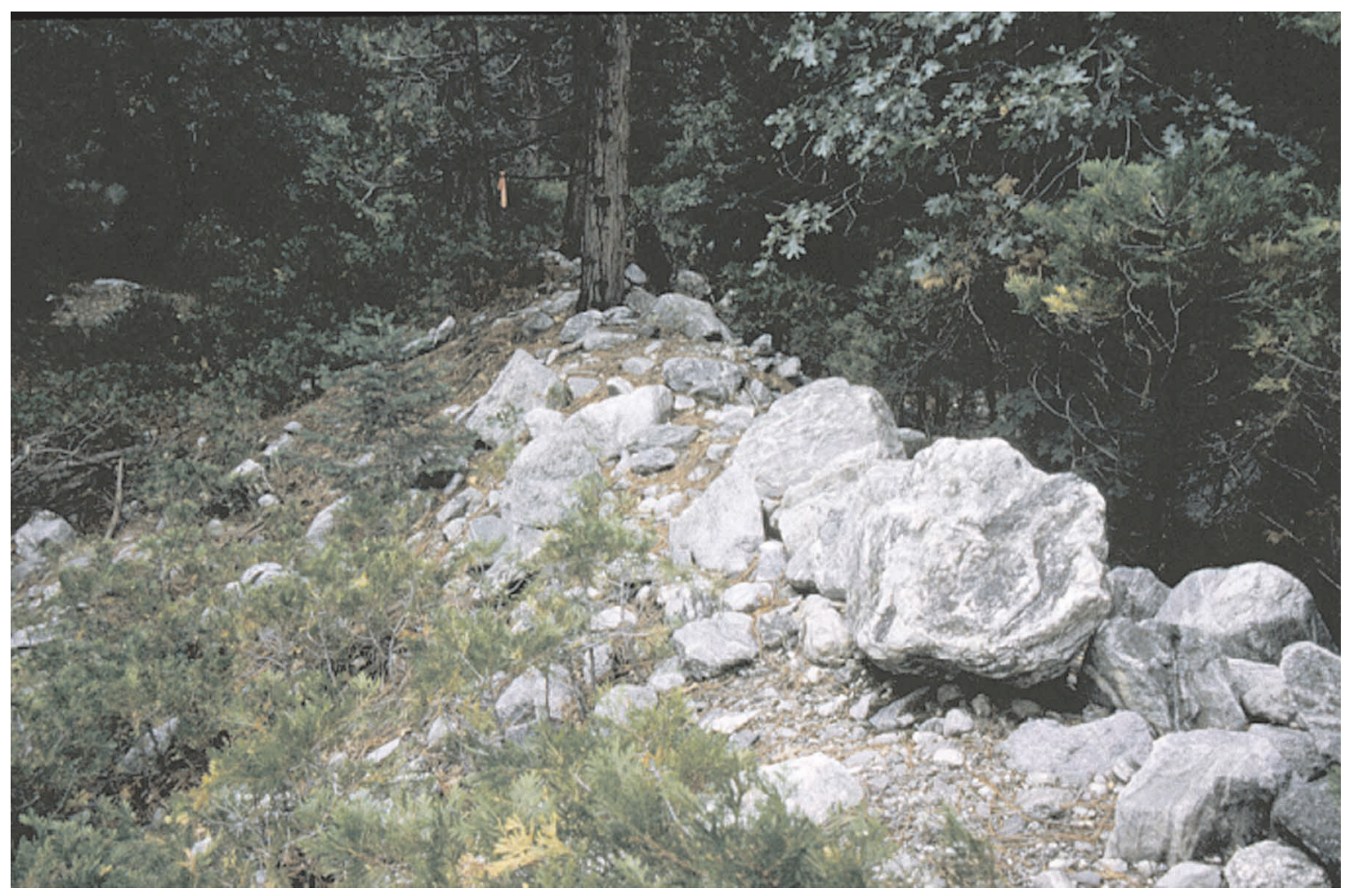

Figure 6. Sharp-crested debris flow ridge on the medial part of Rattlesnake Creek fan. The age of this ridge is over 50 years based on the size of trees growing on the crest of the ridge. 


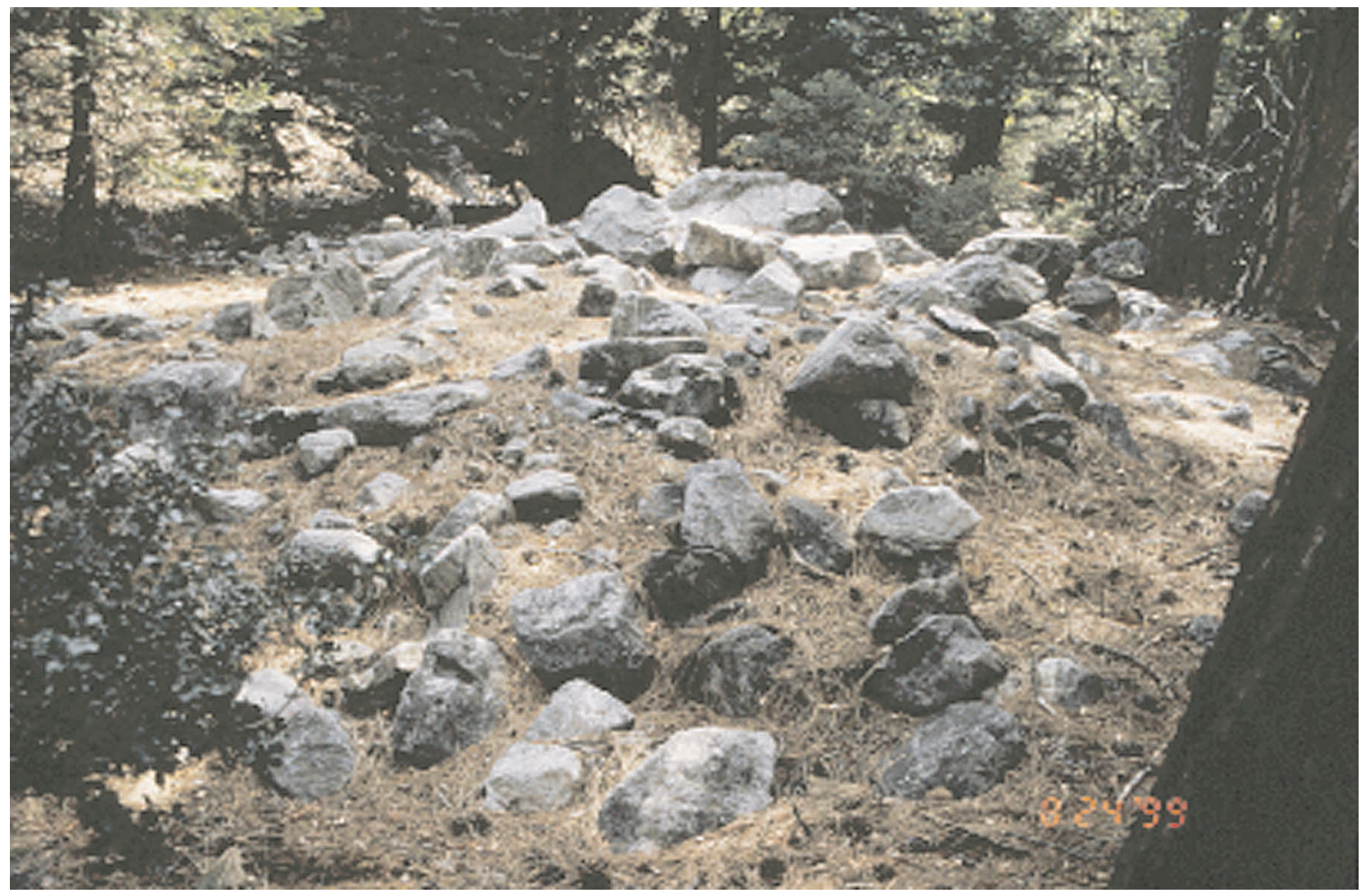

Figure 7. Rocky snout of a slow-moving debris flow on the proximal part of Snow Creek fan. This debris flow is over 250 years based on the age of trees growing on the deposit. 


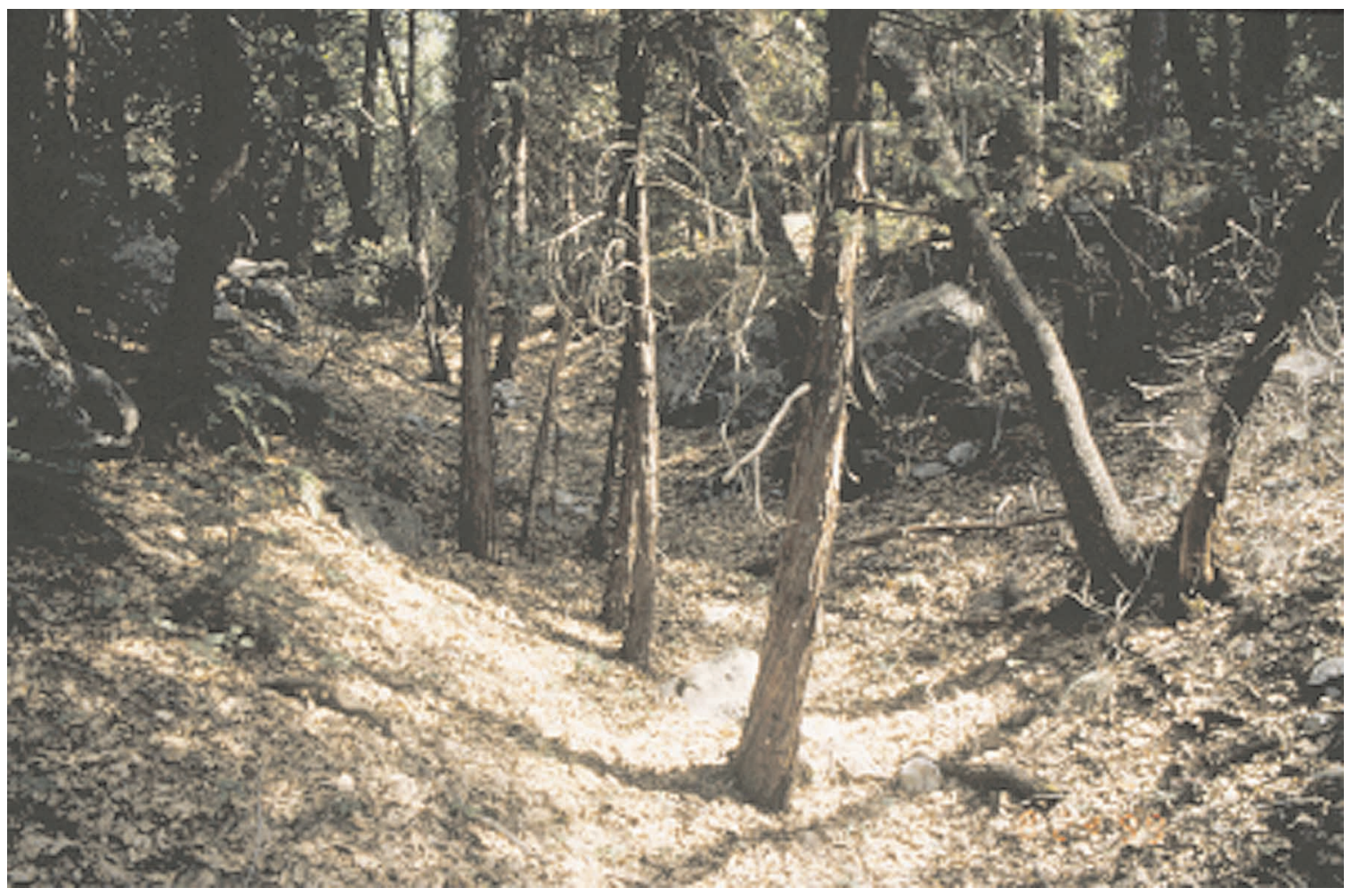

Figure 8. Abandoned debris flow channel on the medial part of Rattlesnake Canyon debris flow fan. This channel was abandoned relatively recently based on the age of the cedar trees growing in the channel. 


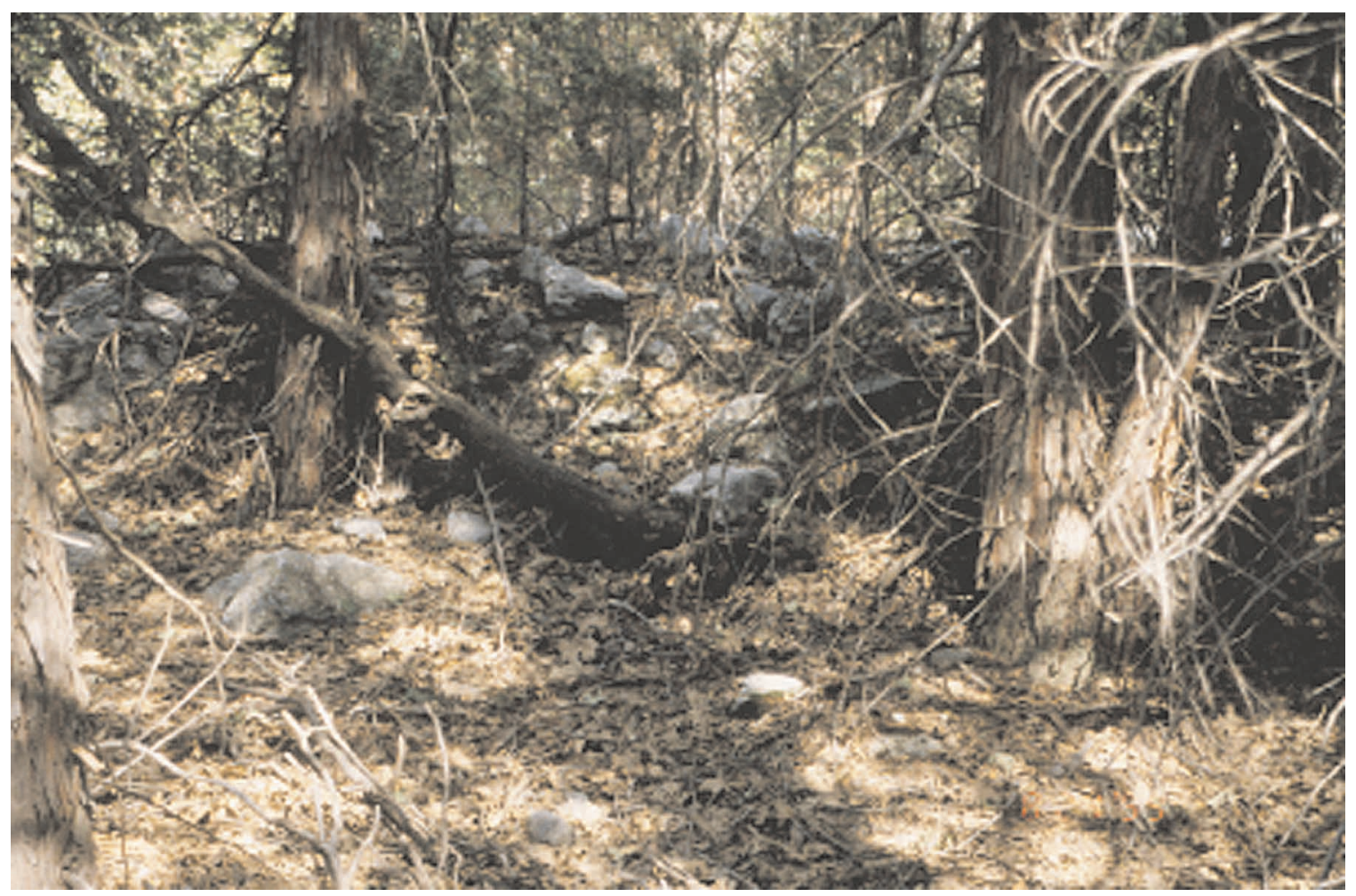

Figure 9. Steep front of broad debris flow snout on the medial part of Rattlesnake debris flow fan. Cedar trees at base of the flow predate the flow and the smaller cedar trees on the upper surface of the flow postdate the flow. 


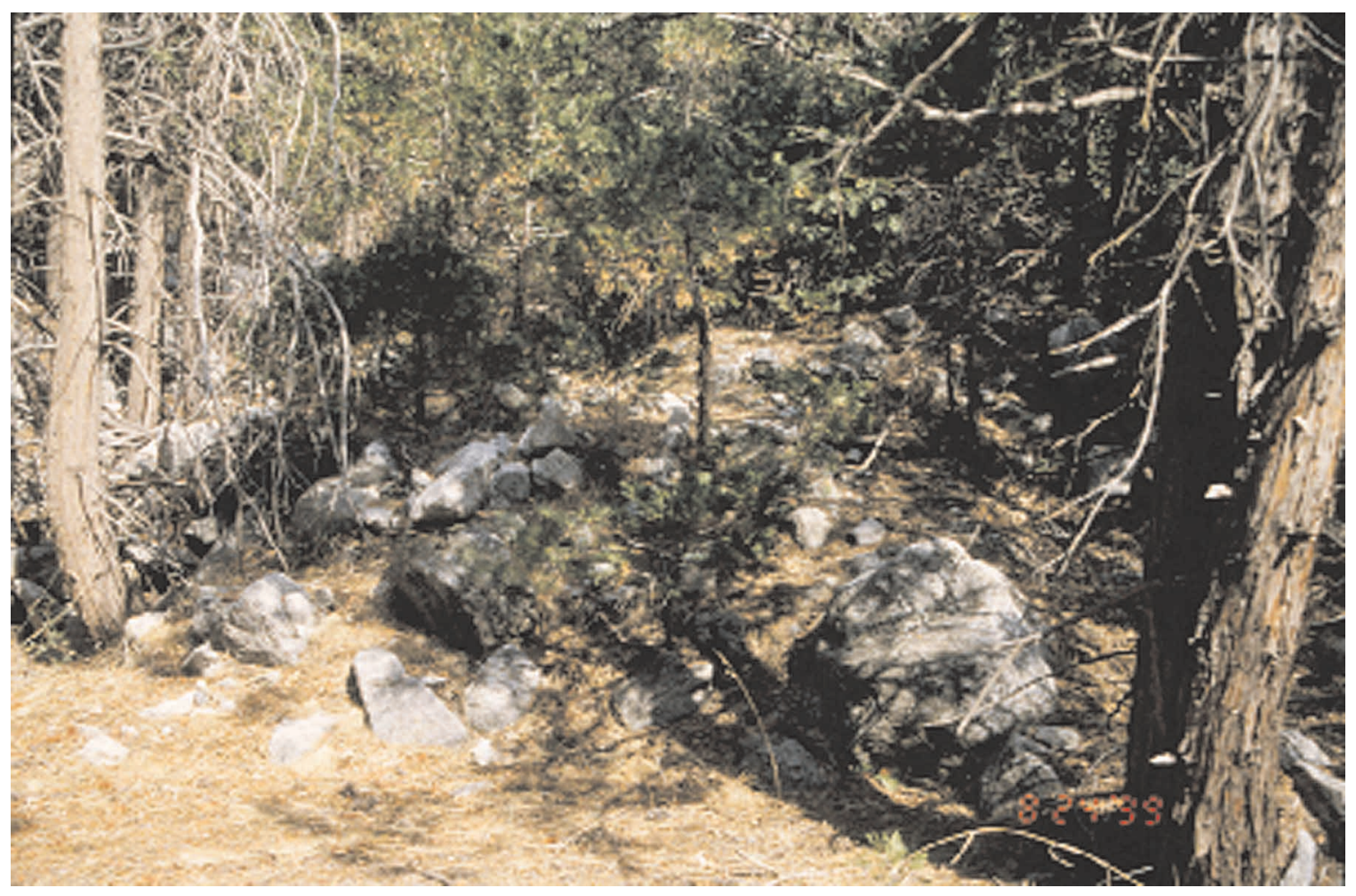

Figure 10. Snout of narrow debris flow on medial part of Rattlesnake debris flow fan. Cedar trees at base of the flow predate the flow and the smaller cedar trees on the upper surface of the flow postdate the flow. 


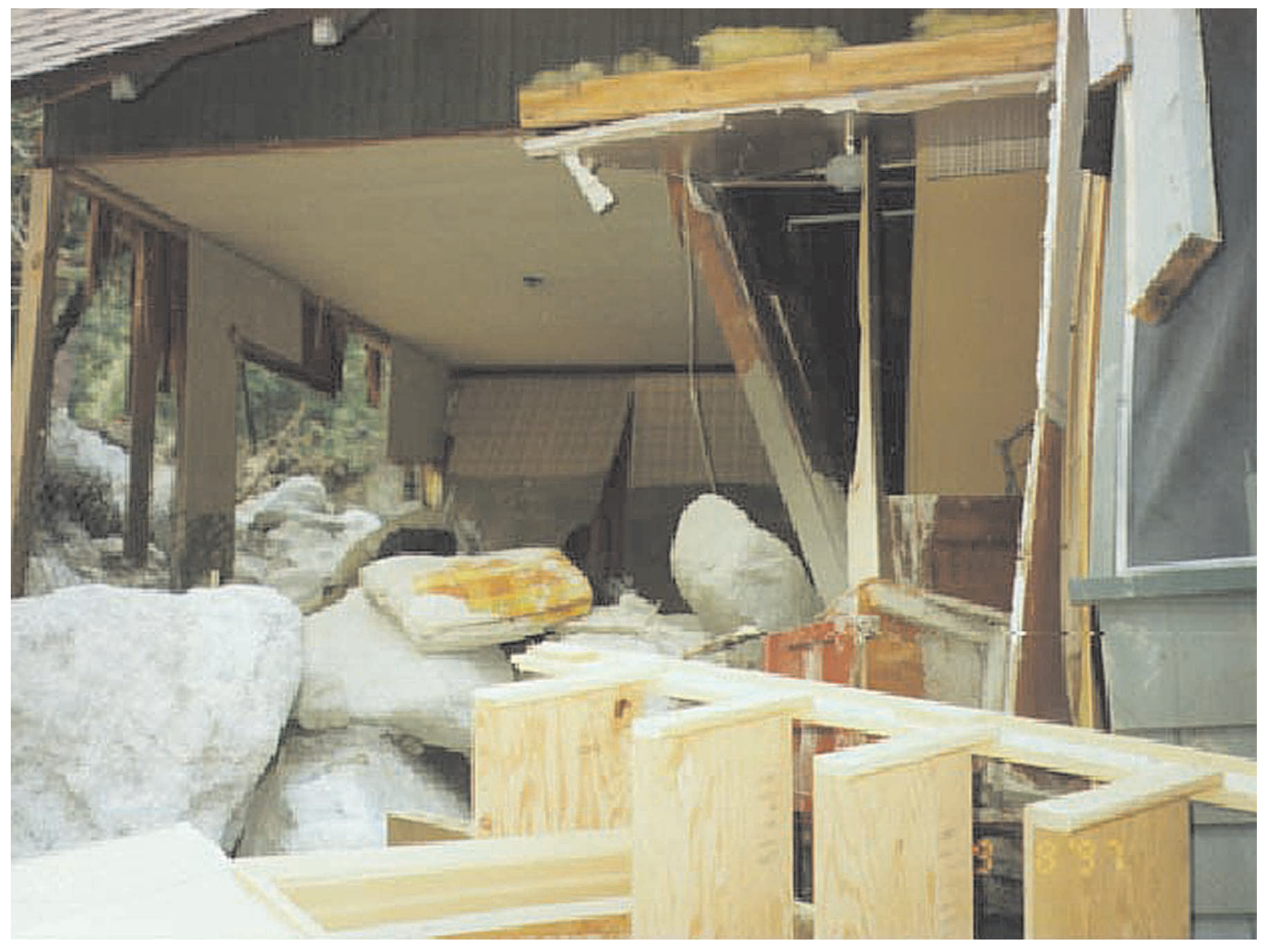

Figure 11. House damaged by a relatively fast moving debris flow of 1997. The 'clean' nature of the deposit suggests a relatively high water content to the flow. Photograph by W.E. Reeder. 


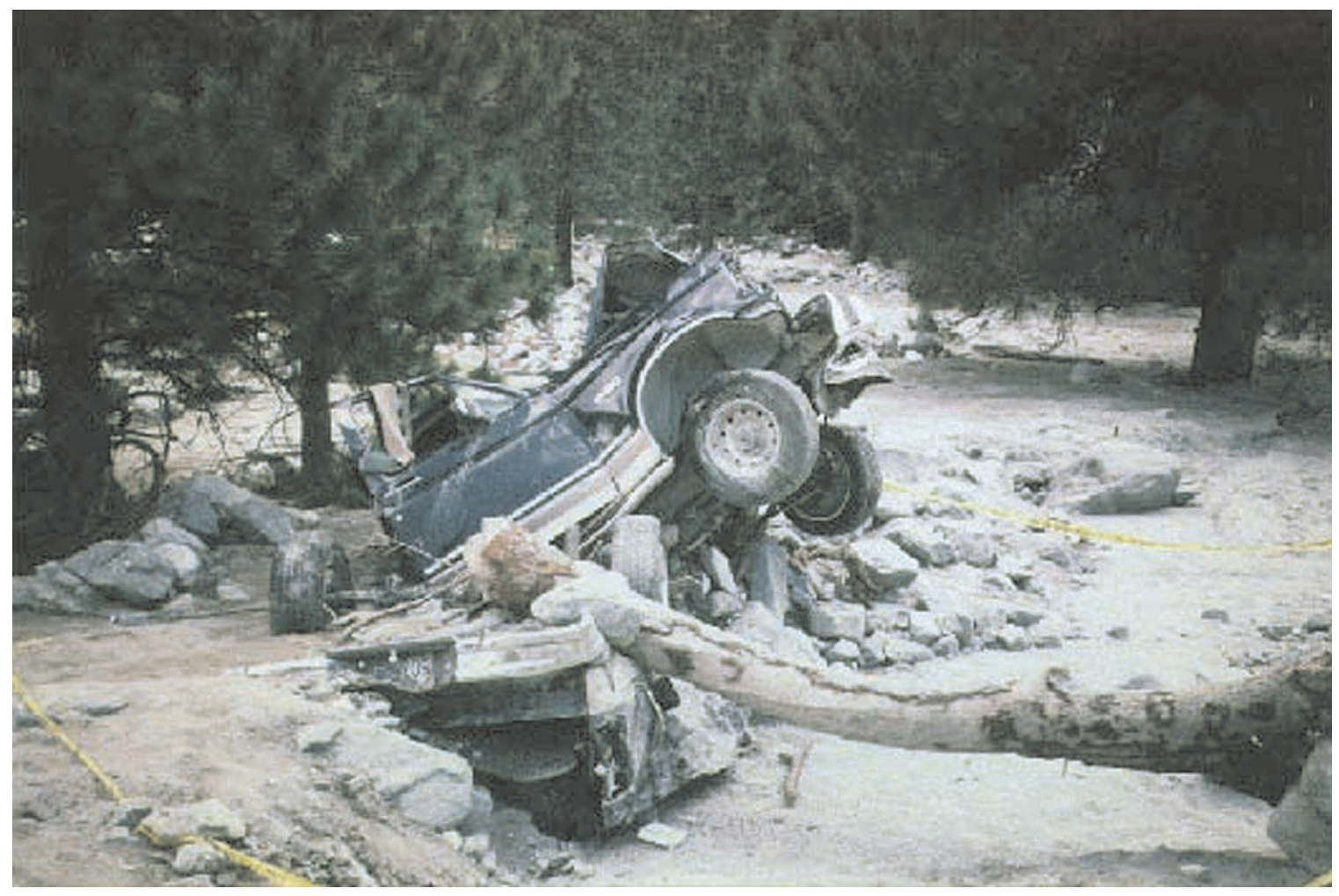

Figure 12. Vehicles destroyed by relatively fast moving debris flows of 1997. The 'clean' nature of the deposit suggests a relatively high water content to the flow. Photograph by W.E. Reeder. 


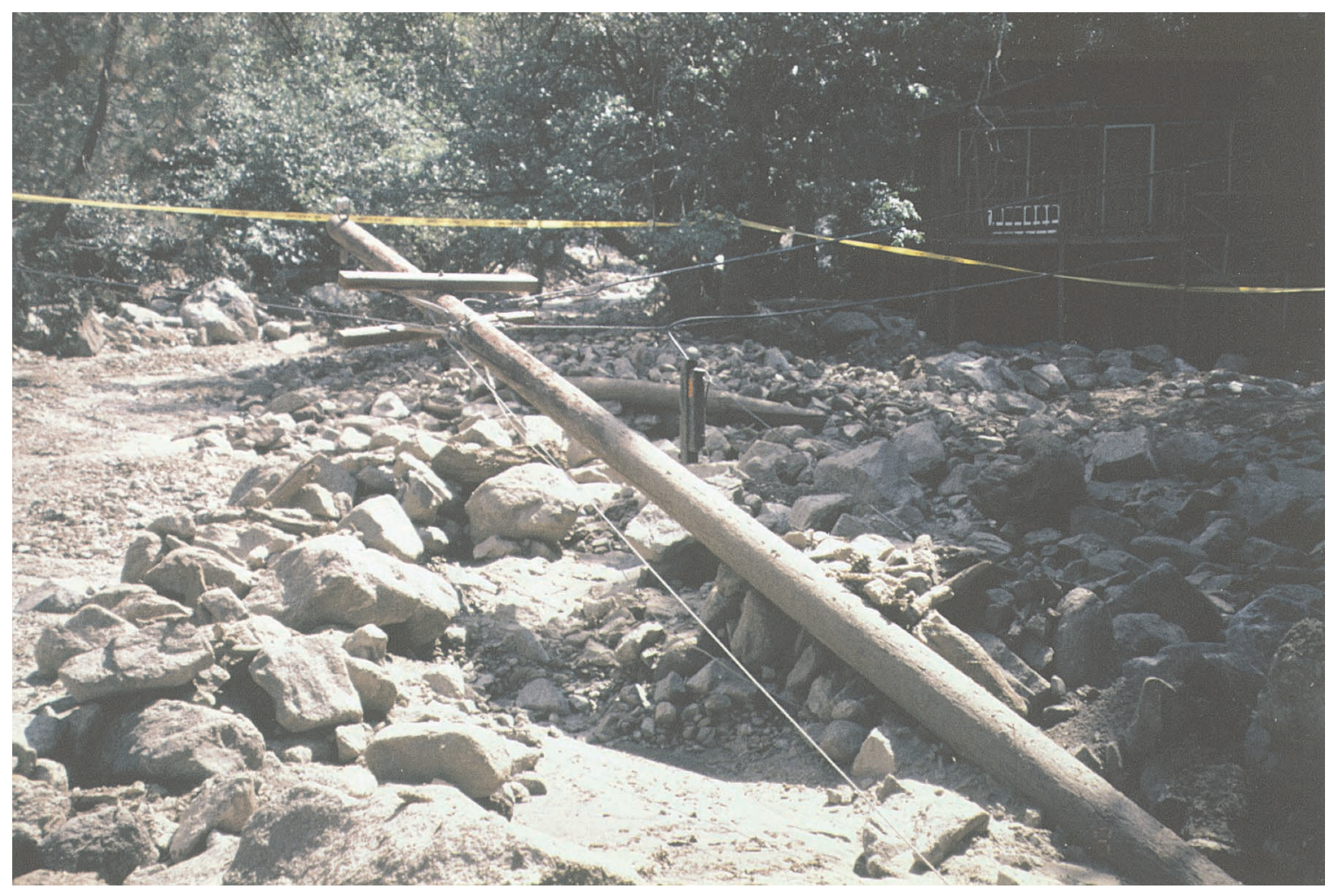

Figure 13. Utility lines downed by the debris flows of 1997. Photograph by W.E. Reeder. 


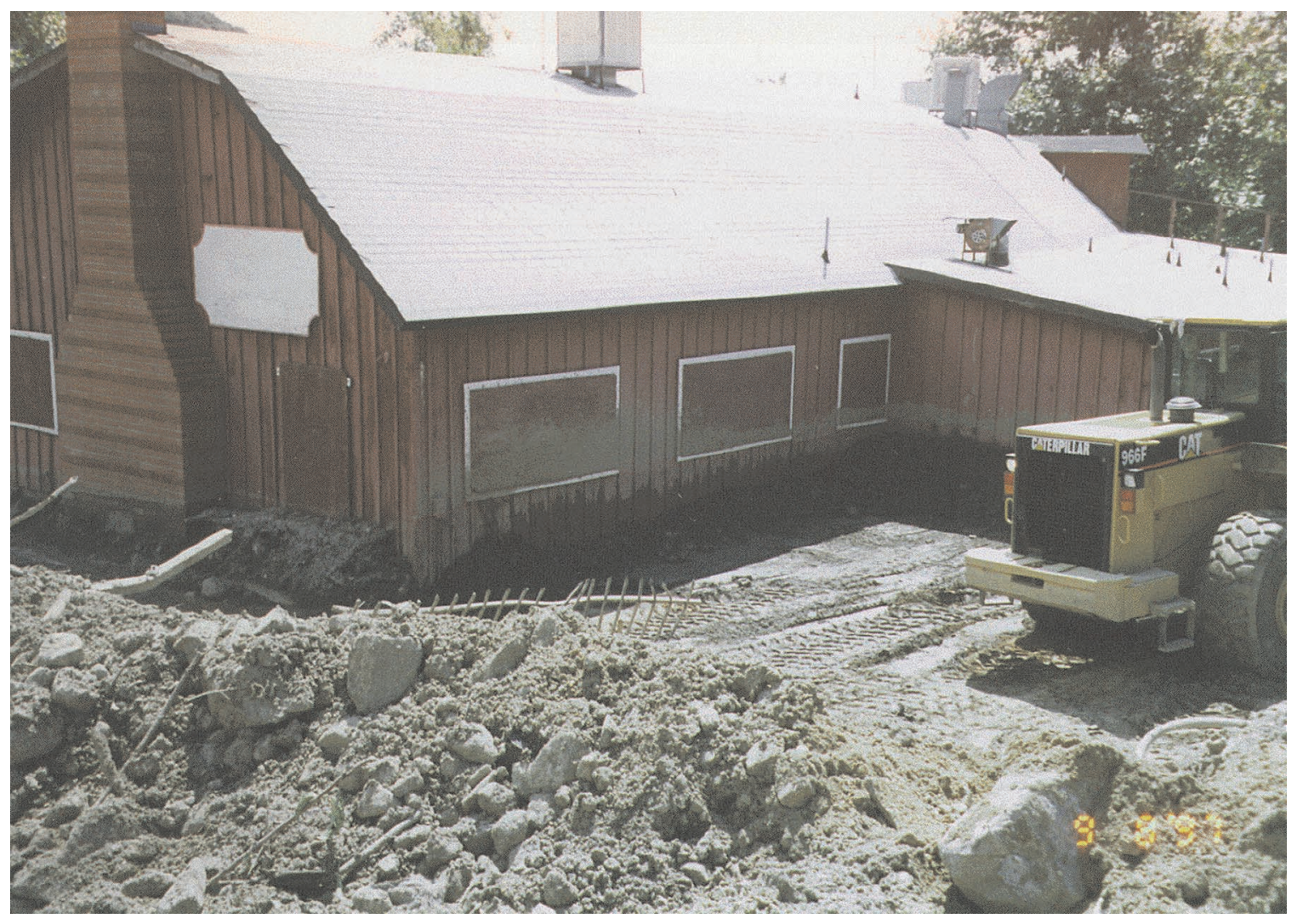

Figure 14. House partly inundated by slow moving debris flow of 1997. Note there appears to be no structural damage to the house produced by the slow moving debris flow. Photograph by W.E. Reeder. 


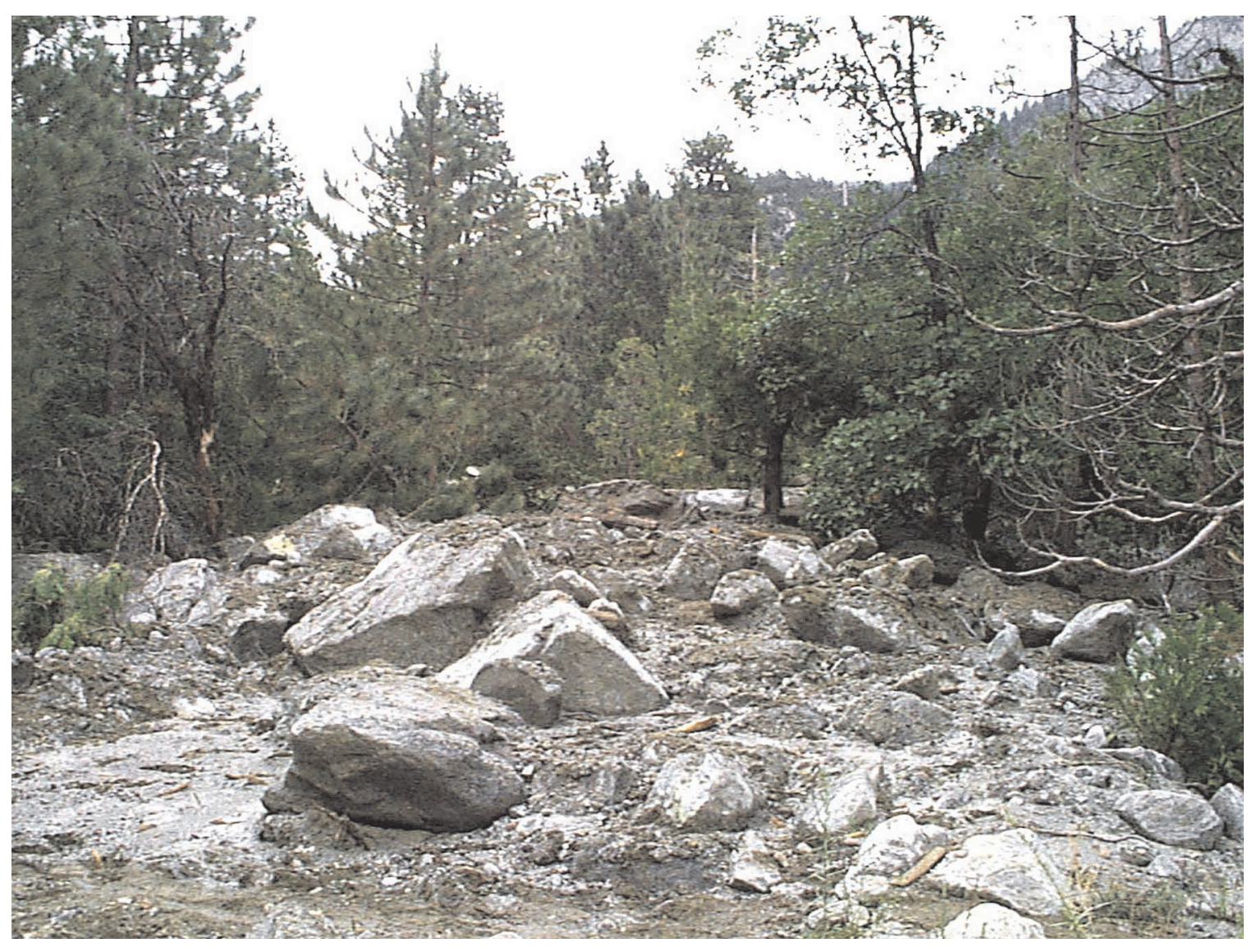

Figure 15. Snout of a slow-moving debris flow of July 11, 1999, Rattlesnake fan. Looking south up the fan. The larger boulders are about five feet in length. Some watery matrix is oozing from the left side of the flow. Photograph taken July 12, 1999. 


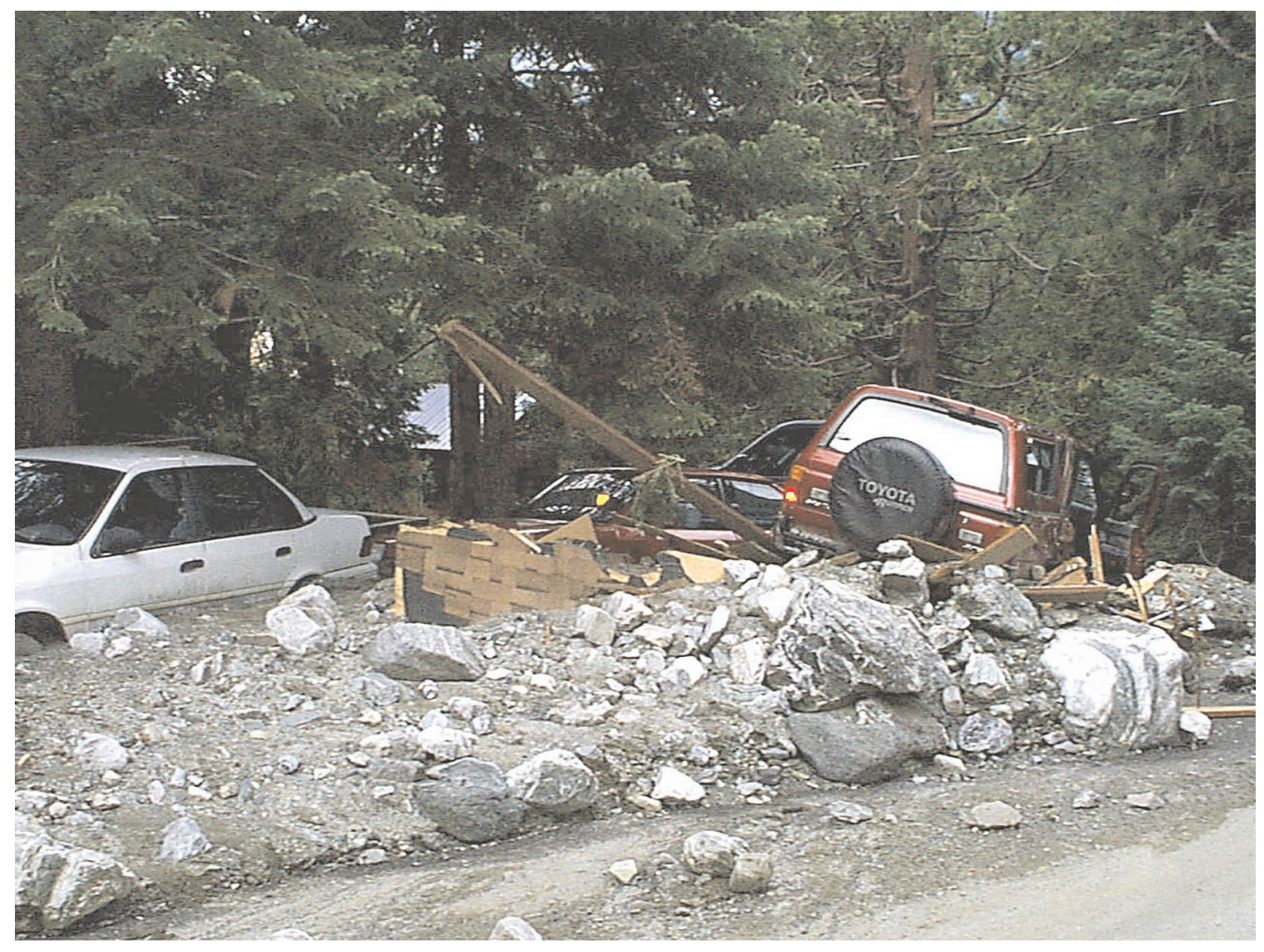

Figure 16. Remnant of the distal part of the 1999, debris avalanche. Note the 'clean' nature of the deposit. The relatively high water content of the avalanche results in the 'clean' aspect to the deposit. Compare this deposit with the muddy deposits of the slow moving debris flow in Figure 15). 


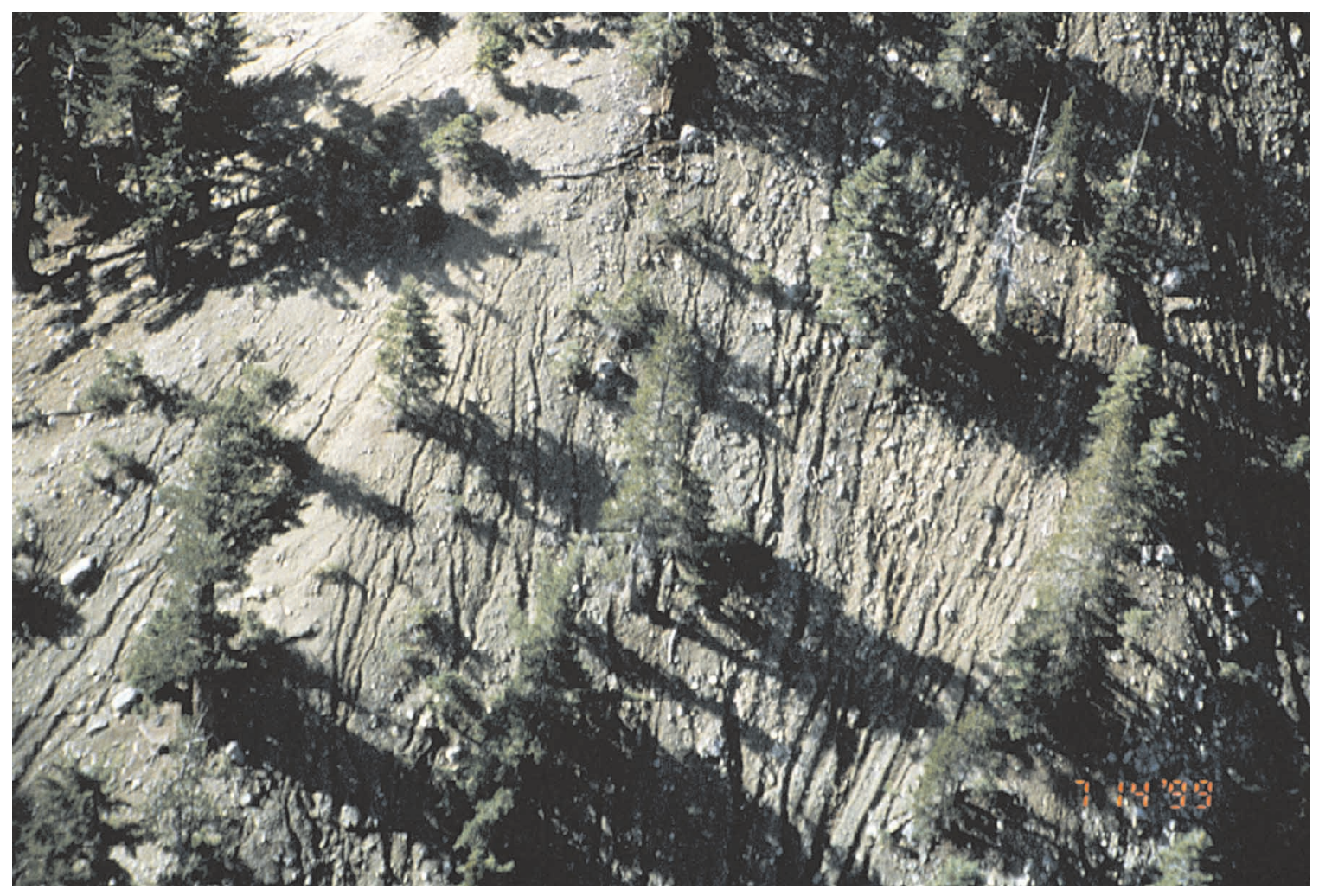

Figure 17. Rills on the upper slopes of Yucaipa Ridge. Intense rainfall of July 11 and 13, 1999 produced these rills. The rills are about one foot in width. Photograph taken July 15, 1999. 


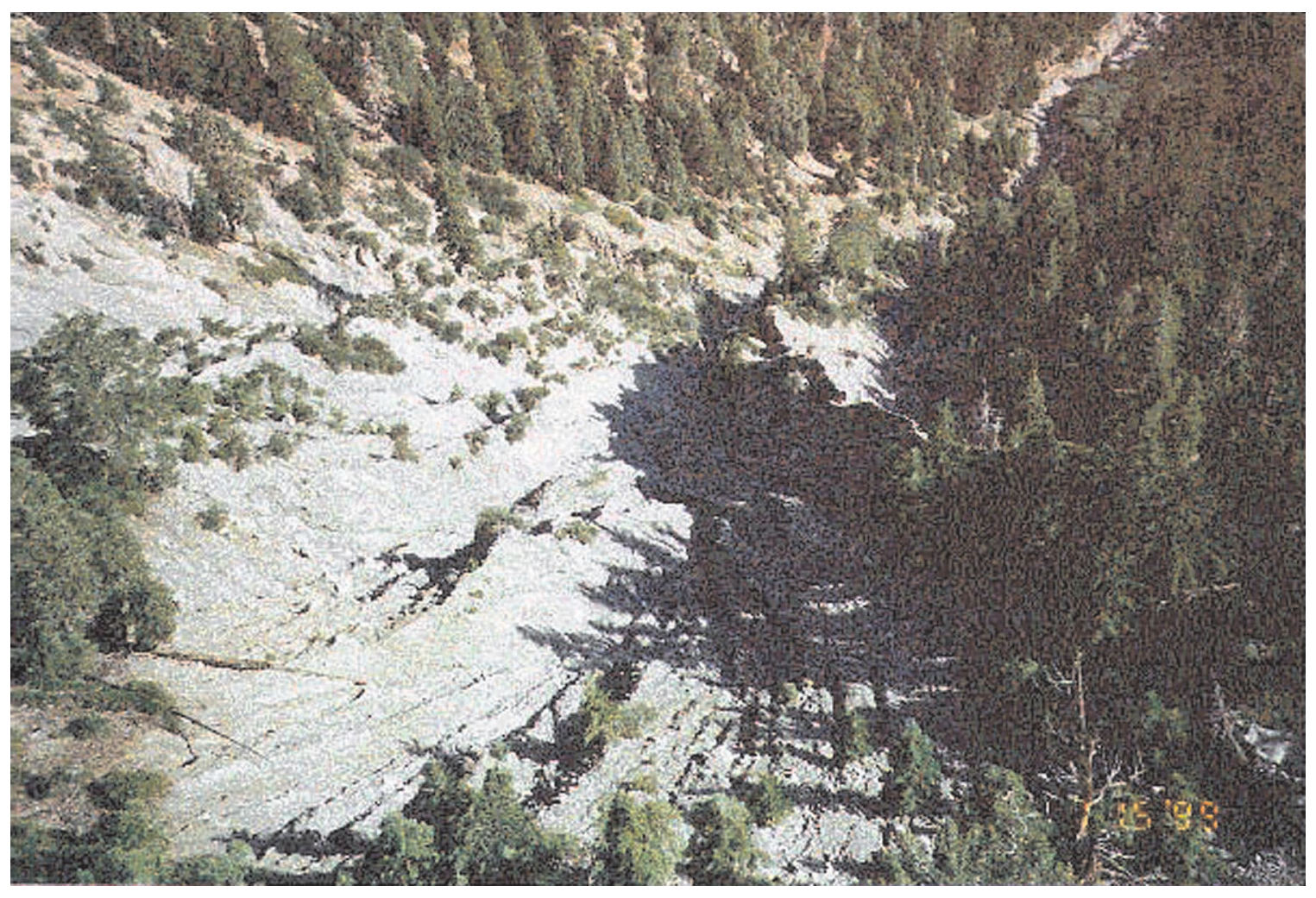

Figure 18. Rills at the head of Snow Creek funneling down slope into a single channel. Note the relatively small grain size to the hillside material and the extensive erosion of this material by the rilling. This photograph is looking down slope from the site of Figure 17. Photograph taken July 15, 1999, W.E. Reeder. 


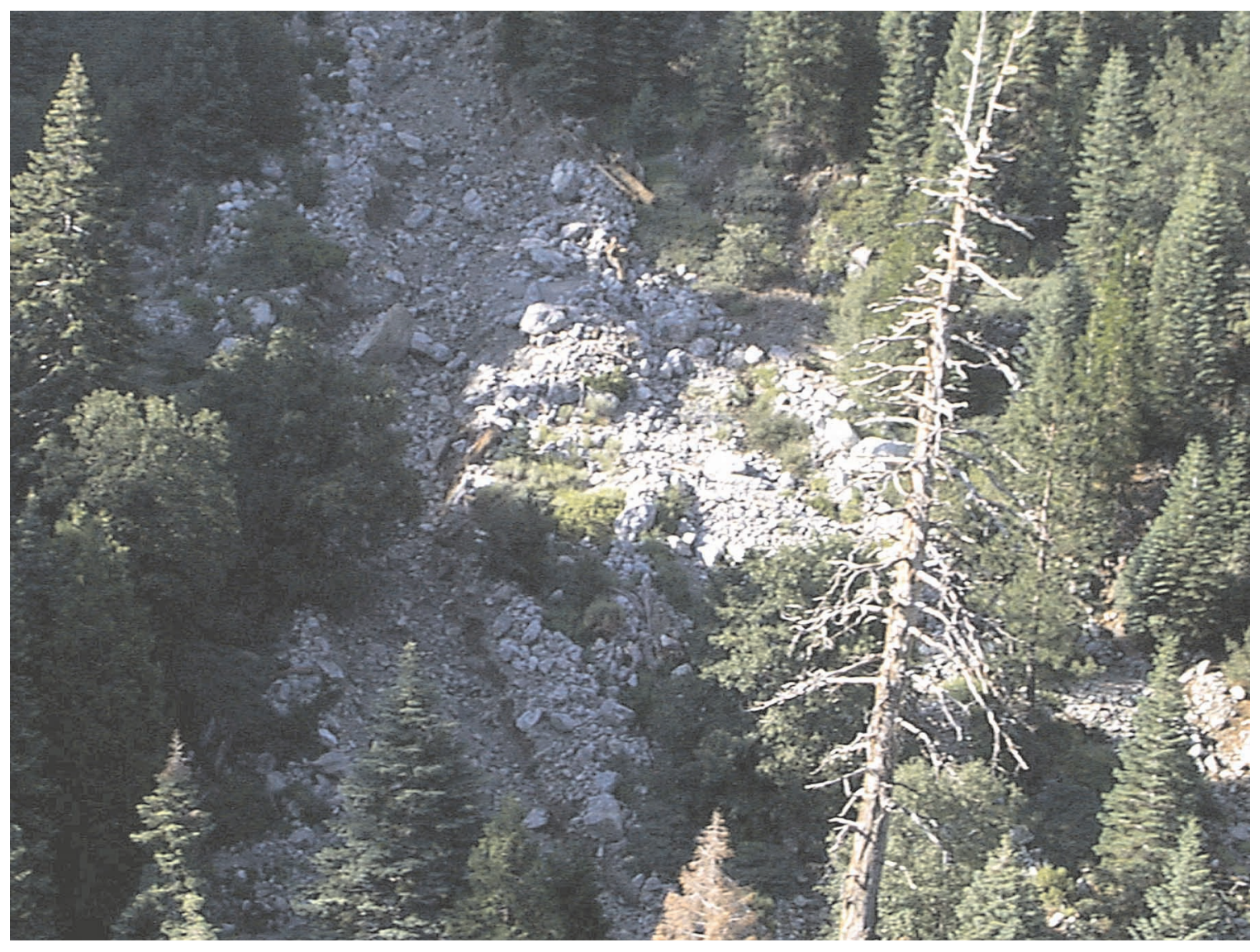

Figure 19. Debris flow deposits in the upper part of Snow Creek at the proximal part of the debris flow fan. There is no debris flow channel developed on the upper proximal part of the fan. 


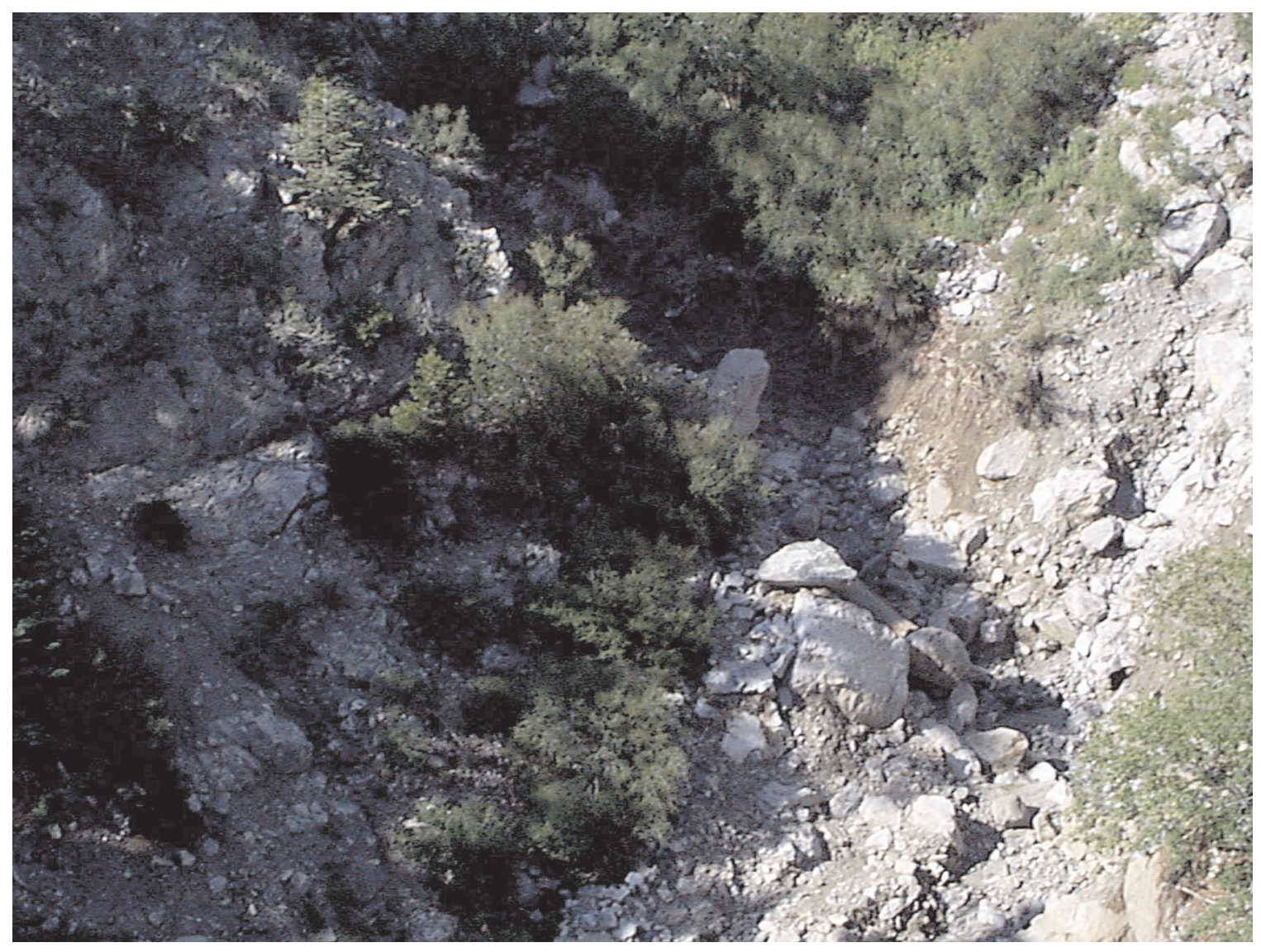

Figure 20. Debris flow deposits on the lower proximal part of Snow Creek debris flow fan. Here, on the right side of the photograph, is a new channel cut by the debris avalanche and debris flows of July 11 and 13 . In this reach the relatively fine-grained rilled debris incorporated boulders at the channel was cut. Compare this channel with the well-developed channel in Figure 26. Photograph taken July 15, 1999. 


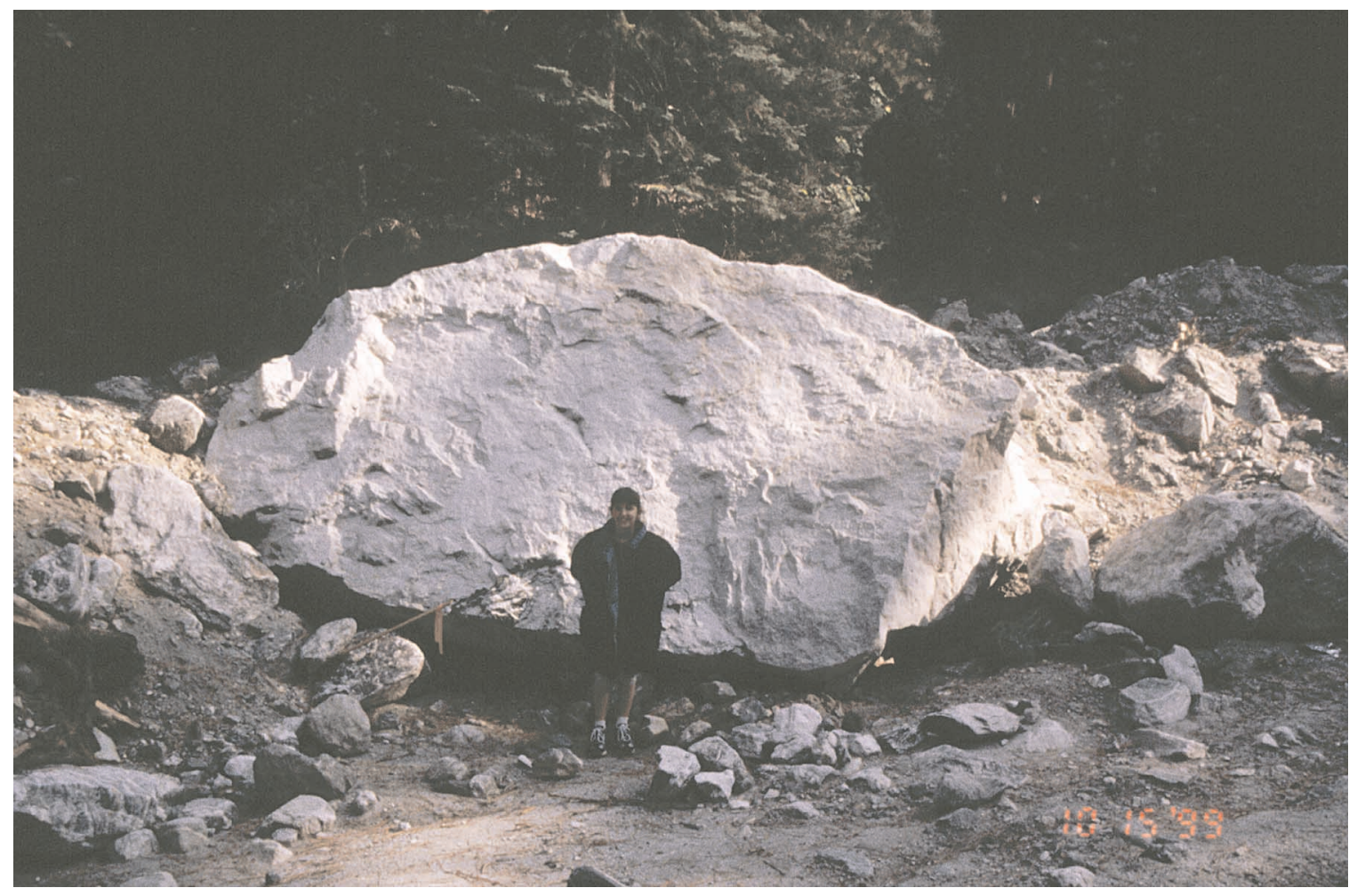

Figure 21. Boulder transported by the July 11, 1999, debris avalanche. The boulder is 16 feet in length and weighs approximately 70 tons. The rocky debris to the sides of the boulder is the result of deepening Snow Creek channel after the channel was partly filled by the debris flows of July 13, 1999. 


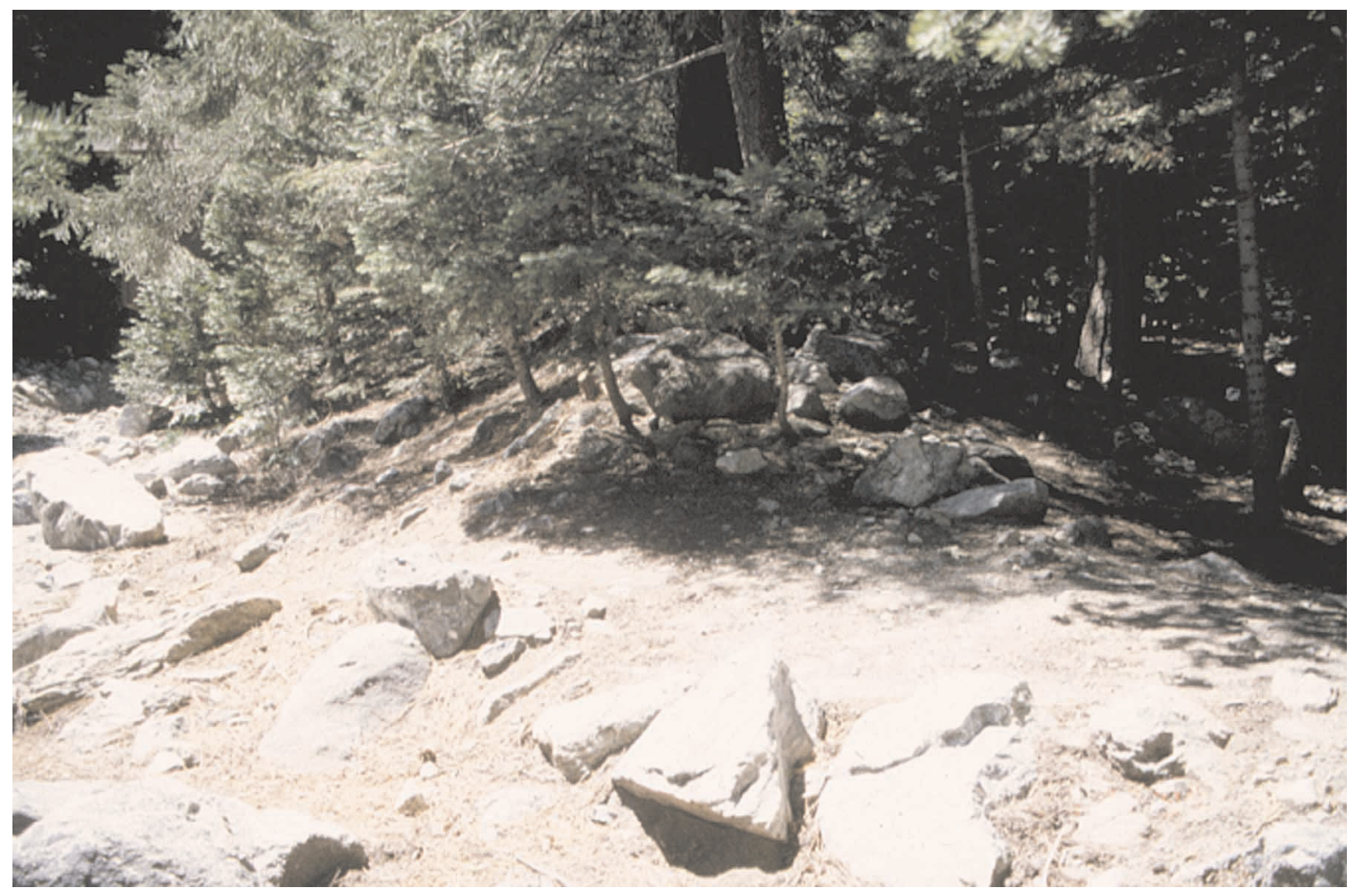

Figure 22. Snow Creek debris flow levee. Debris flow channel to the left of the photograph. The south side of the debris avalanche of July 11, 1999, crossed the levee where the shadows and small trees start. In the foreground the avalanche removed vegetation and surface material. 


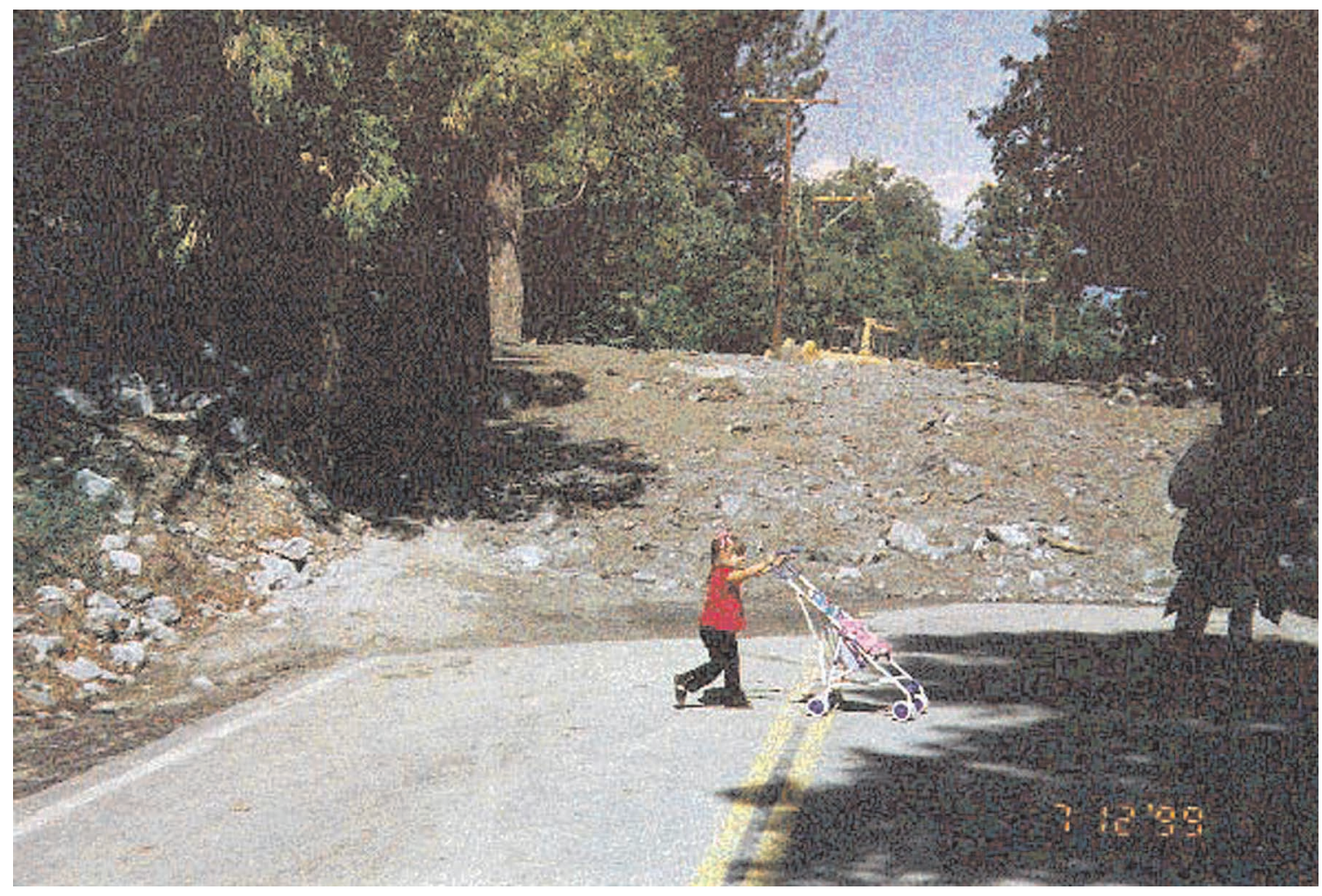

Figure 23. Excavation through the July $11^{\text {th }}$ Rattlesnake Creek debris flows, Valley of the Falls Road. Larger boulders are five-seven feet in length. Photograph taken July 12, 1999, W.E. Reeder. 


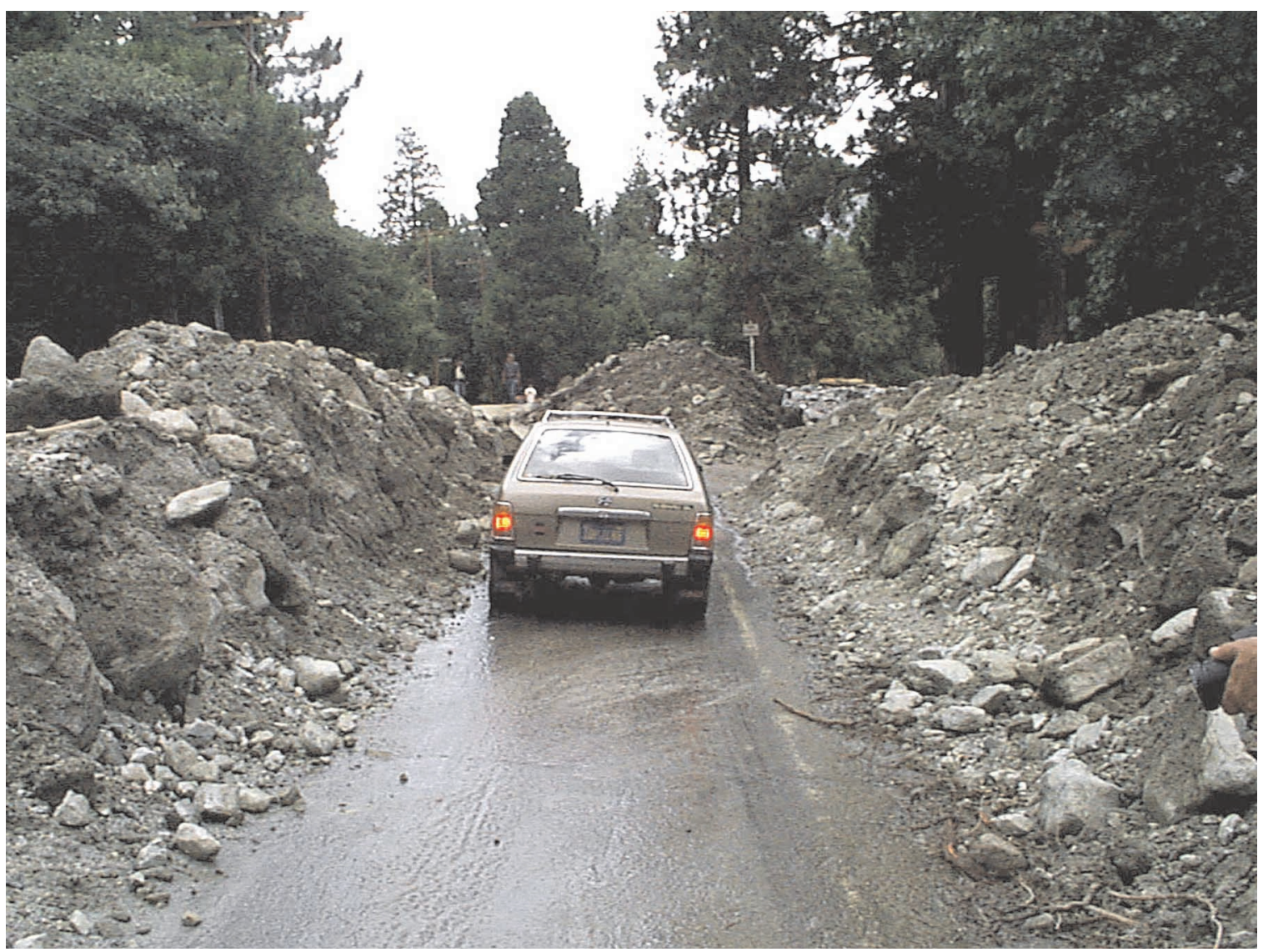

Figure 24. Debris deposited across Valley of the Falls Road by the July 11, 1999, debris flows on Rattlesnake Canyon fan. These deposits cover the road for several hundred feet. Equipment (yellow) is in the process of removing the debris from the road. Photograph taken July 12, 1999. 


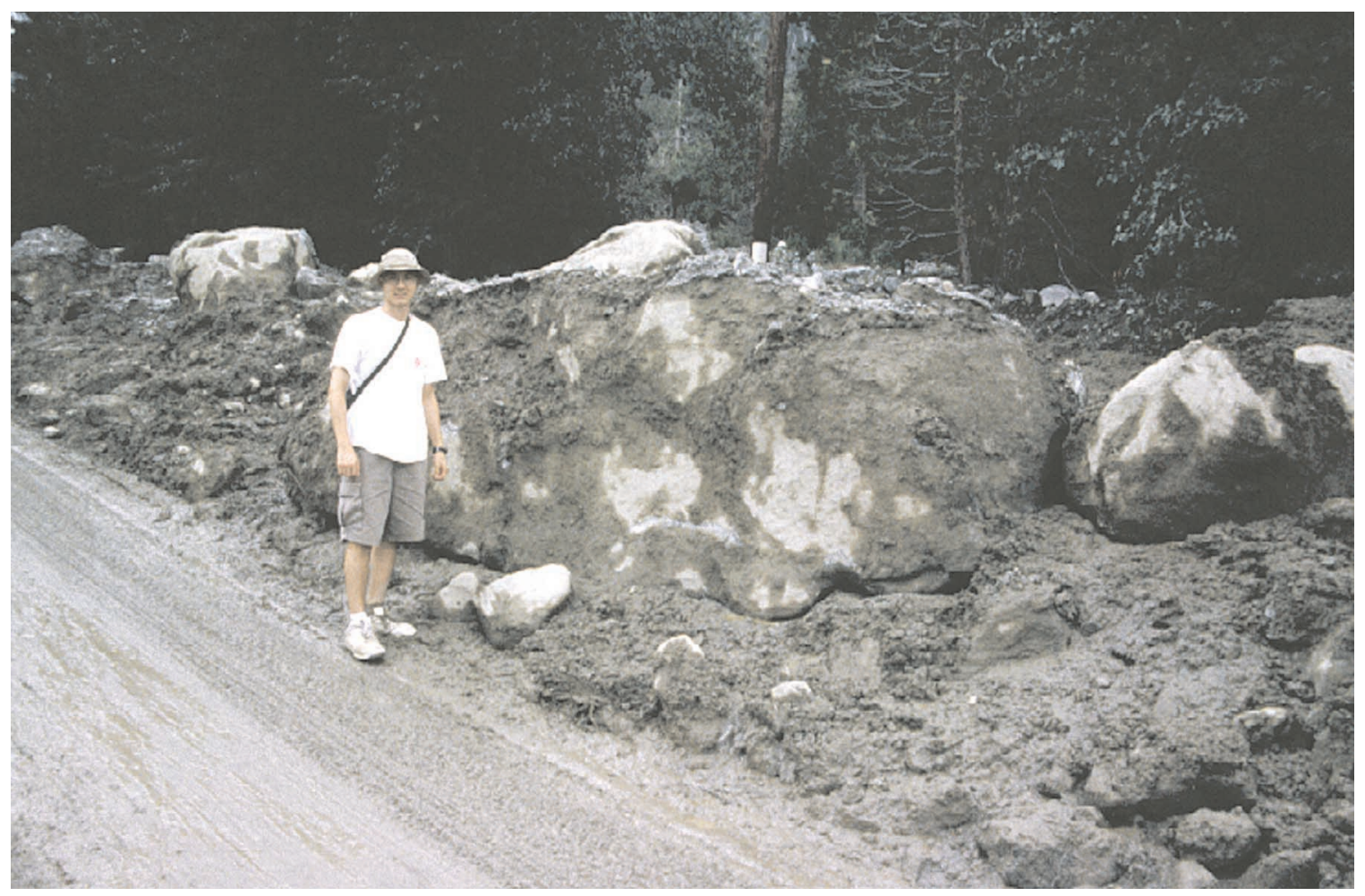

Figure 25. Debris flow deposits, across Valley of the Falls Road. Photograph taken July 12, 1999. 


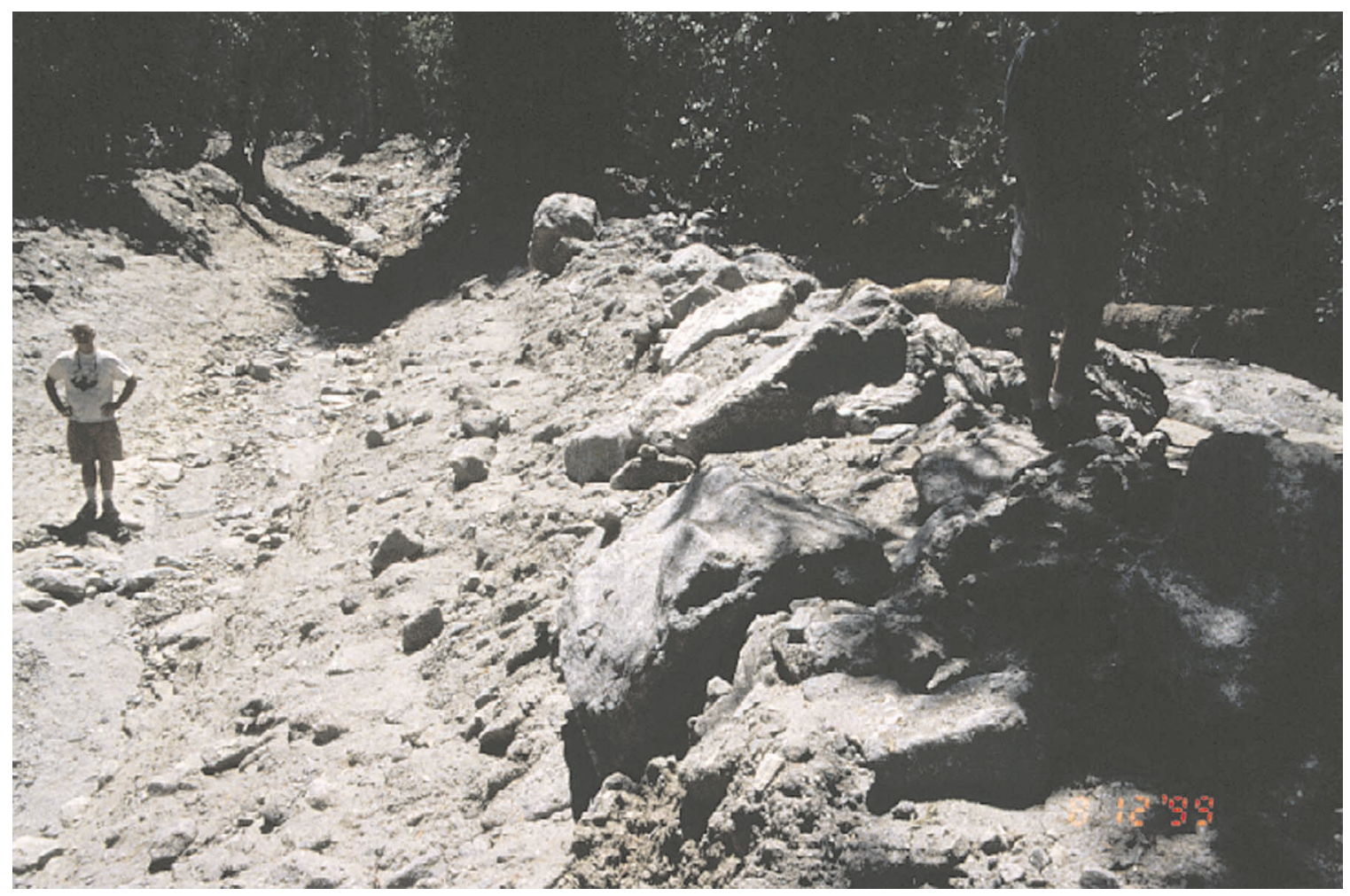

Figure 26. Well-developed debris-flow channel, looking south up the medial part of the Rattlesnake Creek fan. Debris flows of July 11and 13, 1999, added new debris to the crest of the levee on the right side of the channel. 


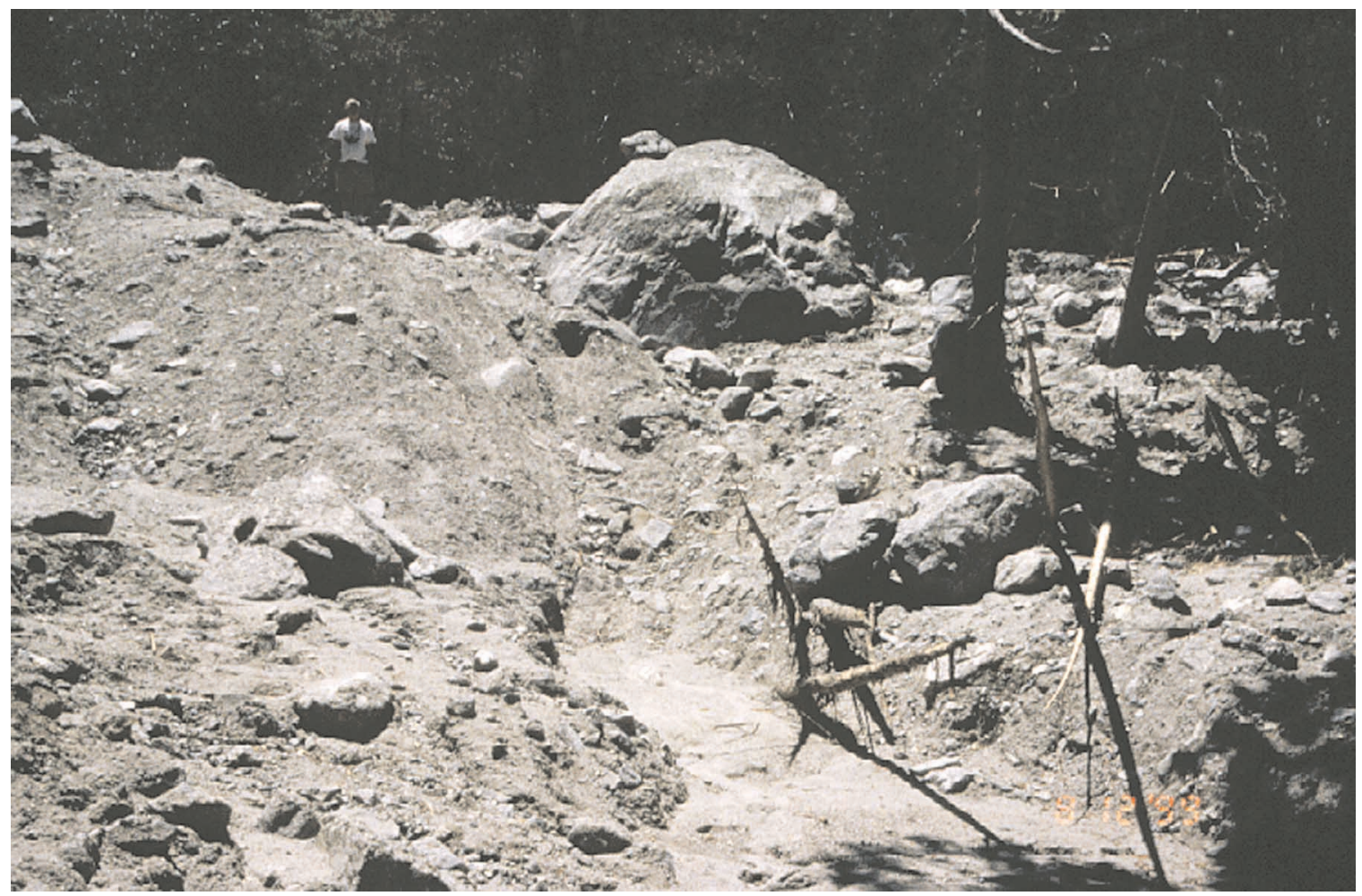

Figure 27. Looking up the blocked part of the Rattlesnake Creek debris flow channel. Person is standing on the top of the snout of the flow that blocked the channel. Figure 26 photograph was taken from the position of the person. Large boulder in center of the photograph is over 10 feet in length. Note the tree trunks in the lower right corner of the photograph that were flattened and debarked by debris flows of July 11, 1999. 


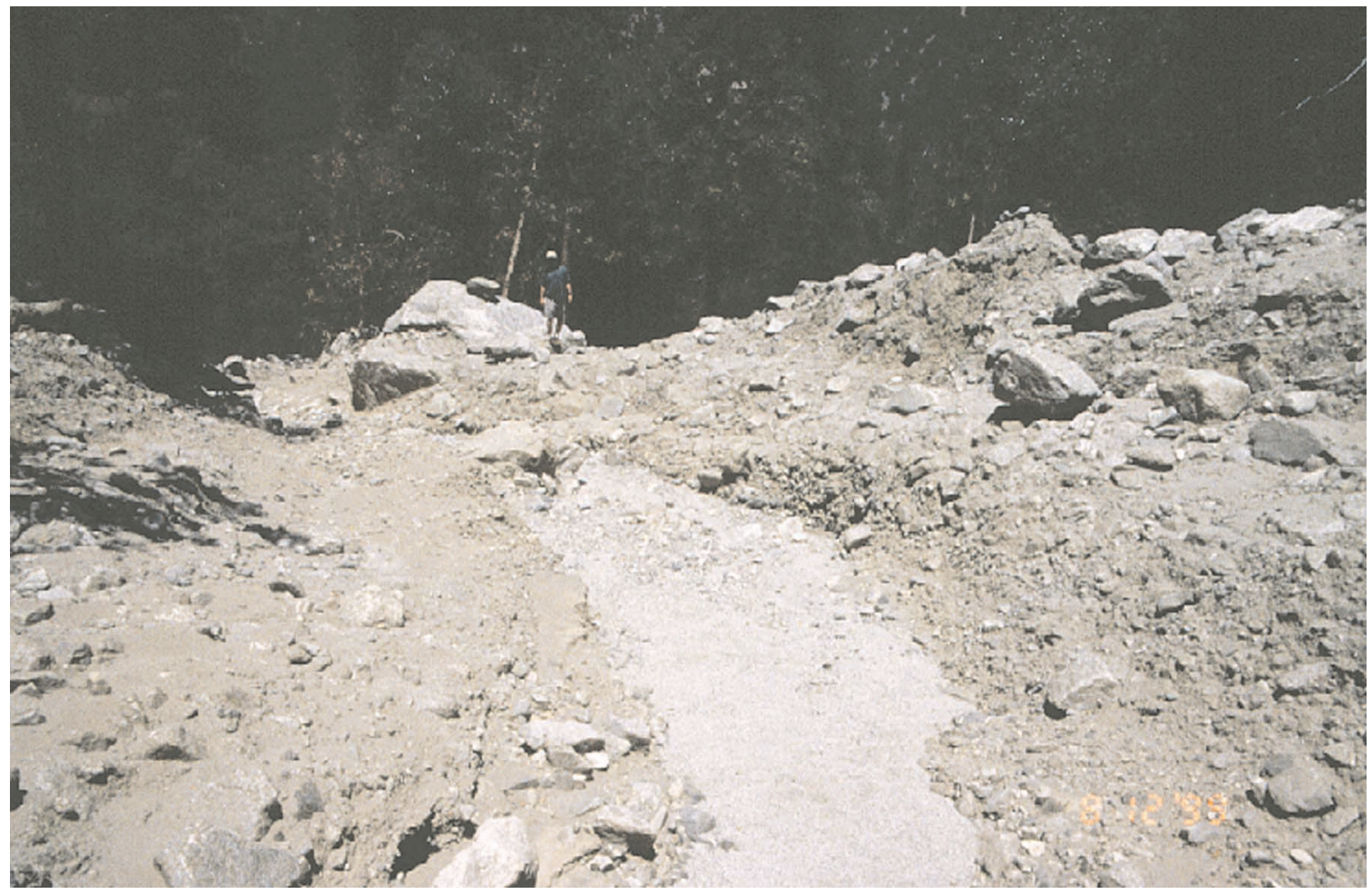

Figure 28. Looking down Rattlesnake Creek channel that was abandoned on July 11 or July 13, 1999, from the position of Figure 27 photograph. Light gray fluvial sand and gravel in channel bottom is the result of water draining from the debris flow that blocked the channel. Large boulder behind the person is about 12 feet in length. 


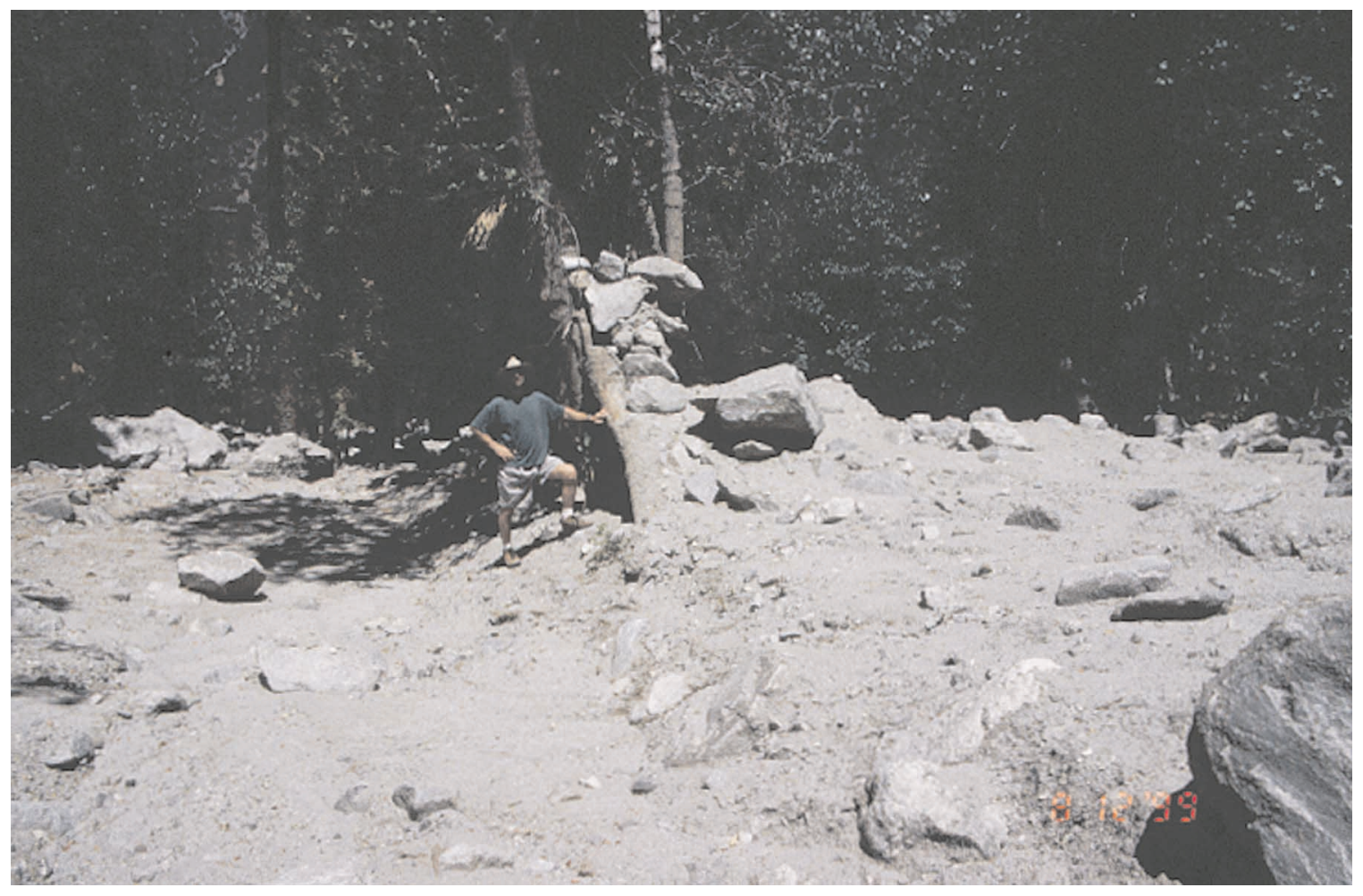

Figure 29. Clasts of the July 11, 1999, debris flows perched in tree, Rattlesnake Creek debris flow channel. The height of these clasts indicates the crest of the debris flows was over nine feet above the channel floor. 


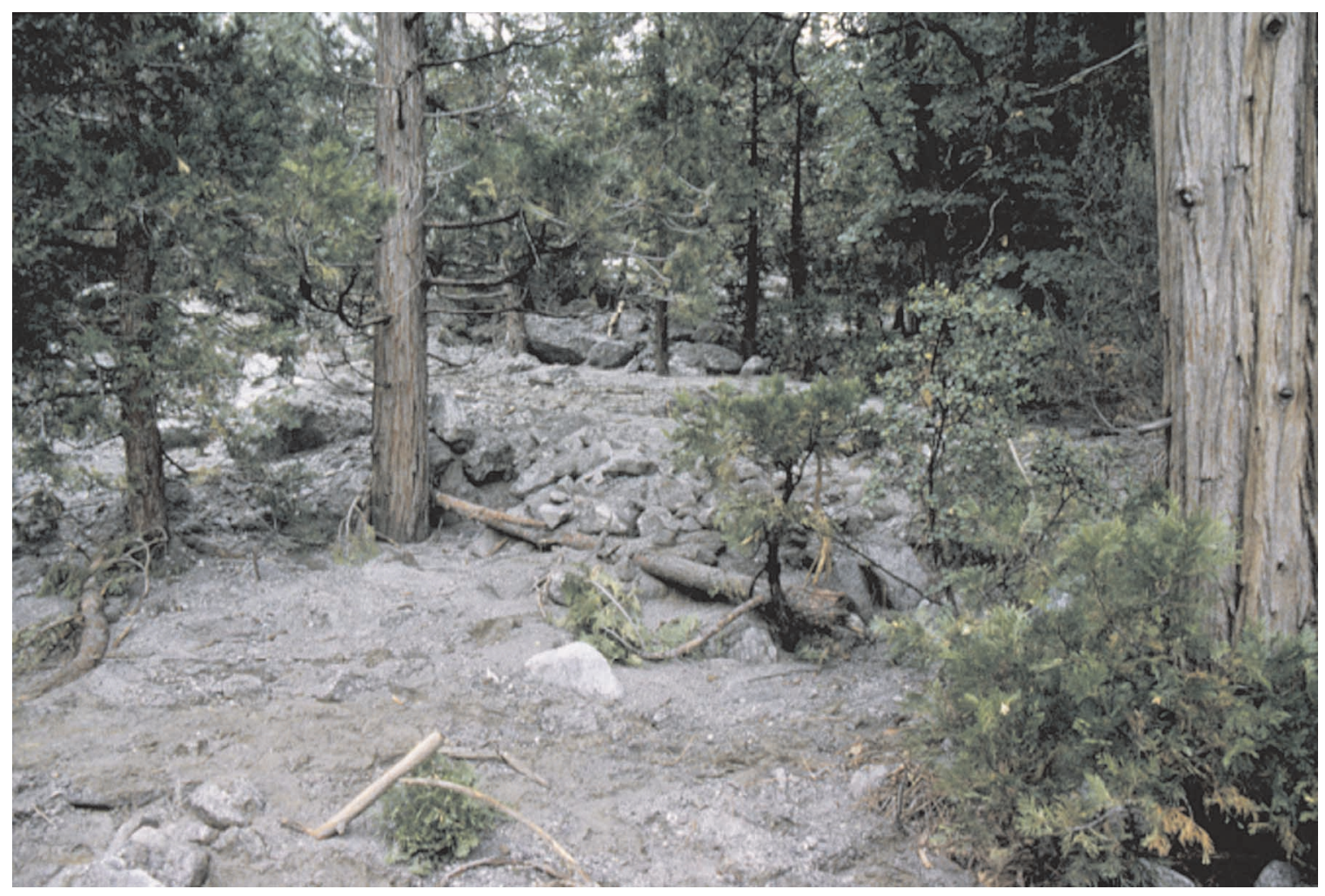

Figure 30. Snout of a stabilized debris flow of July 11, 1999, on the lower part of Rattlesnake fan. This flow stopped on the surface of a larger flow that deposited debris earlier in the day. Photograph taken July 12, 1999. 


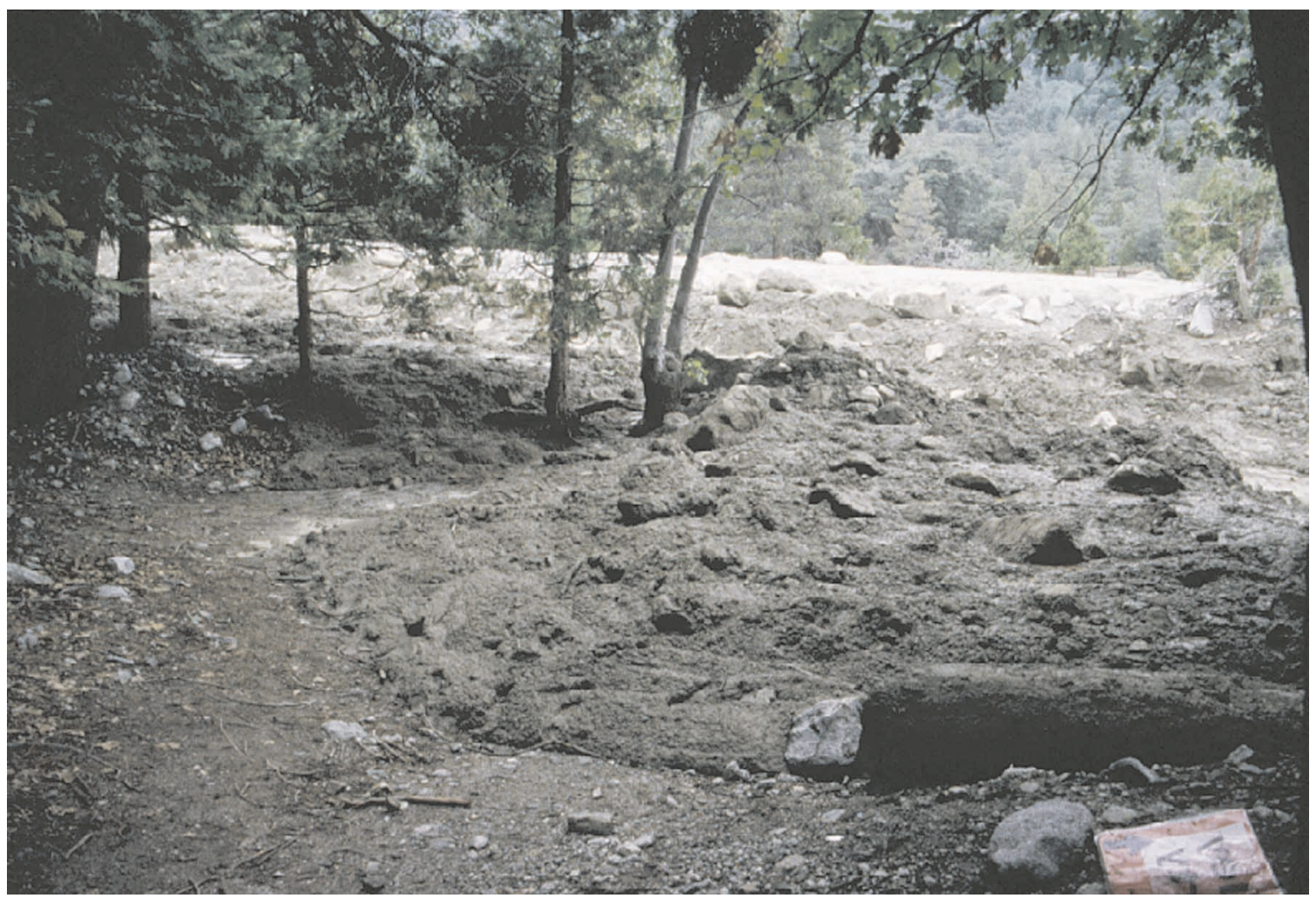

Figure 31. Snout of a stabilized debris flow of July 11, 1999, on the lower part of Rattlesnake fan. The gently sloping snout of this flow indicates the flow was relatively fluid. Note the concrete-like nature of the debris flow matrix. 


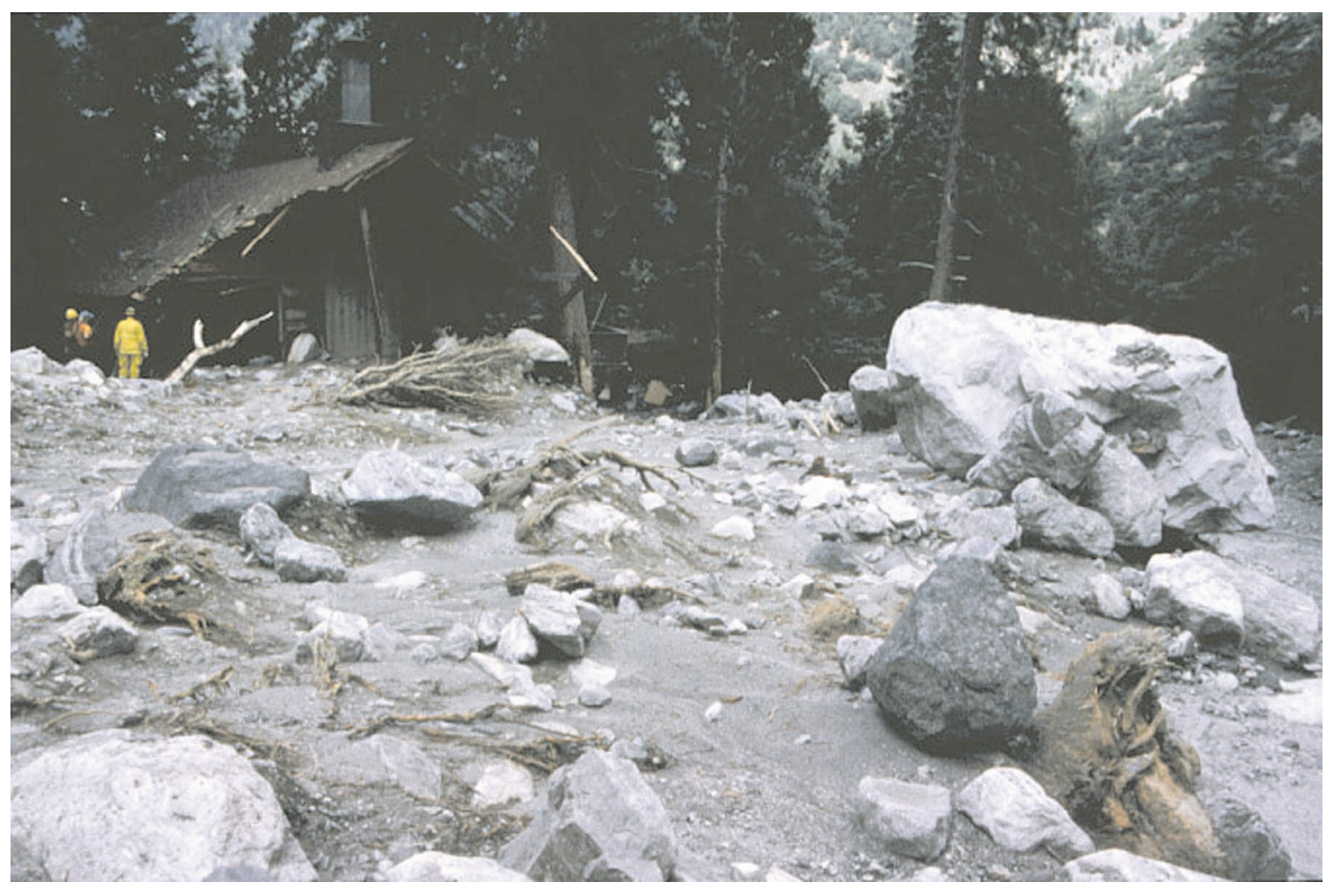

Figure 32. Left side of house was removed by $1^{\text {st }}$ and/or $2^{\text {nd }}$ debris avalanche waves and the right side by the $2^{\text {nd }}$ and/or $3^{\text {rd }}$ avalanche waves, July 11, 1999. Note the 'swept' appearance in foreground produced by avalanche degradation where it removed both rocks and vegetation. Large boulder on right side of the photograph is shown in Figure 21. Photograph taken July 12, 1999. 


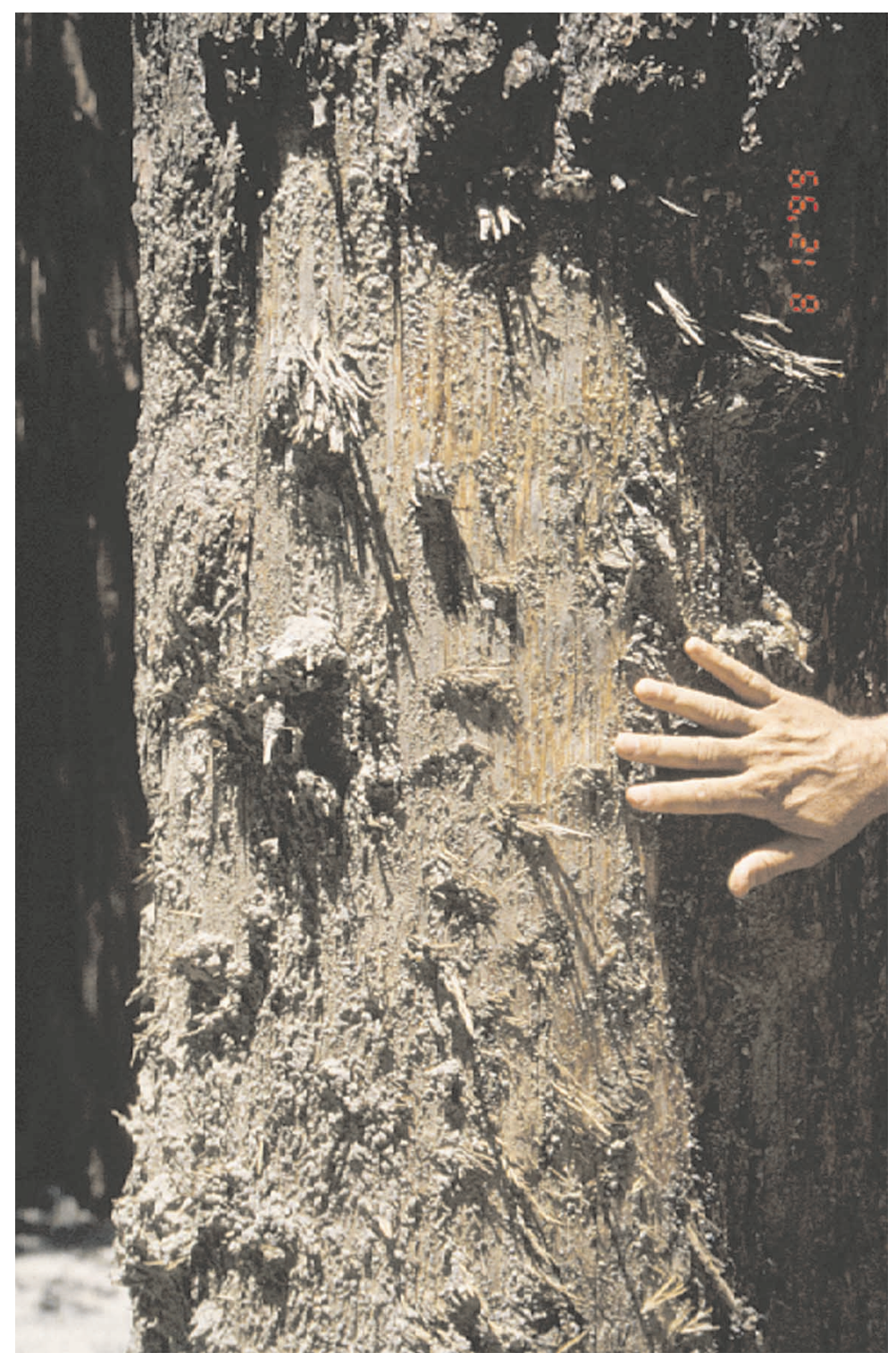

Figure 33. Tree debarked by debris flows, Rattlesnake Creek. Scar above hand was produced by 1997 debris flows; scar below the hand was produced by a combination of both the 1997, and 1999, debris flows. 


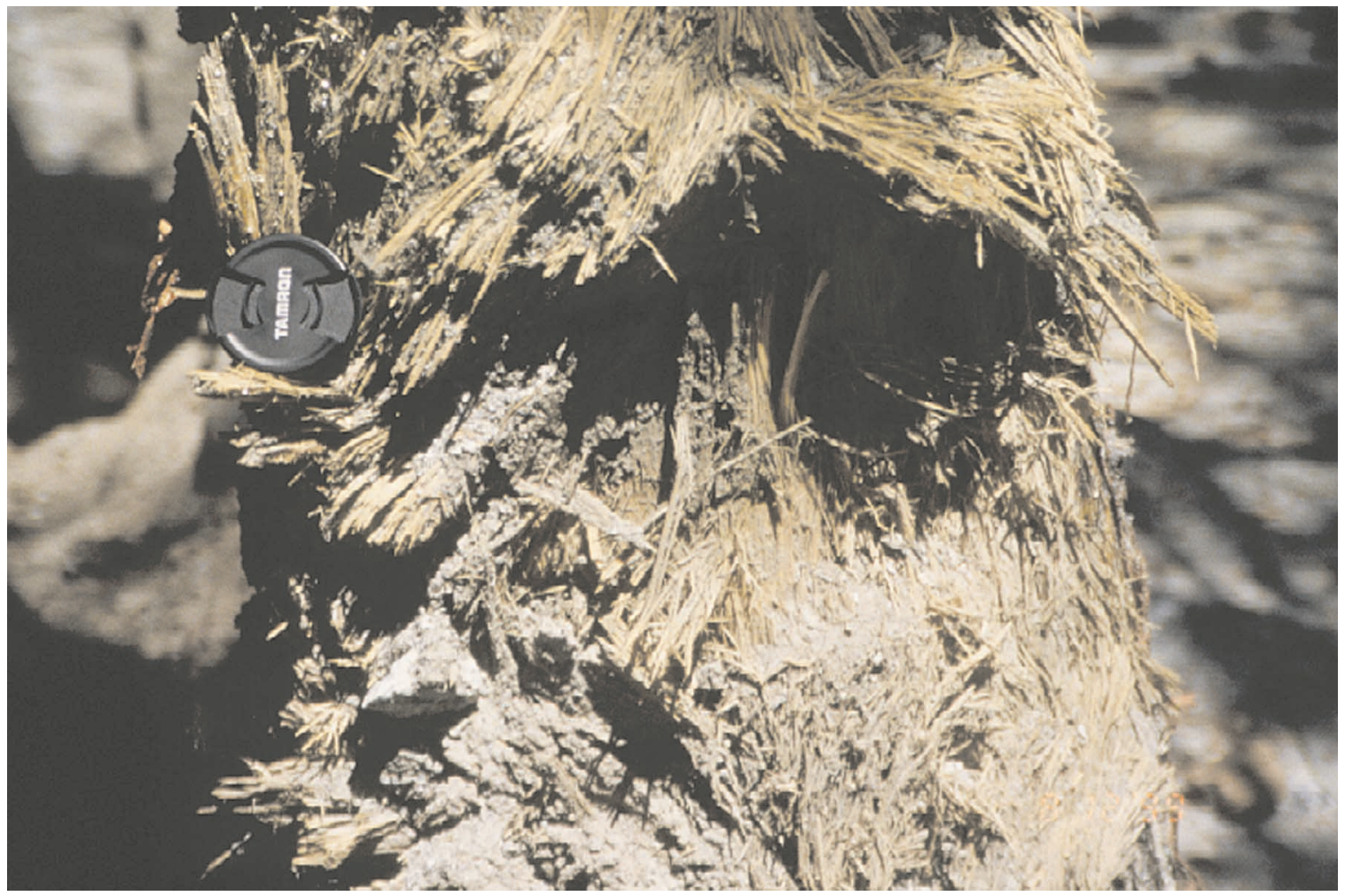

Figure 34. Upslope side of tree fragmented by the July 11, 1999, avalanche. Note the rock embedded in the fragmented wood below the lens cap. 


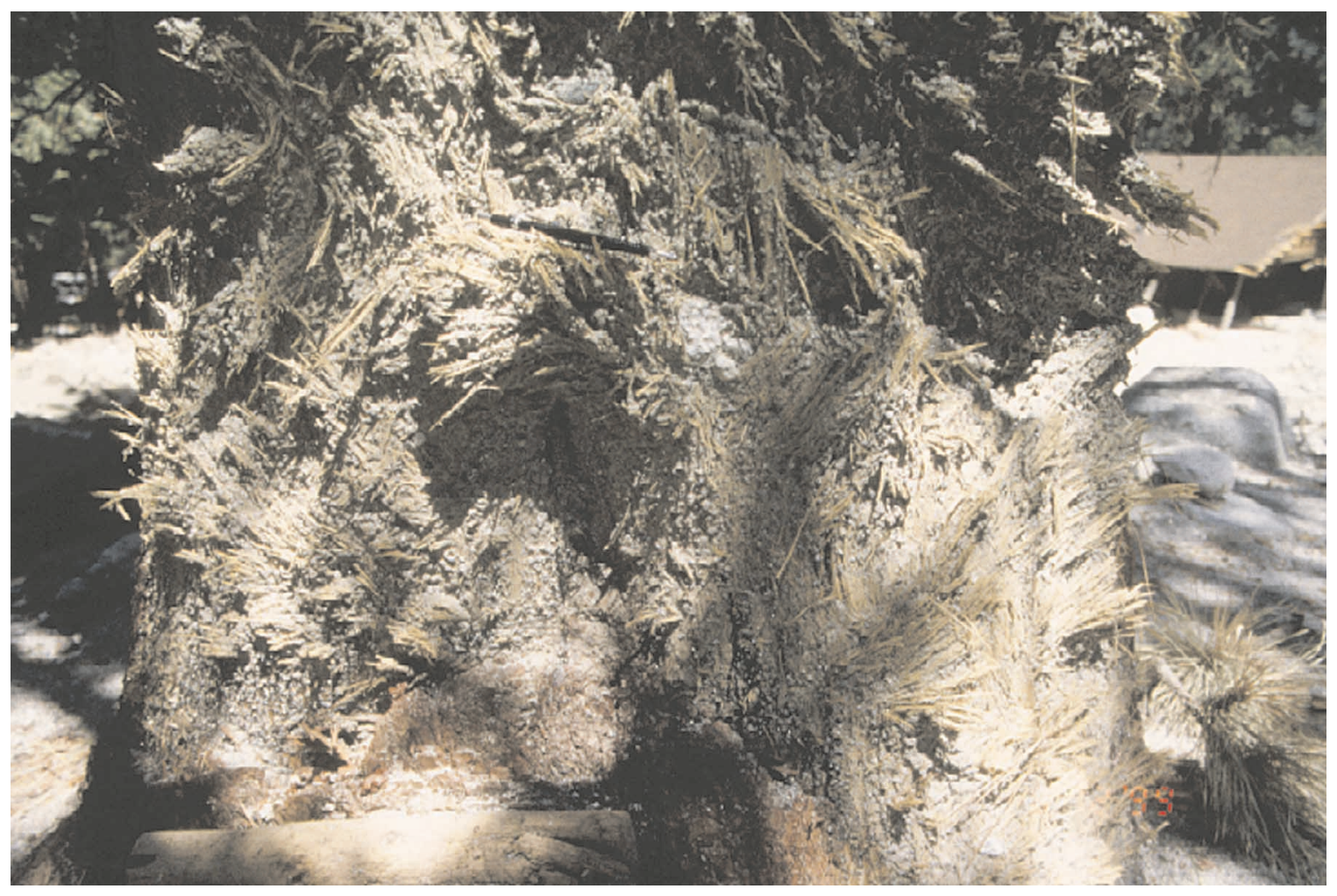

Figure 35. Upslope side of tree fragmented by the July 11, 1999, avalanche. Note the rock embedded in the fragmented wood below the right side of the pencil. 


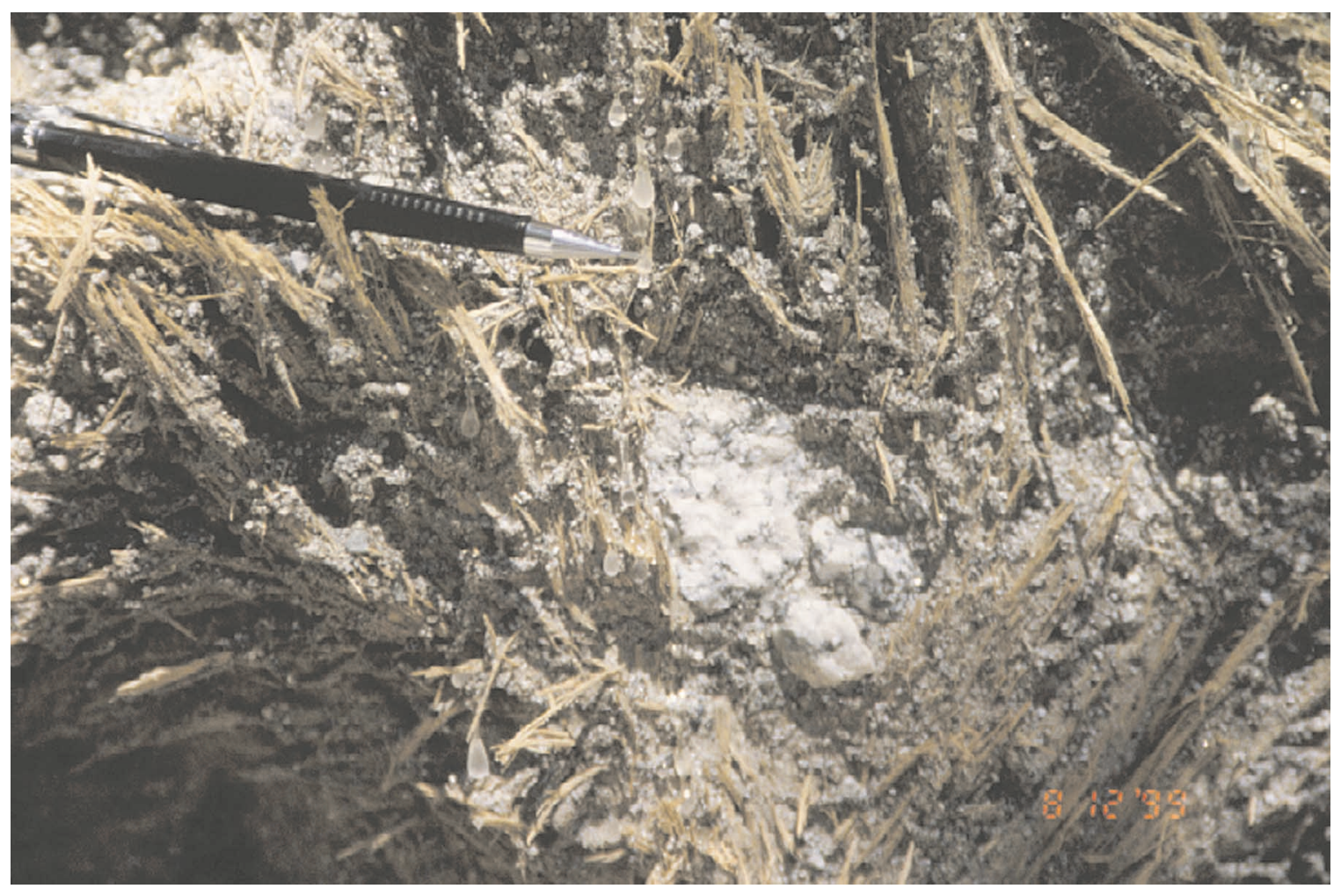

Figure 36. Rock embedded and fragmented by impact of the high velocity debris avalanche of July 11, 1999. 


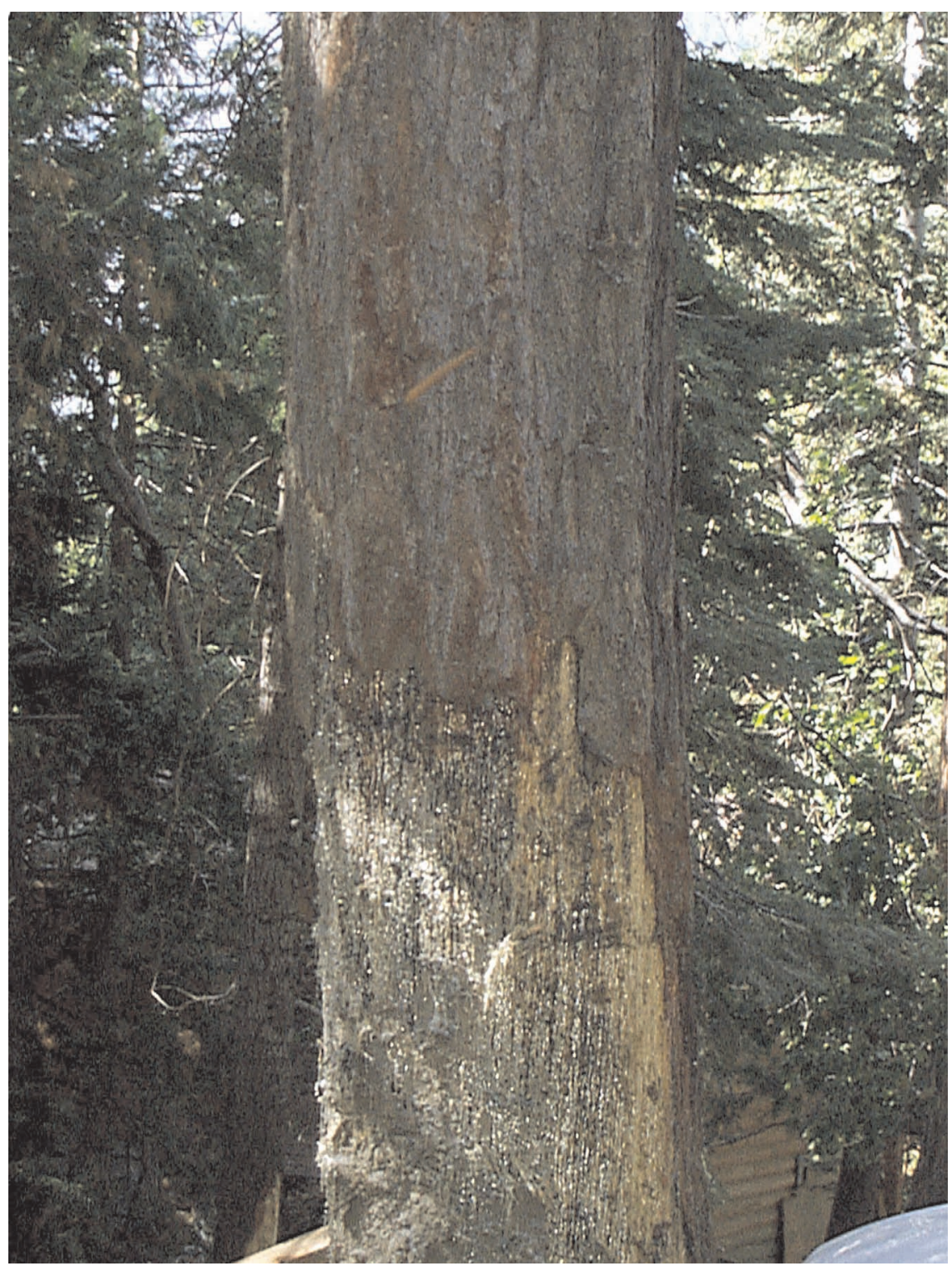

Figure 37. Wood splinter propelled by avalanche that was embedded in a tree about 300 feet below point where avalanche shot-over the channel. Height of the debris avalanche at this location, marked by the debarked side of the tree, was about 1.5 feet below the wood splinter. 


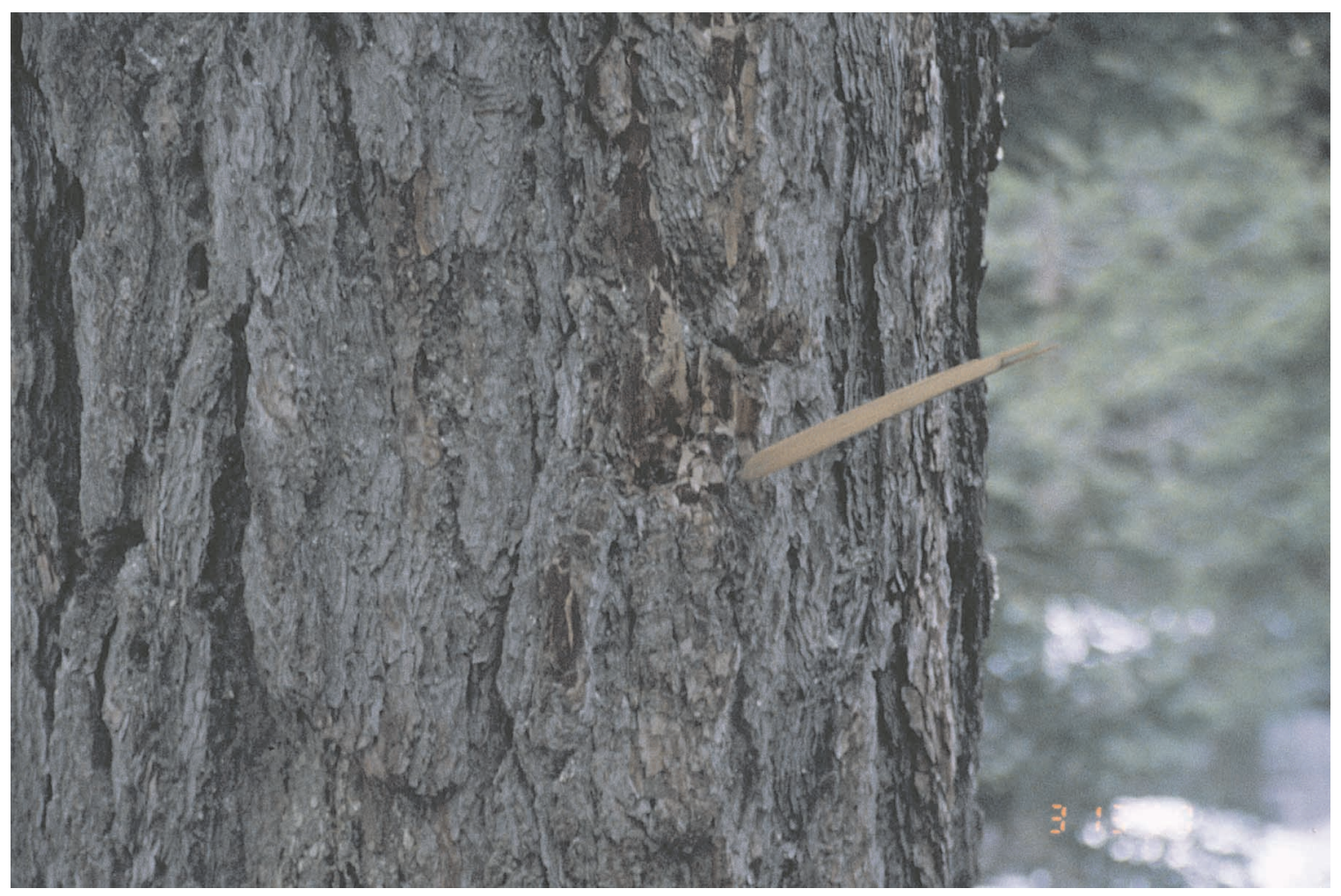

Figure 38. Close up of the wood splinter. Splinter is about nine inches in length. 


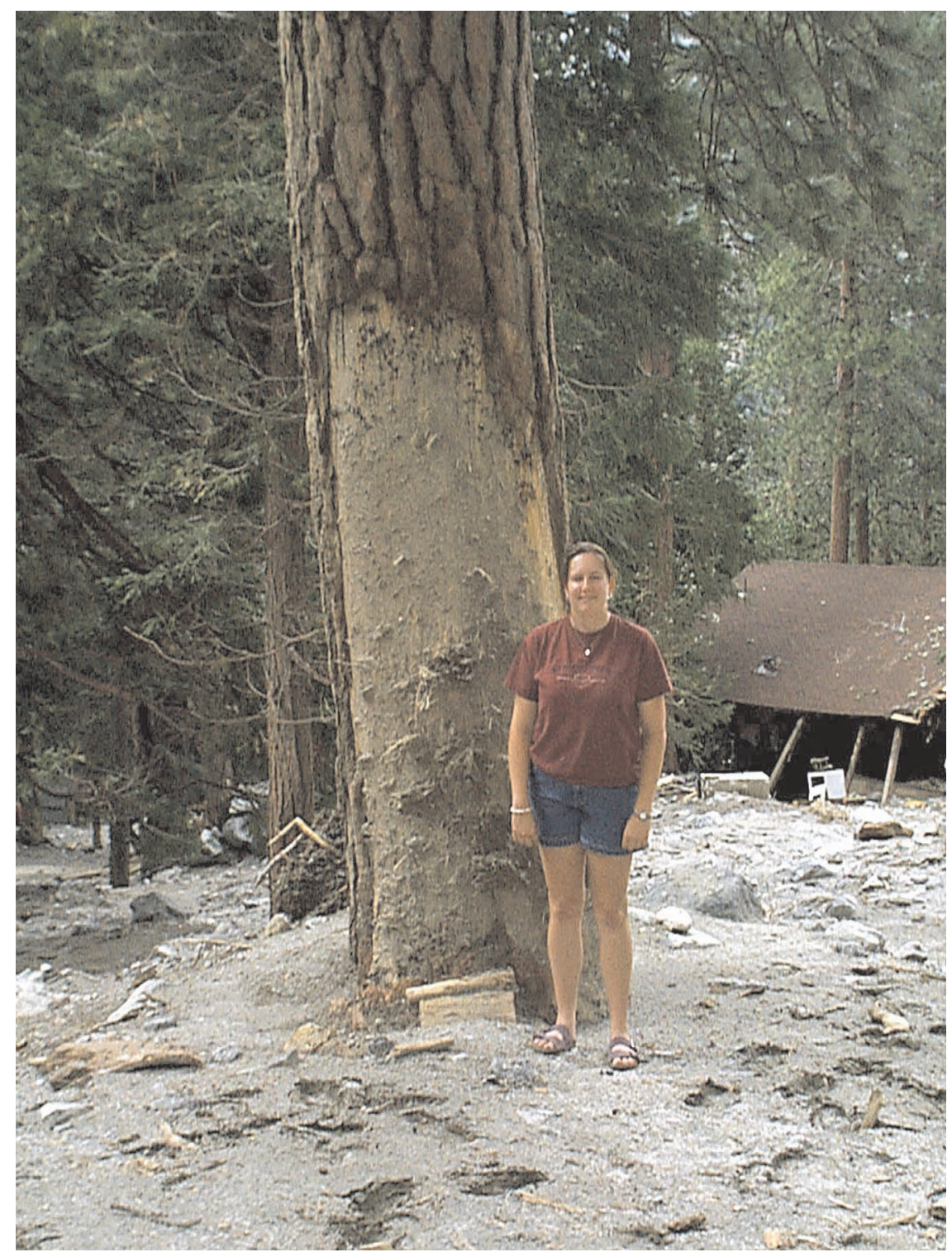

Figure 39. Tree scared by marginal part of the debris avalanche of July 11, 1999. This tree is located about 50 feet from the edge of the debris flow channel wall. Scar is eight feet above ground surface and mud was splattered ten feet above the scar. 


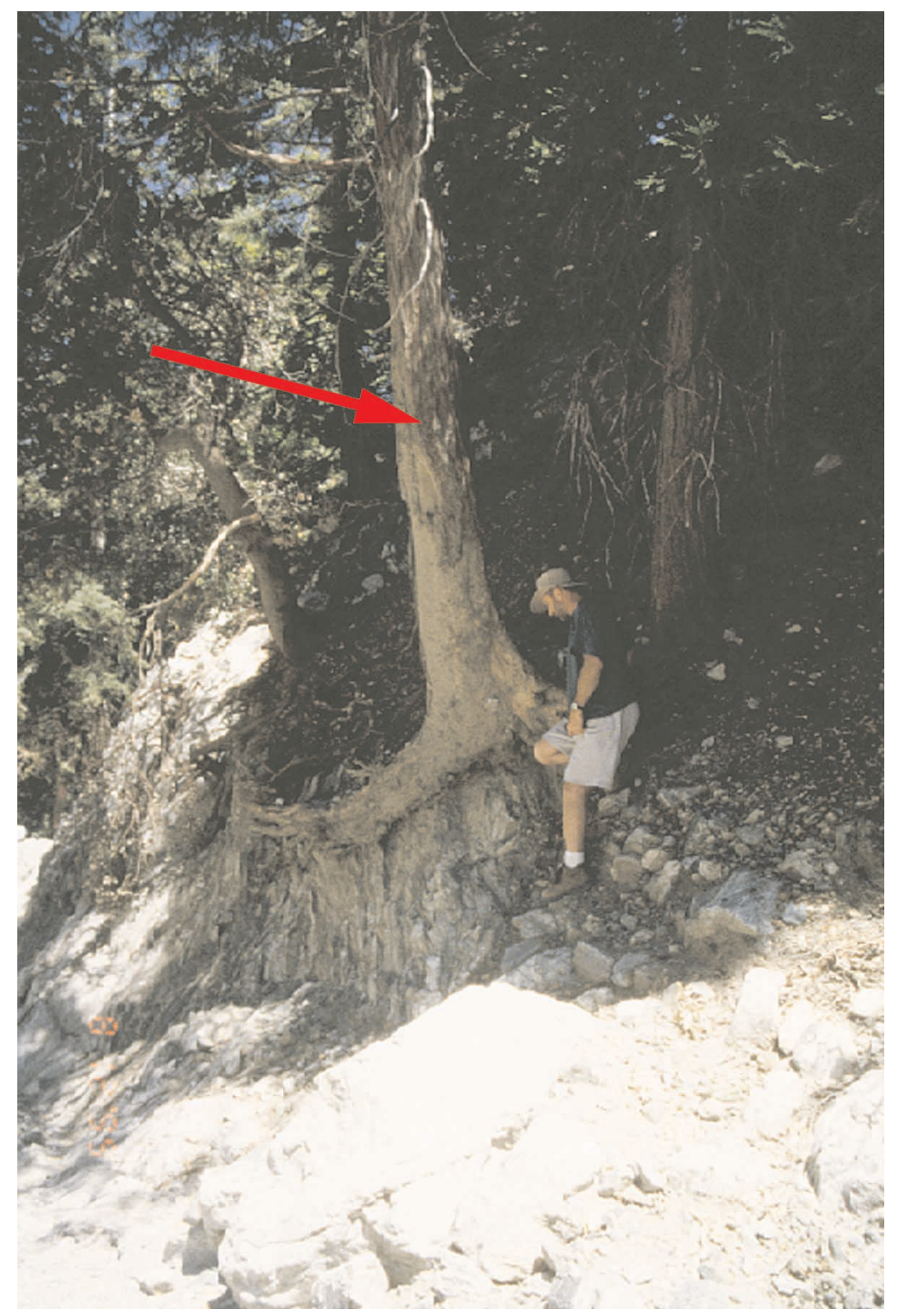

Figure 40. Tree scared on the high side of the superelevated avalanche. This tree is located on the outside of an open curve in the channel. The arrow points to the position where the avalanche scared the tree. Mud splattered to about eight feet above the scar. Note the avalanche did not extend to the right of the tree. 


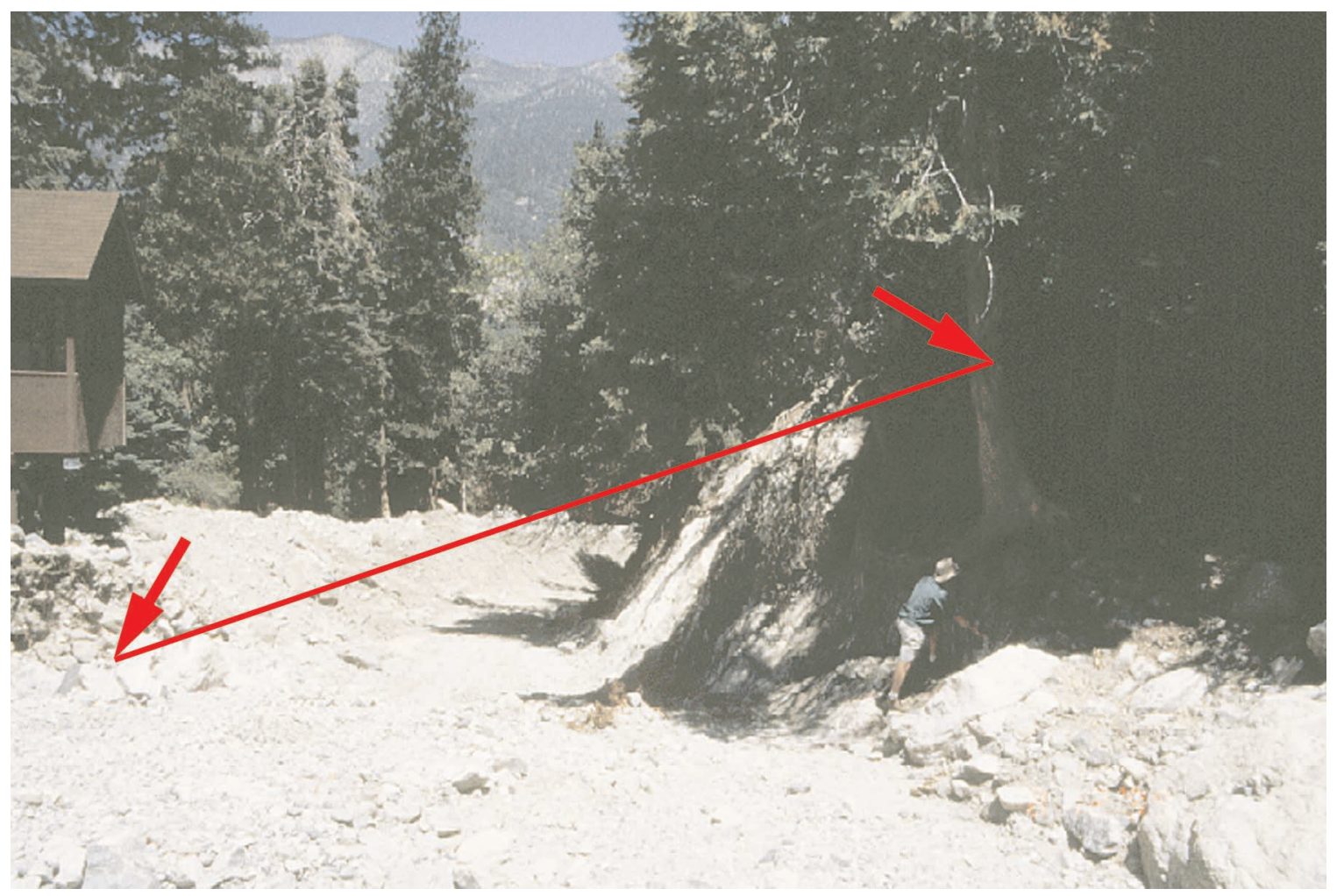

Figure 41. Arrow on the right side of the photograph is on tree is at the same position of the arrow on Figure 40. The arrow on the left side of the channel (below end of brown building) is the maximum elevation of the low side of the superelevated avalanche. The minimum elevation difference between the high and low side of the avalanche is 11 feet. This photograph was taken after the debris flows of July 13, 1999, and the arrow on the left side of the photograph probably is the height of the debris flows of July 13, 1999, rather than the debris avalanche of July 11. Thus the velocity determined for the debris avalanche at this site is a minimum velocity. 


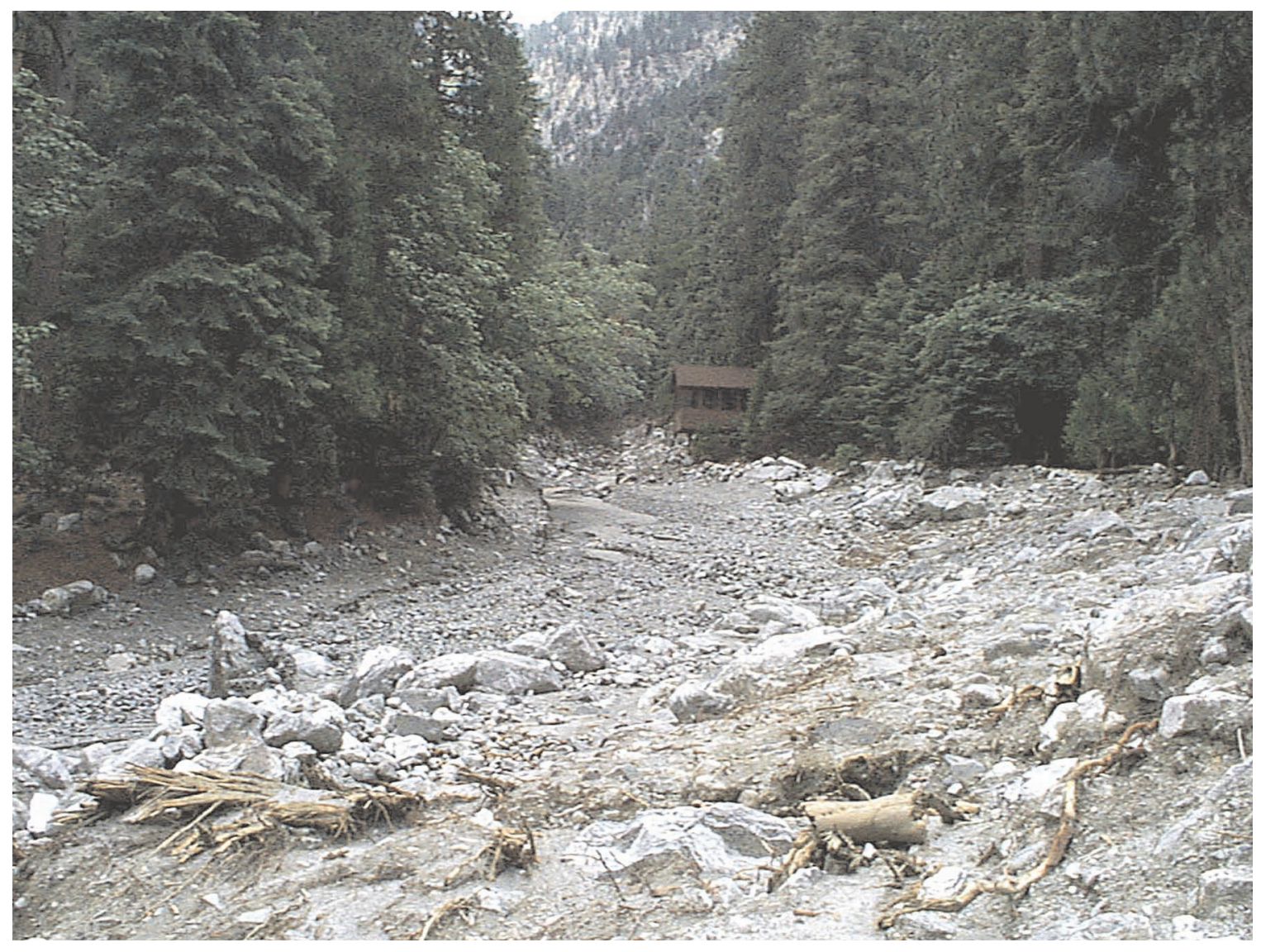

Figure 42. Curve in Snow Creek debris flow channel where avalanche shot over the channel wall. Note the 'swept' appearance of the degraded channel wall. Brown building in center of the photograph is that in the left side of Figure 41. Relative open curve in the channel to the left of the building is where the avalanche had a superelevation of a minimum of 11 feet. Photograph taken on July 12, 1999. 


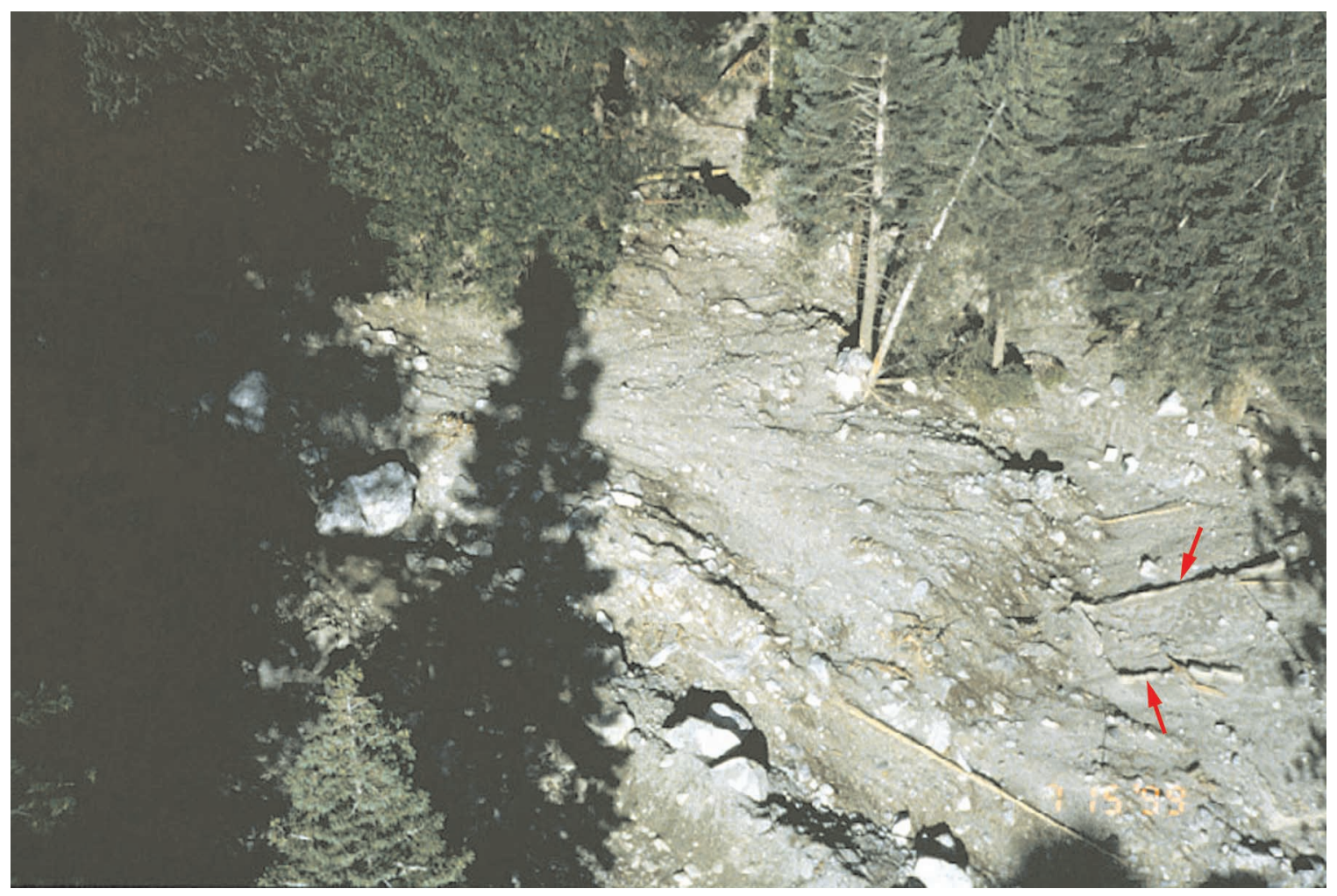

Figure 43. Surface of Snow Creek fan degraded by the debris avalanche where it shot over the channel wall. The rectangular area (arrows) is the foundation of the house completely destroyed and removed by the avalanche. The $1^{\text {st }}$ avalanche wave struck the end of the house at 90 degrees. The direction of the 1 st avalanche 'wave' is indicated by the flattened tree that is parallel to and just beyond the far side of the foundation. The fragments of the house are located to the right of the photograph parallel to the direction of length of the foundation and the flattened tree. The direction of the $2^{\text {nd }}$ and/or $3^{\text {rd }}$ avalanche 'waves' is indicated by the orientation of the flattened tree in the foreground. The new sharp-topped debris flow ridge was produced by 'overflow' from the debris flows of July 13 is seen in the center of the bottom of the photograph. Photograph taken on July 15, 1999. 


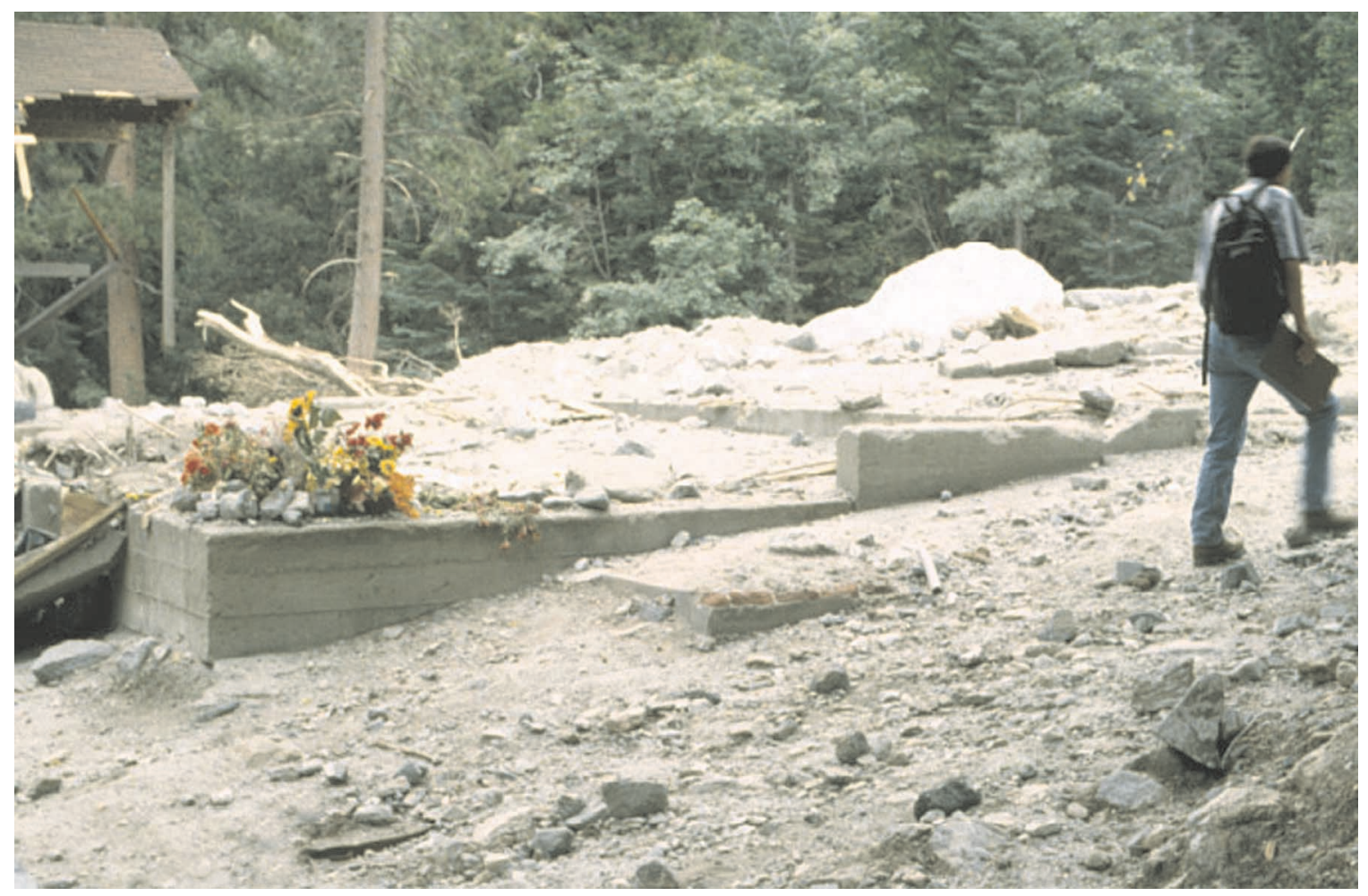

Figure 44. Battered foundation of the house that was destroyed and removed by the debris avalanche. 


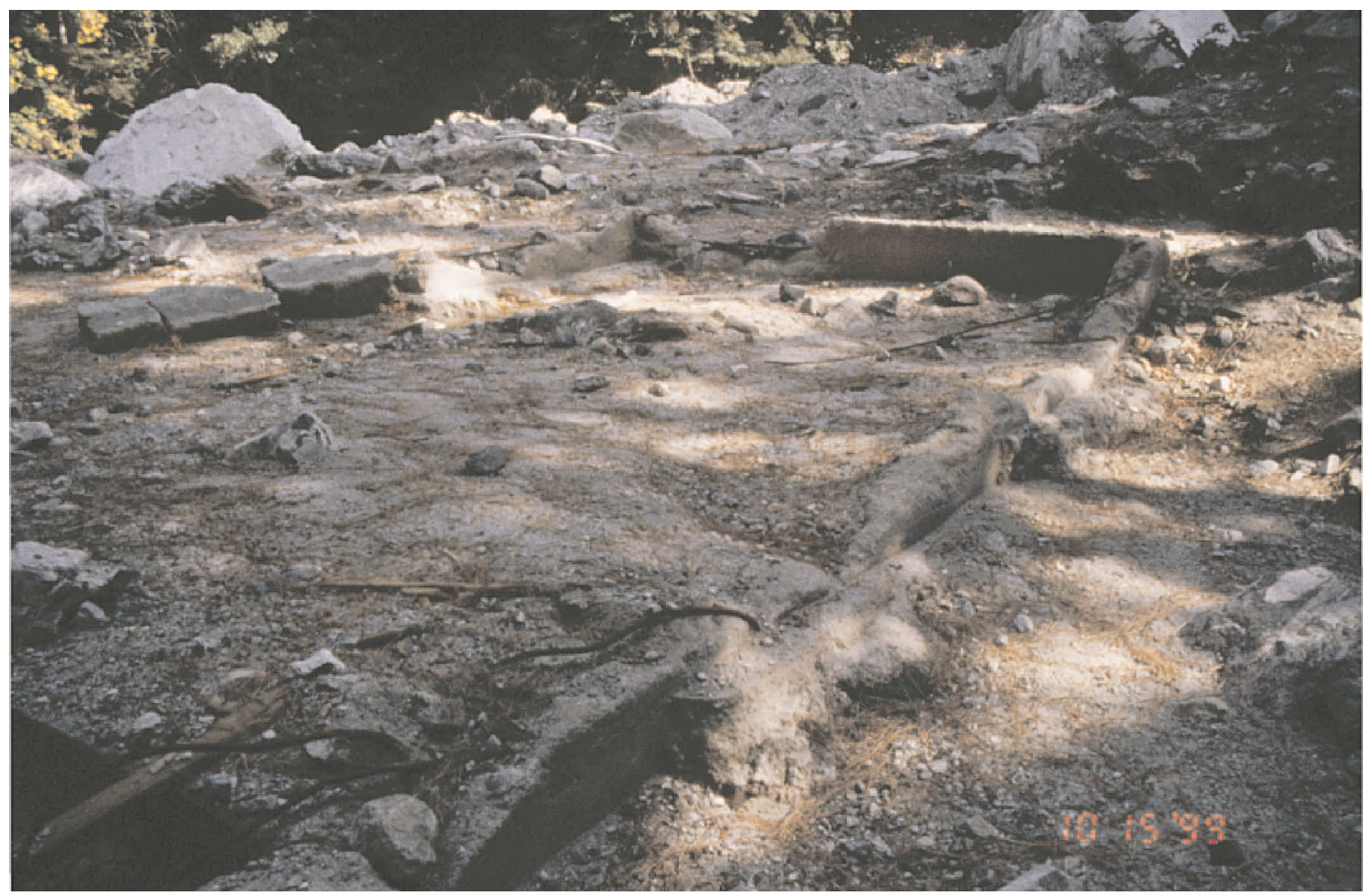

Figure 45. Close up of the foundation of the house. Note the fragmentation of the foundation and the reinforcing rods bent into the direction of flow of the debris avalanche. 


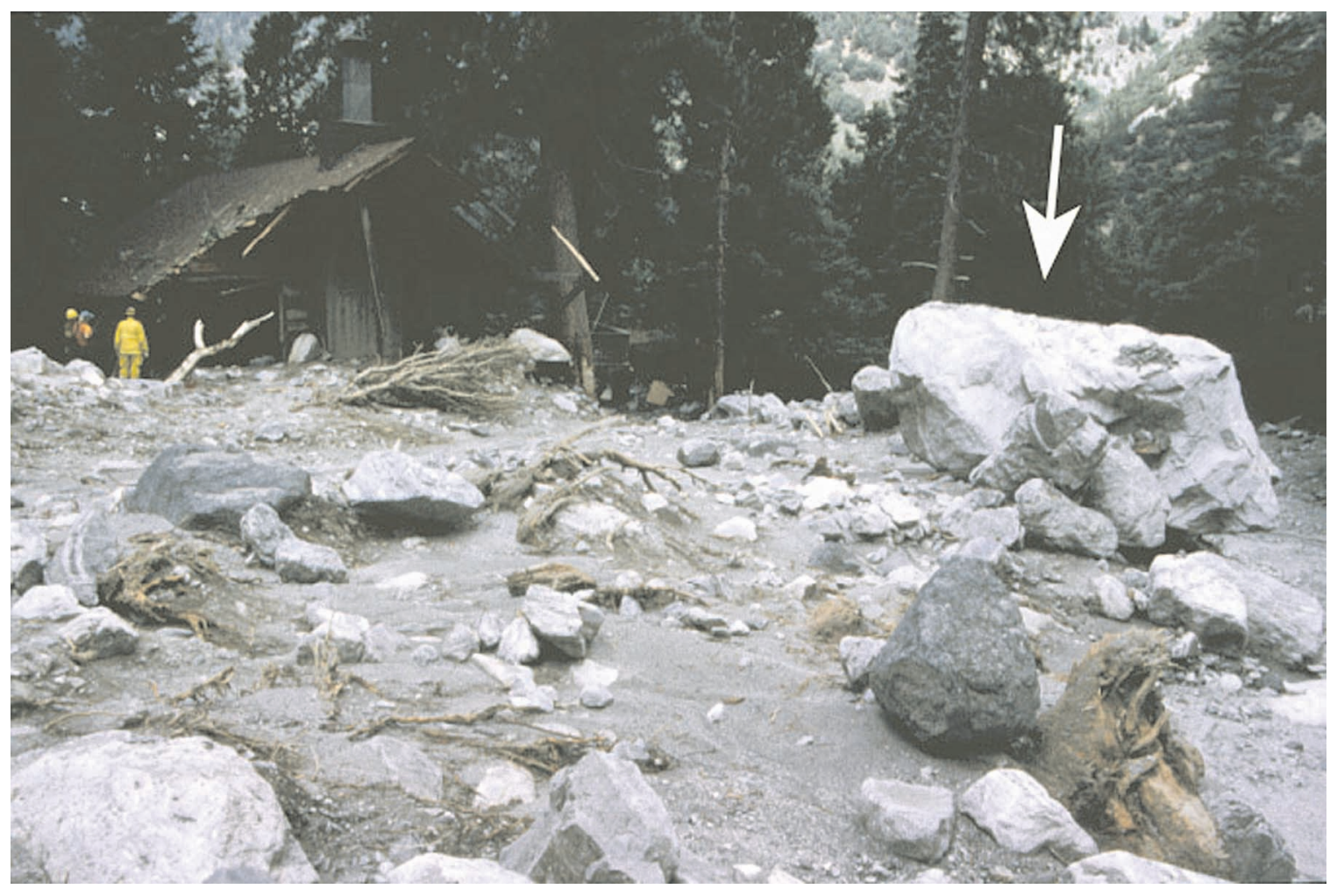

Figure 46. Swept landscape produced by the avalanche. Large boulder (arrow) moved in the avalanche is 16 feet in length (see Figure 21). Note the 'swept' appearance of the surface. House in background was struck on the left side by the $1^{\text {st }}$ 'wave' and the right side by the $2^{\text {nd }}$ and/or $3^{\text {rd } ~ ' w a v e ' . ~ P h o t o g r a p h ~ t a k e n ~}$ July 12, 1999. 


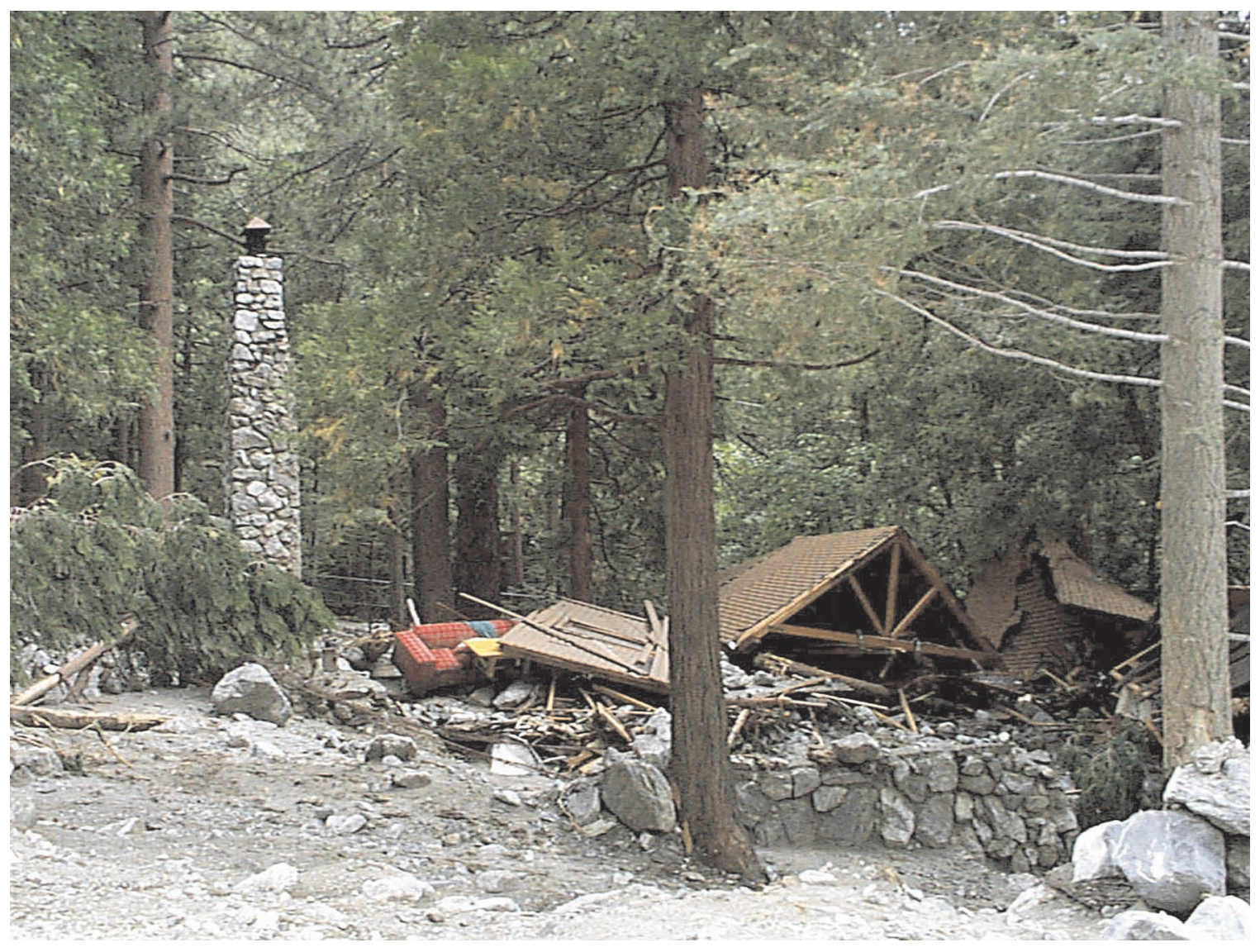

Figure 47. Houses destroyed by the first debris avalanche wave on the west side of the avalanche. Photograph taken July 12, 1999. 


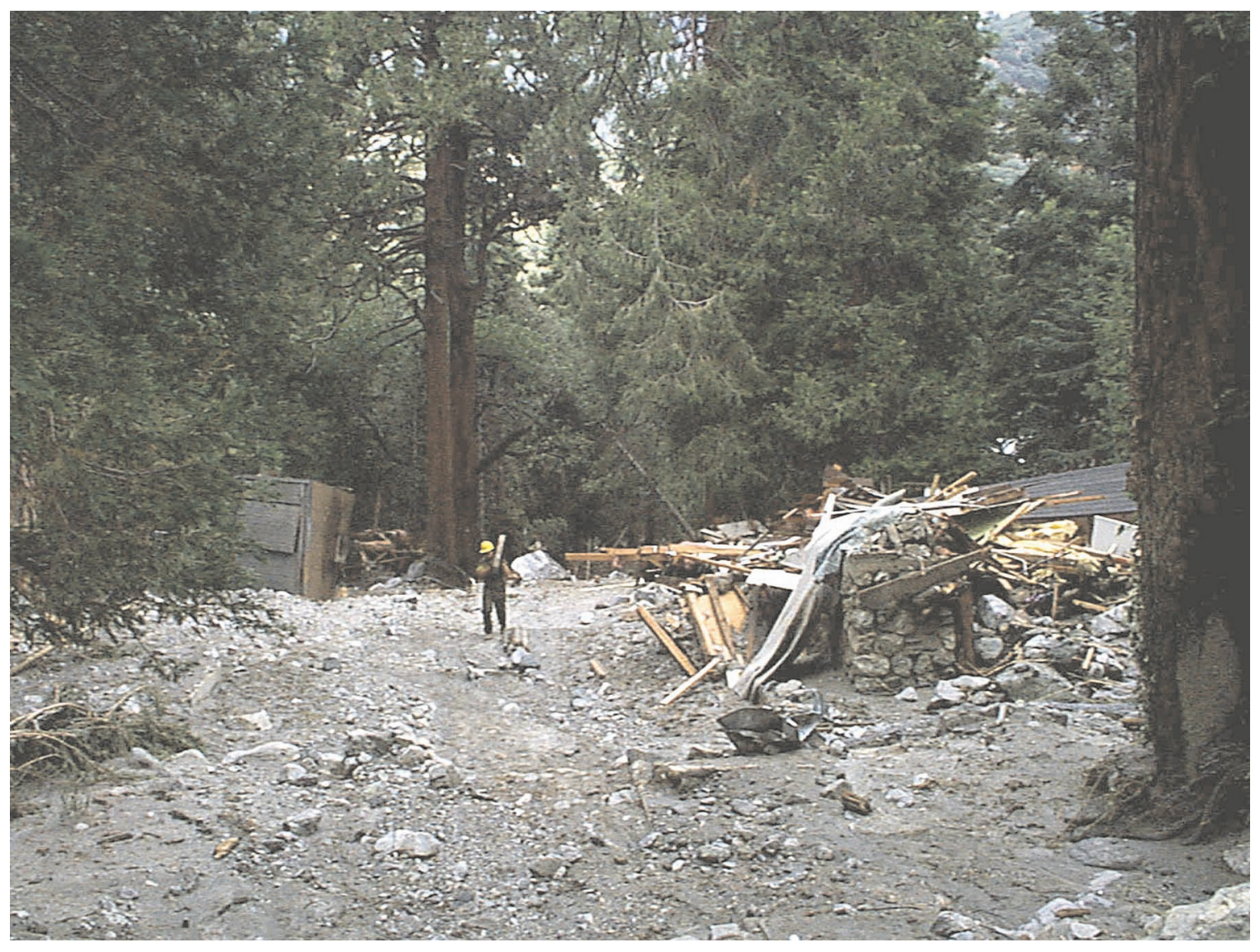

Figure 48. Destroyed houses down Snow Creek fan along the central path of the first debris avalanche wave. Here the debris avalanche, no longer confined by a channel had spread out over a width of more than 100 feet. Photograph taken July 12, 1999. 


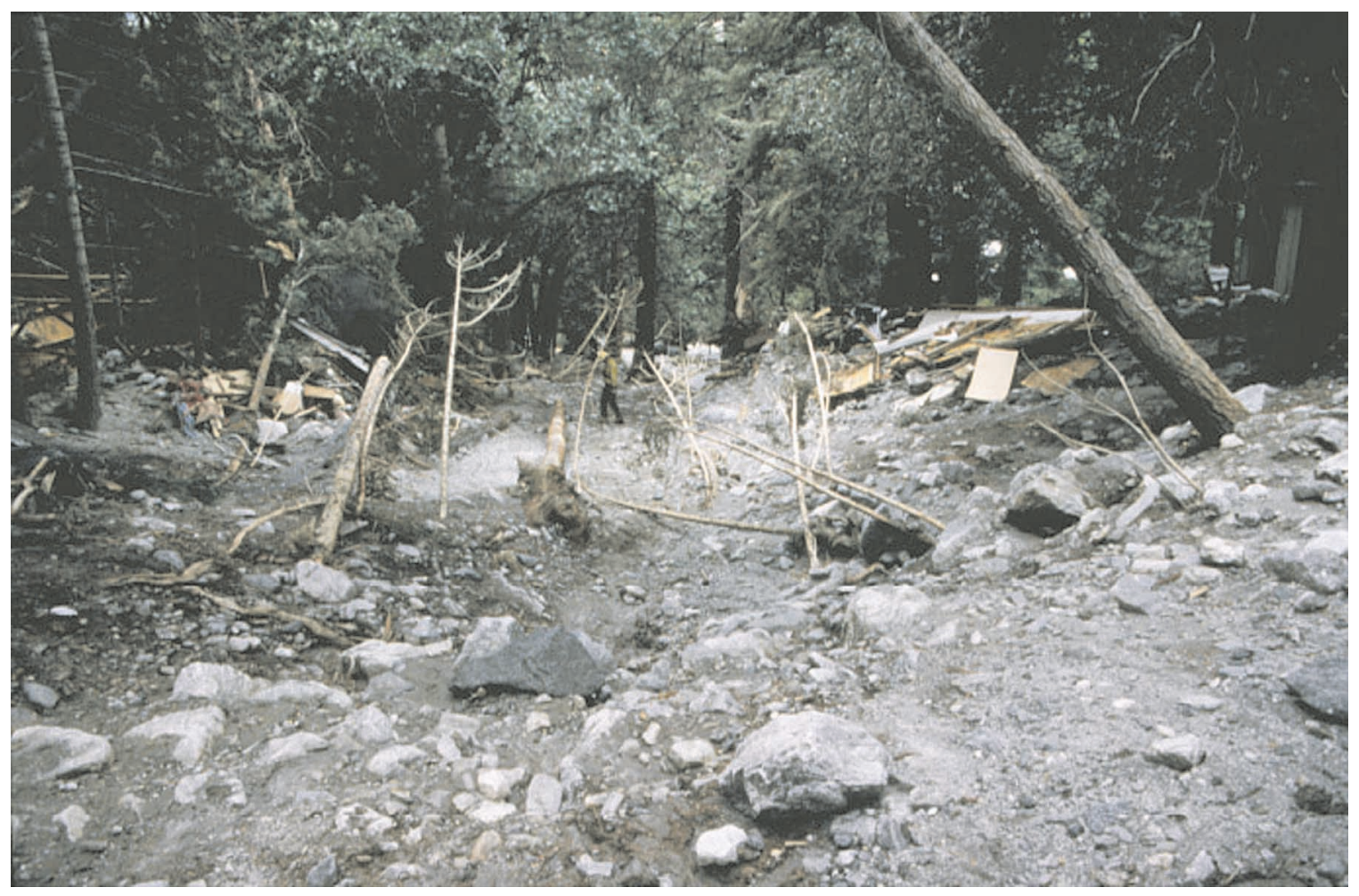

Figure 49. Destruction of structures in the path of the $1^{\text {st }}$ and perhaps $2^{\text {nd }}$ avalanche 'waves' as the debris descended down Snow Creek fan. This location down fan from the location of Figure 47. Note the bent and stripped small pine trees oriented parallel to the flow direction of the avalanche. Although the avalanche was slowing it still retained considerable energy. Photograph taken July 12, 1999. 


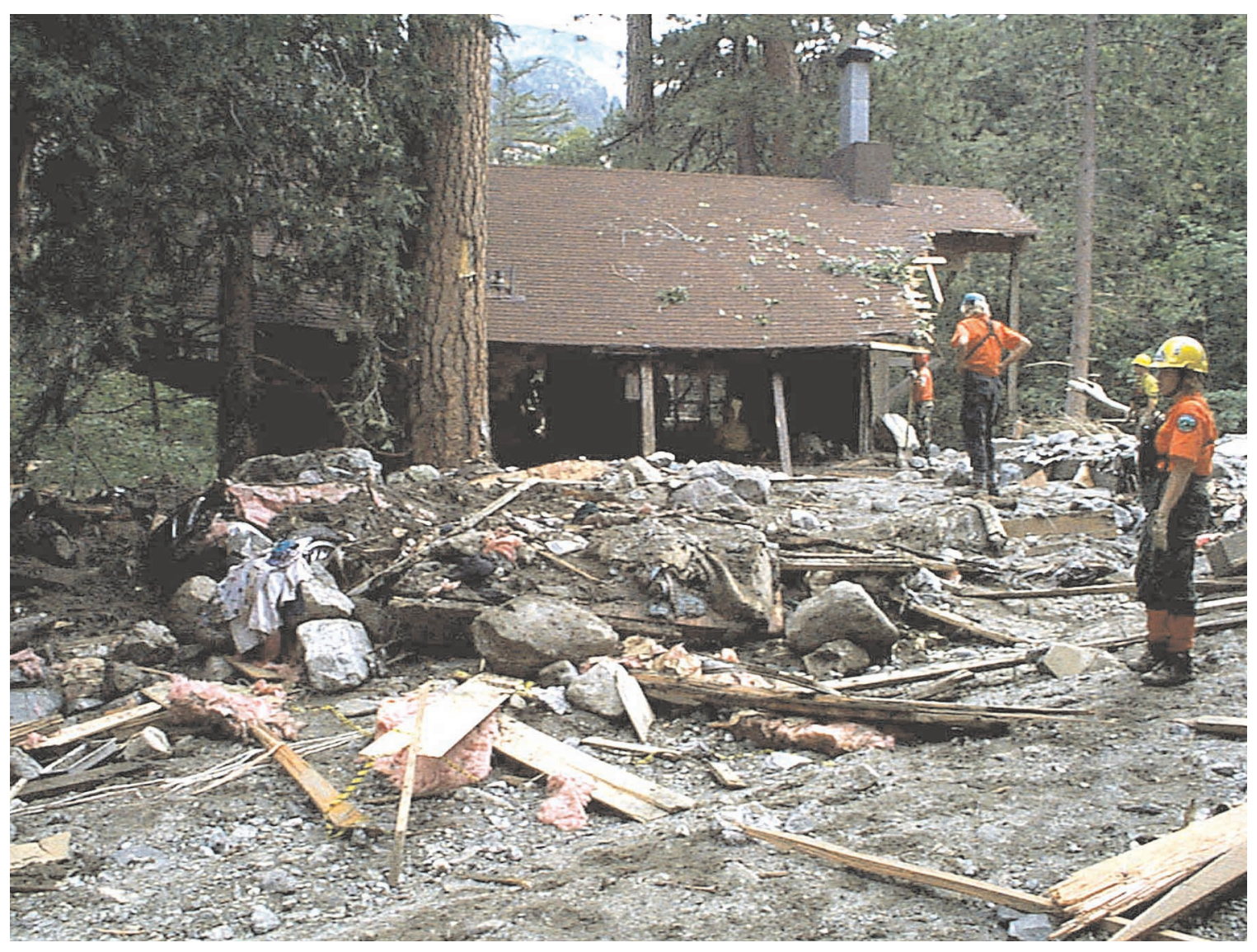

Figure 50. Two cars flattened by the debris avalanche are partly exposed in the mixture of rock and house debris. Note the scar on the large pine tree produced by debris 'thrown' by the debris avalanche (see Figure 55 for detailed photograph of the scar). Photograph taken July 12, 1999. 


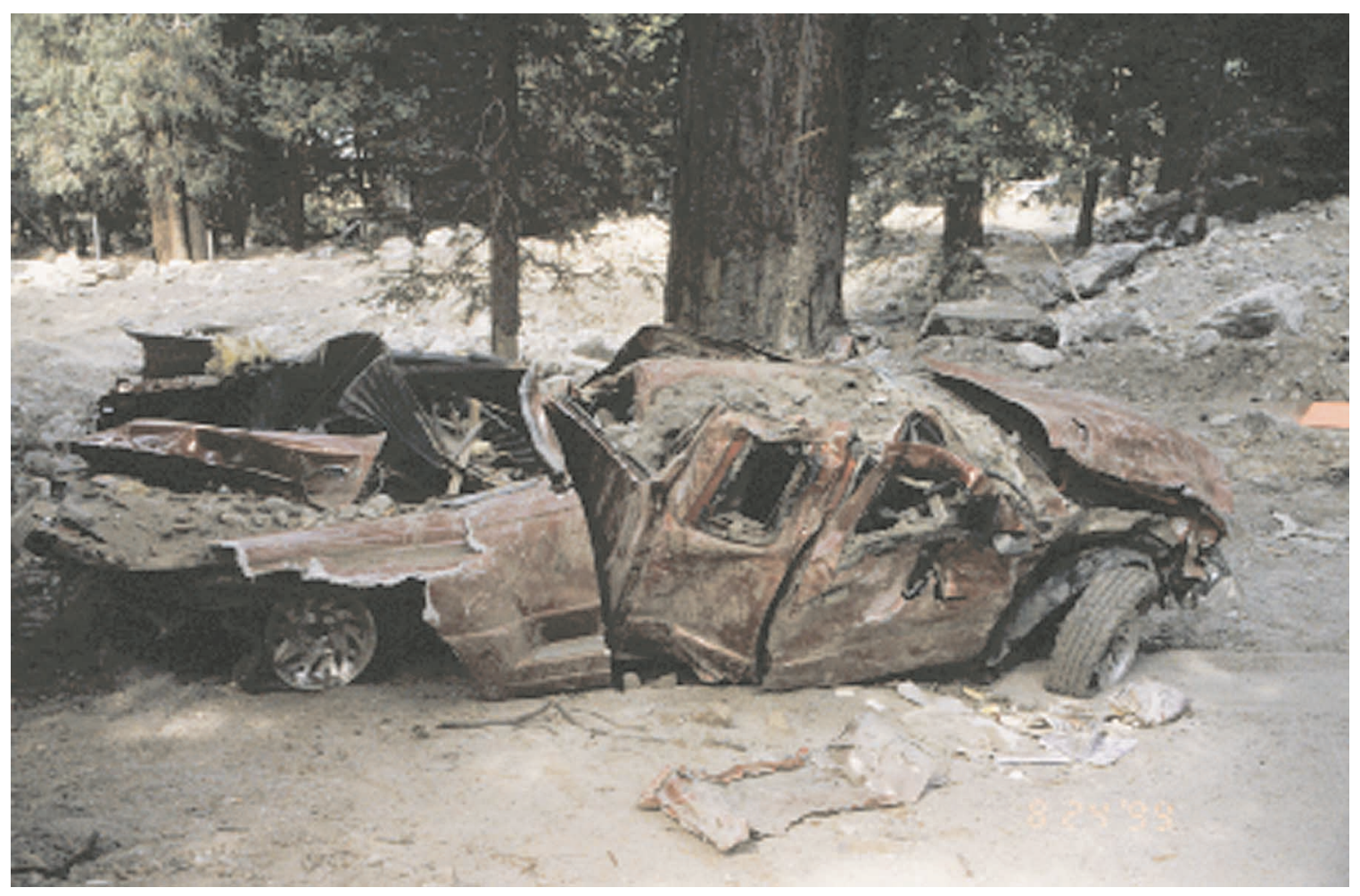

Figure 51. Car exhumed from the site of Figure 50. 


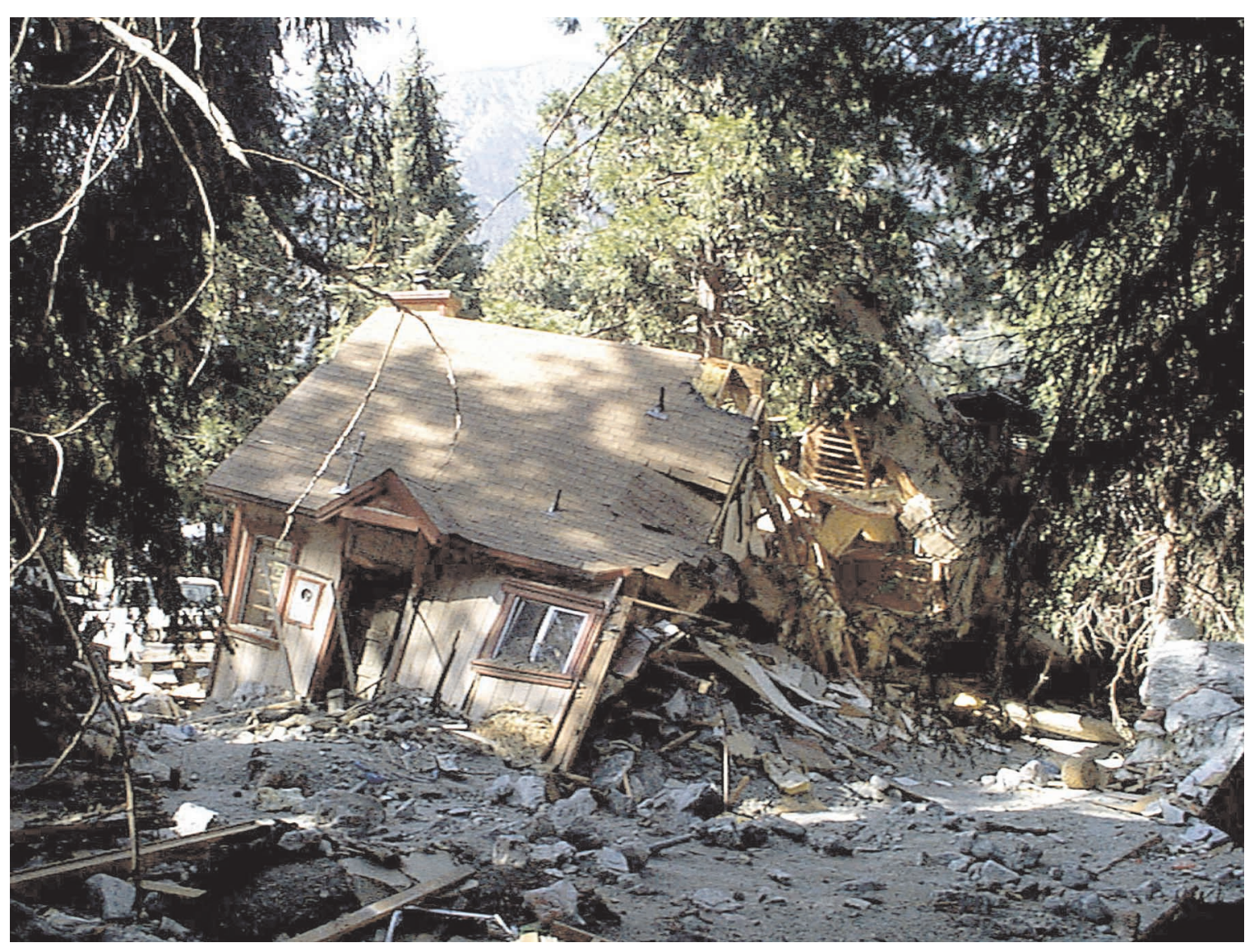

Figure 52. Damage to structures produced down fan on the east side of the $3^{\text {rd }}($ ?) wave of the debris avalanche. 


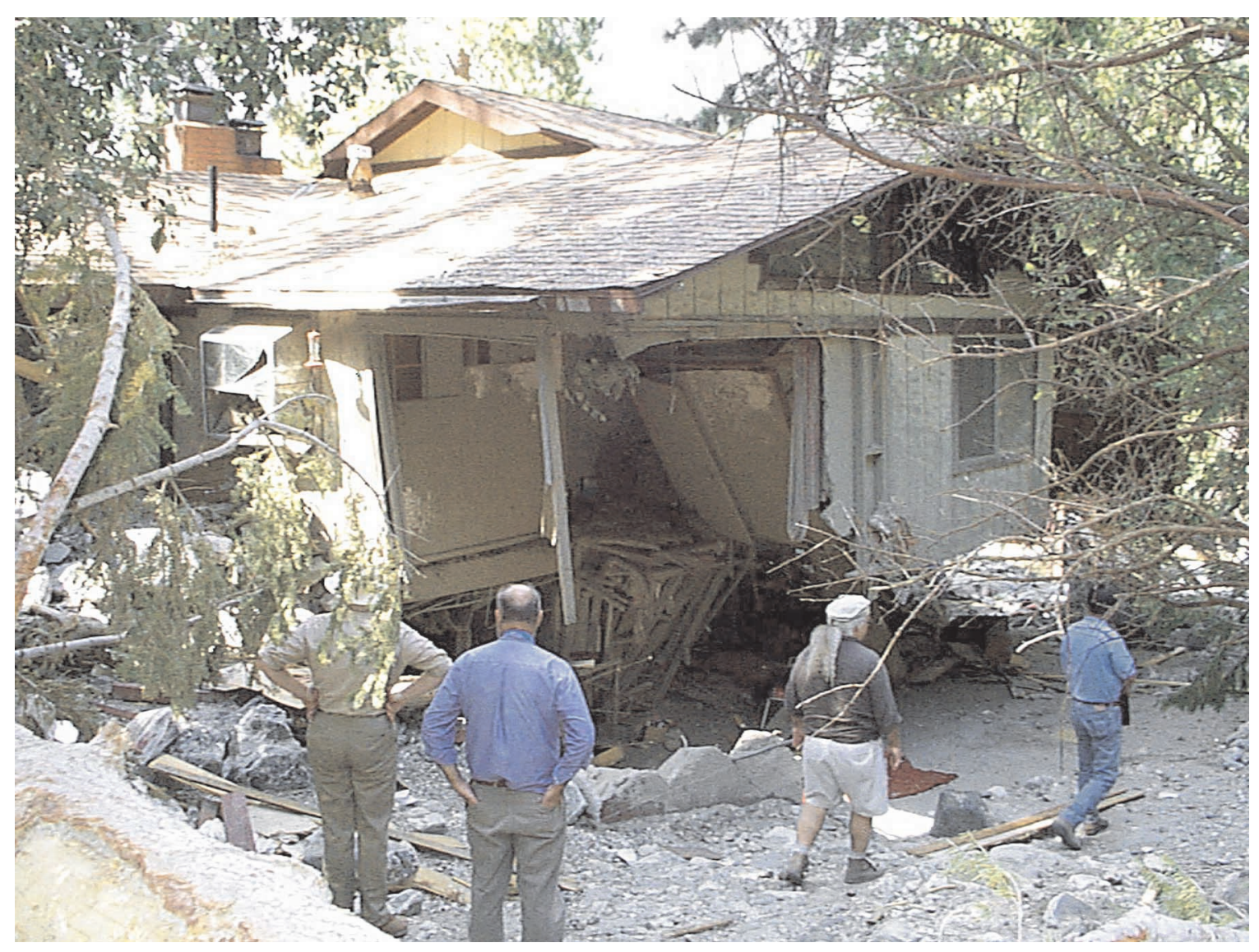

Figure 53. Damage to structures produced down fan on the east side of the $3^{\text {rd }}($ ?) wave of the debris avalanche. Note the fragmented foundation in the foreground. 


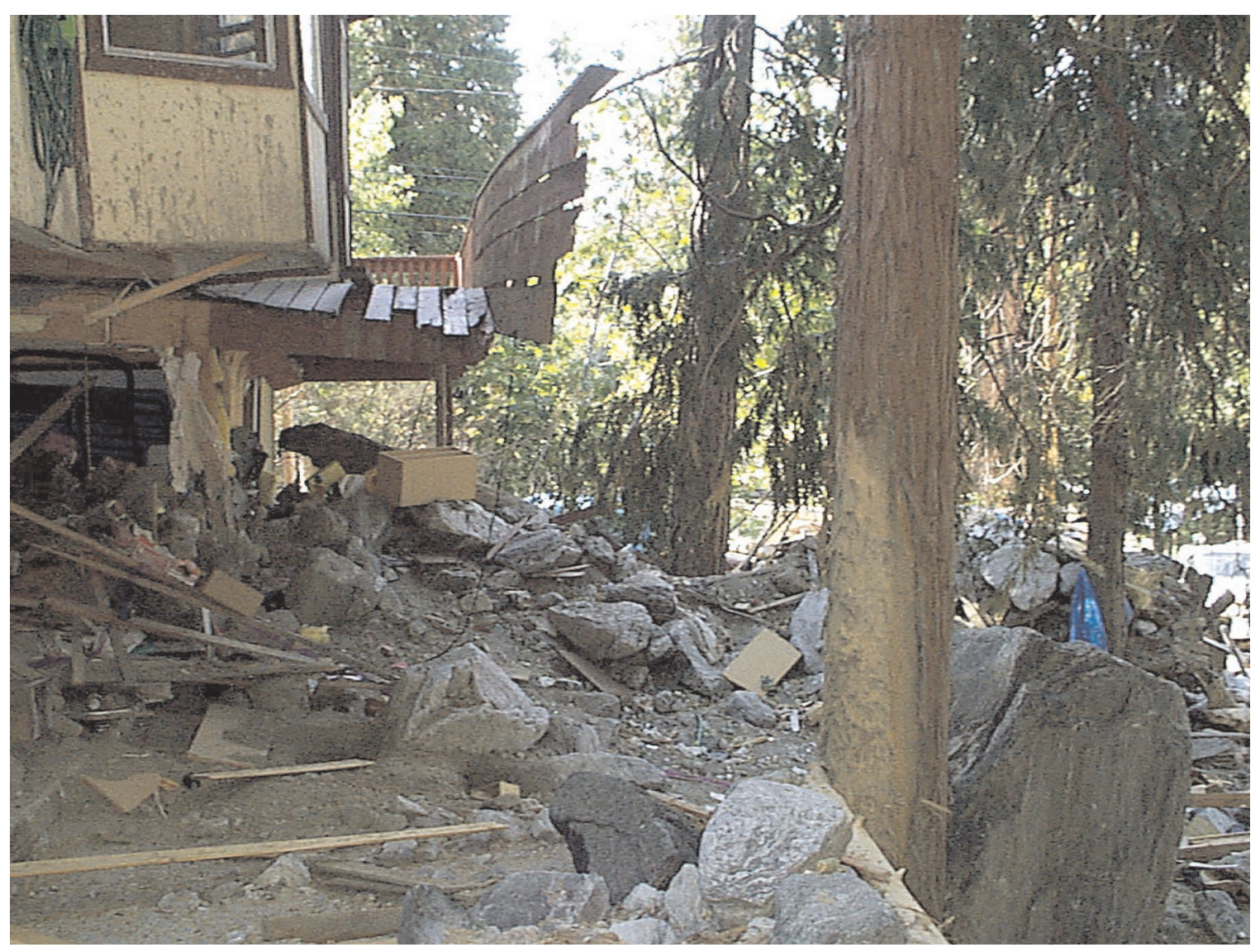

Figure 54. Damage to structures produced down fan at the east edge of the $3^{\text {rd }}(?)$ wave of the debris avalanche. Note the scaring on the left side of tree in the foreground. 


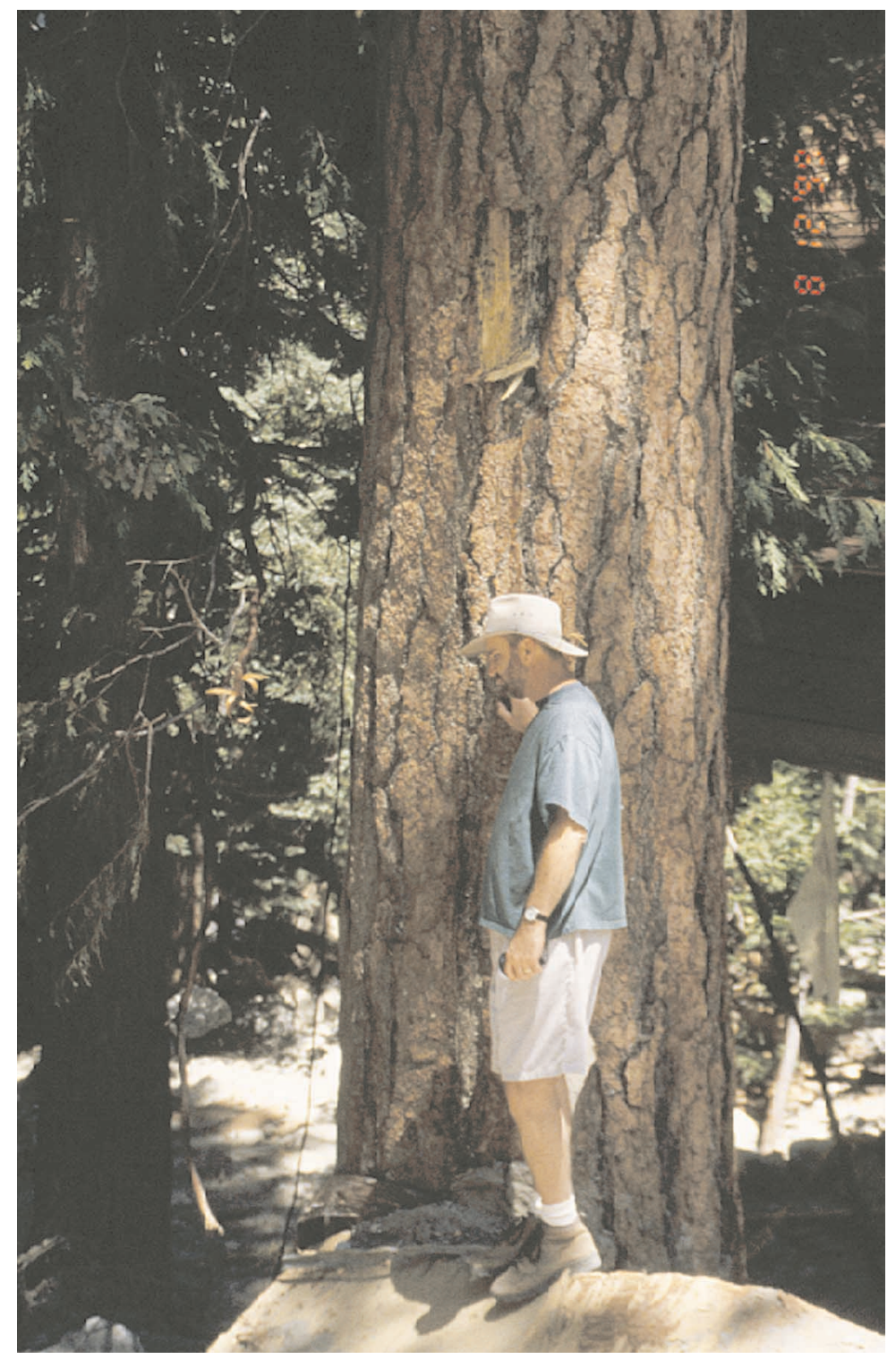

Figure 55. Scar produced by a thrown rock eight feet above the surface of the avalanche. 


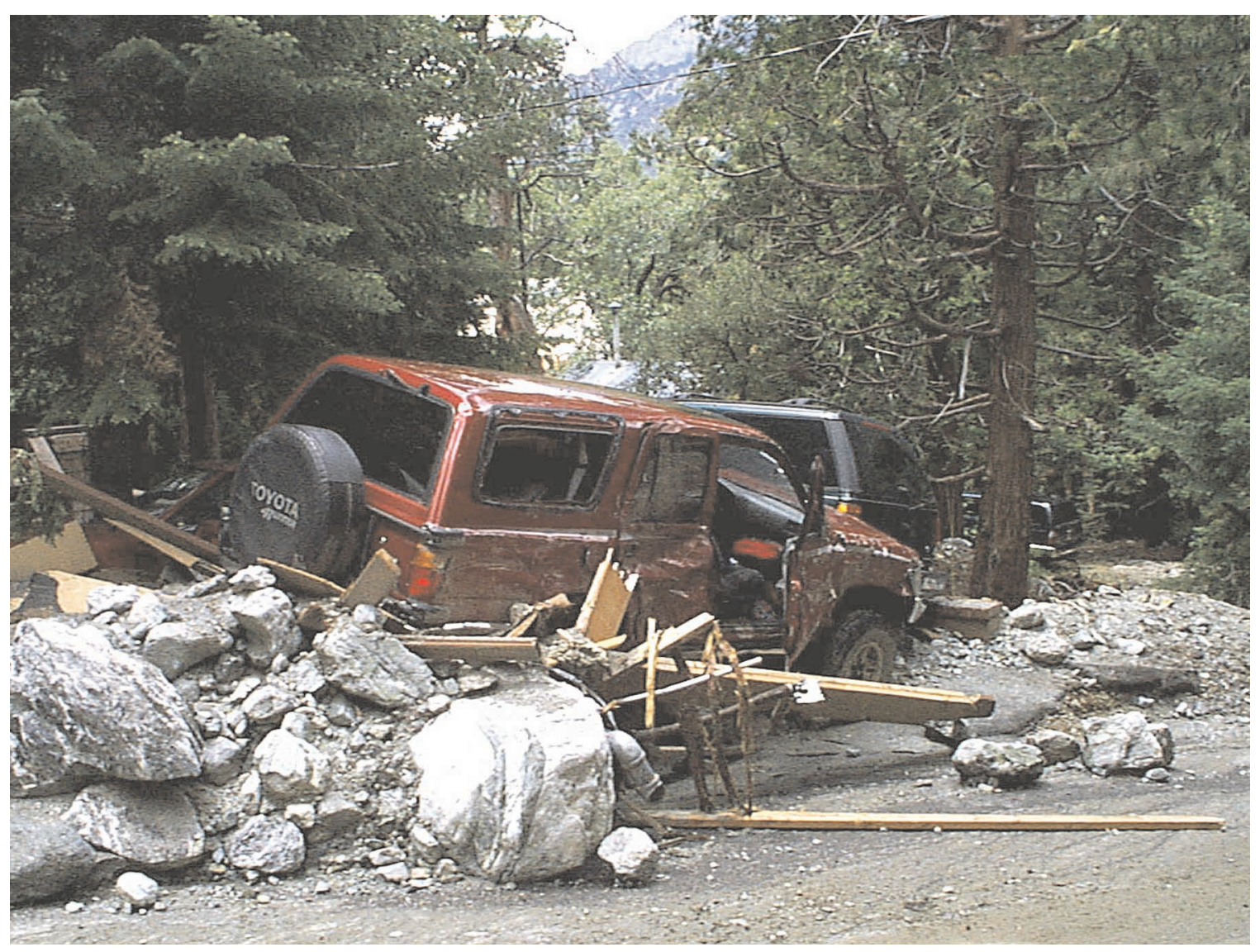

Figure 56. Damage where the $3^{\text {rd }}($ ?) wave of the debris avalanche spread-out down fan and was loosing velocity. Note the relatively clean nature of the deposit. 


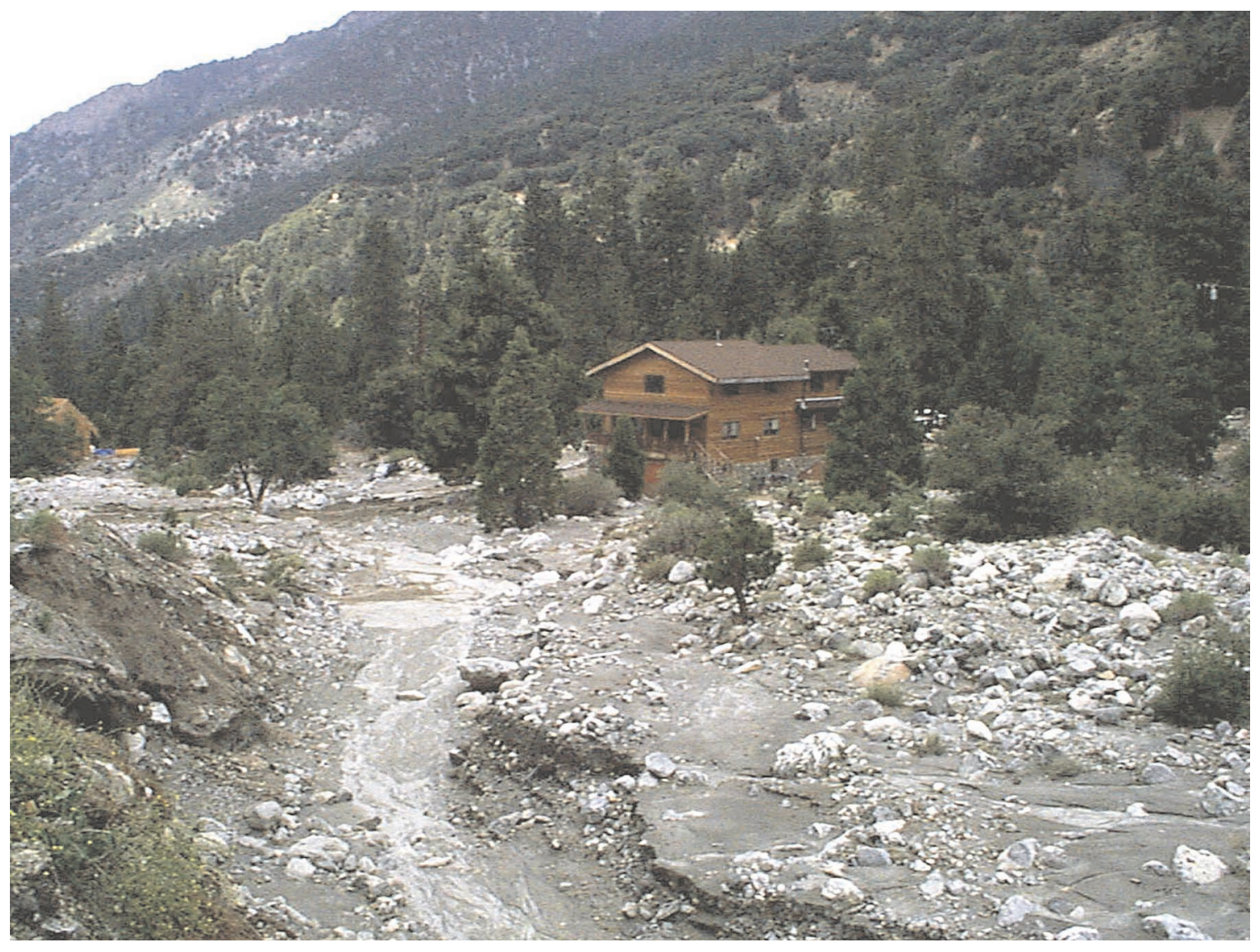

Figure 57. Fluvial deposits in the main channel of Mill Creek. Note the rounded nature of the clasts in contrast to the angular clasts in the debris flow and debris avalanche deposits. 